\title{
Article
}

\section{Nepheline solid solution compositions: stoichiometry revisited, reviewed, clarified and rationalised}

\author{
C. Michael B. Henderson (i) \\ Emeritus Professor, School of Earth and Environment Sciences (SEES), University of Manchester, Manchester M13 9PL, UK
}

\begin{abstract}
Molecular formulae used to recalculate nepheline analyses generally have different numbers of oxygens (e.g. $\mathrm{NaAlSiO}_{4}(\mathrm{Ne}), \mathrm{KAlSiO}_{4}$, (Ks), $\mathrm{CaAl}_{2} \mathrm{Si}_{2} \mathrm{O}_{8}(\mathrm{An})$ and $\left.\mathrm{SiO}_{2}(\mathrm{Q})\right)$. A 32 oxygen cell has $16 \mathrm{~T}$ cations and 8 cavity sites, but ideal nepheline stoichiometry is not necessarily followed. Ca end-member $\square^{\mathrm{Ca}} \mathrm{CaAl}_{2} \mathrm{Si}_{2} \mathrm{O}_{4}(\mathrm{CaNe})$ and excess silica end-member $\square^{\mathrm{Si}} \mathrm{Si}_{2} \mathrm{O}_{4}$ (Q') calculation requires inclusion of both vacancy species as cavity cation values. Q' parameter calculations can involve different assumptions and four parameters are described: $\mathrm{Q}^{\mathrm{xs}} ; \mathrm{Q}^{\mathrm{Si}} ; \mathrm{Q}^{(\mathrm{Si}-\mathrm{Al})}$; and $\mathrm{Q}^{\text {cavity }}$; these should have closely similar values for high-quality, stoichiometric analyses.

Representative published compositions are recalculated to assess whether authors followed ideal nepheline stoichiometry. Phenocrysts

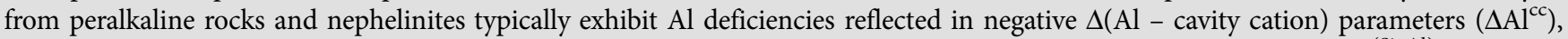
negative 'normative' corundum $\left(\mathrm{Al}_{2} \mathrm{O}_{3}, \mathrm{Cn}\right)$, and anomalously low or negative $\mathrm{Q}^{\mathrm{xs}}$ parameters; for such rock types $\mathrm{Q}^{(\mathrm{Si}-\mathrm{Al})}$ provides a better estimate of excess silica contents. A $\Delta \mathrm{T}$-site (cation charge) parameter $\left(\Delta \mathrm{T}^{\text {charge }}\right)$, is closely coupled to $\Delta \mathrm{Al}{ }^{\mathrm{cc}}$ and end-member $\mathrm{NaAlSiO}_{4}$ has a $\Delta \mathrm{Al}^{\mathrm{cc}} / \Delta \mathrm{T}^{\text {charge }}$ ratio of 1.4296 ; the derivation of this value is controlled by strict stuffed-tridymite, unit-cell constraints. Natural nephelines all contain excess silica with a mean $\Delta \mathrm{Al}^{\mathrm{cc}} / \Delta \mathrm{T}^{\text {charge }}$ of $\sim 1.134$ reflecting their Si/Al ratio being $>1$.

Nepheline analyses with relatively low $\mathrm{Al}$ and $\mathrm{Si}$ and high $\mathrm{Na}$ (also $\mathrm{Ca}$ ) contents are common; this might reflect the presence of small amounts (up to $\sim 5 \%$ ) of cancrinite as an alteration phase or perhaps even in solid solution. The compositions of alteration lamellae of Ca-rich cancrinite in altered nepheline phenocrysts in phonolites from the Marangudzi alkaline complex, Zimbabwe, are used to define diagnostic parameters for recognising such non-stoichiometry. These alteration lamellae formed hydrothermally from Ca-rich and Kpoor fluids.
\end{abstract}

An EXCEL file is provided to help researchers to standardise calculation of nepheline end-member molecular proportions.

Keywords: nepheline stoichiometry, stuffed-tridymite constraints, end-member calculations, coupled $\Delta \mathrm{Al}^{\text {cavity }}$ cations and $\Delta \mathrm{T}^{\text {charge }}$ parameters, criteria for analysis acceptability

(Received 10 July 2020; accepted 13 October 2020; Accepted Manuscript published online: 9 November 2020; Associate Editor: Ian Coulson)

\section{Introduction}

While preparing a paper on the mineralogy of differentiated rocks in the Marangudzi sub-volcanic syenite complex, Zimbabwe, it became clear that different authors use different calculation procedures to consider the compositional variations for nepheline. Most authors now use a 32 oxygen basis equivalent to the unit cell that contains 8 formula units of the fundamental nepheline end-member $\mathrm{NaAlSiO}_{4}(\mathrm{Ne})$; however, calculating values for chosen end-member molecular 'mineral' formulae is where differences emerge.

In a seminal paper Tilley (1954; but also see 1958 and Tilley and Gittins, 1961) reported classical wet-chemical analyses of nephelines from various alkaline rocks and recalculated analysed

\footnotetext{
Author for correspondence: C. Michael B. Henderson, Email: michael.henderson@ manchester.ac.uk

This paper is dedicated to my friends, colleagues and collaborators D.L. Hamilton (Dave), W.S. MacKenzie (Mac), J.V. Smith (Joe) and J.B. Dawson (Barry) all of whom had died before I got really interested in nepheline stoichiometry; I needed to talk to them about all the 'wrinkles' posed by this challenging topic.

Cite this article: Henderson C.M.B. (2020) Nepheline solid solution compositions: stoichiometry revisited, reviewed, clarified and rationalised. Mineralogical Magazine 84, 813-838. https://doi.org/10.1180/mgm.2020.78
}

oxide components in terms of the end-member mineral molecules: nepheline $\left(\mathrm{NaAlSiO}_{4}, \mathrm{Ne}\right)$; kalsilite $\left(\mathrm{KAlSiO}_{4}, \mathrm{Ks}\right)$; quartz $\left(\mathrm{SiO}_{2}, \mathrm{Q}\right)$; and anorthite $\left(\mathrm{CaAl}_{2} \mathrm{Si}_{2} \mathrm{O}_{8}, \mathrm{An}\right)$, and reported these as $\mathrm{Ne}-\mathrm{Ks}-\mathrm{Q}$ and $\mathrm{Ne}-\mathrm{Ks}-\mathrm{An}-\mathrm{Q}$ compositions; although these were given as weight percentages (wt.\%) they were not identified as such. These nepheline compositions were plotted together with those for analysed coexisting alkali feldspars and bulk rock compositions (potential magmatic liquids?), as wt.\% values, in 'petrogeny's residua system' (i.e. with the end-member components $\mathrm{Ne}-\mathrm{Ks}-\mathrm{Qz}$; Schairer and Bowen, 1935). For many years it was reported that natural nephelines have a rather restricted compositional range falling within the Morozewicz-Buerger region (e.g. Tilley, 1954). The International Mineralogical Association (IMA) commission on new minerals, nomenclature and classification (CNMNC) (Hălenius et al., 2018) have recently redefined the formula $\mathrm{Na}_{3} \mathrm{KAl}_{4} \mathrm{Si}_{4} \mathrm{O}_{16}$ as that for 'ideal' nepheline, rather than the previously recommended $\mathrm{NaAlSiO}_{4}$, however in this paper it will be shown that high quality analyses show a wider range of compositions than that implied by this formula.

With the advent of the electron microprobe, analyses of coexisting minerals became more common and many authors continued to report feldspar and feldspathoid (mainly nepheline) mineral compositions as wt.\% proportions of end-members and 
plotted the data in Ne-Ks-Qz and other experimentally determined systems (e.g. Wilkinson, 1965; Henderson and Gibb, 1972; Rock, 1978; Mitchell and Platt, 1979a; Mitchell and Platt, 1982; Wilkinson and Stolz, 1983; Henderson et al., 1989; Brotzu et al., 1997; Melluso, 2012; Zhu et al., 2016). Note that Ne-Ks-Q proportions for nepheline were originally given as wt.\% values by Deer et al. $(1963,1966,1992)$ and were referred to as 'normative percentage'; in effect, their mineral wt.\% proportions are the same as CIPW values where normative albite $(\mathrm{Ab}$, $\mathrm{NaAlSi}_{3} \mathrm{O}_{8}$ ), orthoclase (Or, $\mathrm{KAlSi}_{3} \mathrm{O}_{8}$ ) and leucite (Lc, $\mathrm{KAlSi}_{2} \mathrm{O}_{6}$ ) are recast into the equivalent $\mathrm{Ne}$ and Ks values with the amounts of released $\mathrm{SiO}_{2}$ summed to provide the excess $\mathrm{Q}$ component of the nepheline.

Other authors chose to report nepheline end-member proportions on a molecular per cent basis (e.g. Dollase and Thomas, 1978; Mitchell and Platt, 1979a; Henderson and Gibb, 1983; Henderson and Gibb, 1987; Flohr and Ross, 1990; Wilkinson and Hensel, 1994; Wittke and Holm, 1996; Conceição et al., 2009; Blancher et al., 2010; Henderson et al., 2012; Chakrabarty et al., 2016). However, some authors (e.g. Dollase and Thomas, 1978; Henderson and Gibb, 1987; Wilkinson and Hensel, 1994; Mann et al., 2006; Moller and William-Jones, 2016) obtain much higher end-member molecule estimates for the per cent excess Q component and much lower estimates for the An molecule for similar bulk composition samples than other authors (e.g. Mitchell and Platt, 1982; Flohr and Ross, 1990). Although the calculation methods are not declared in these papers, all calculations provide mole \% data and it is shown here that not all the procedures followed ideal nepheline stoichiometry.

Several different approaches have been made in the past to define the ideal stoichiometry of nepheline in relation to its crystal structure. Thus, although it had been known for some time that natural nepheline was more siliceous $(\mathrm{Si} / \mathrm{Al}>1)$ than the theoretical end-member (Morozewicz, 1930). Bannister and Hey (1931) speculated that the nepheline framework might have a structure derived from that of high-temperature tridymite with $\mathrm{Al}$ replacing $\mathrm{Si}$ and alkalis occupying the 'gaps'. This was subsequently confirmed by Buerger (1954) who classified nepheline (and kalsilite) as being 'stuffed tridymite' derivatives and carnegieite (hightemperature $\mathrm{NaAlSiO}_{4}$ ) as being a 'stuffed cristobalite' derivative; both of these pure-silica phases have polymerised network structures of linked six-rings of $\mathrm{SiO}_{4}$ tetrahedra. Donnay et al. (1959) revisited the atomic formula for natural nephelines and adopted the idealised formula:

$$
\mathrm{K}_{x} \mathrm{Na}_{y} \mathrm{Ca}_{z} \square_{8-(\mathrm{x}+\mathrm{y}+\mathrm{z})}\left[\mathrm{Al}_{(\mathrm{x}+\mathrm{y}+2 \mathrm{z})} \mathrm{Si}_{16-(\mathrm{x}+\mathrm{y}+2 \mathrm{z})} \mathrm{O}_{32}\right]
$$

where $\square$ defines the vacant cavity cation sites; square brackets to enclose the tetrahedral aluminosilicate framework have been added here.

Barth (1963) suggested that the nepheline structure could be considered as containing four mineral molecules plus 'holes' (vacant interframework cavity sites) all of which were defined using the same number of oxygens in their tetrahedral frameworks; the total of framework plus cavity cation sites plus holes is 24 sites per 32 oxygens as follows:

$$
24 \mathrm{Ne} \text { (nepheline, } \mathrm{NaAlSiO}_{4} \text { ) } \rightarrow \mathrm{Na}_{2} \mathrm{Na}_{6} \mathrm{Al}_{8} \mathrm{Si}_{8} \mathrm{O}_{32}
$$

$24 \mathrm{Ks}$ (kalsilite, $\left.\mathrm{KAlSiO}_{4}\right) \rightarrow \mathrm{K}_{2} \mathrm{~K}_{6} \mathrm{Al}_{8} \mathrm{Si}_{8} \mathrm{O}_{32}$

$$
\begin{gathered}
24 \mathrm{An}^{\prime}\left(20 \text { An anorthite, } \mathrm{CaAl}_{2} \mathrm{Si}_{2} \mathrm{O}_{8}+4 \square\right) \\
\rightarrow \square_{2} \square_{2} \mathrm{Ca}_{4} \mathrm{Al}_{8} \mathrm{Si}_{8} \mathrm{O}_{32} \\
24 \mathrm{Q}^{\prime}\left(16 \mathrm{Q} \text { tridymite, } \mathrm{SiO}_{2}+8 \square\right) \rightarrow \square_{8} \mathrm{Si}_{8} \mathrm{Si}_{8} \mathrm{O}_{32}
\end{gathered}
$$

Two cavity cation sites were used to represent the presence of two distinct interframework cations in natural nepheline (e.g. Hahn and Buerger, 1955; Dollase, 1970). Barth pointed out that the 'holes' are potential sites for cavity cations and that these "will be reckoned as cations and included in the equivalent molecular percentages" however he didn't always follow that 'rule'. In addition, Barth (1963; his fig. 2) used the quaternary system Ne-Ks-Q'-An' to define a triangular "compositional plane for natural nephelines" with corners defined by the components $\mathrm{Na}_{6} \mathrm{~K}_{2} \mathrm{Al}_{8} \mathrm{Si}_{8} \mathrm{O}_{32}, \quad \mathrm{Na}_{6} \square_{2} \mathrm{Al}_{6} \mathrm{Si}_{10} \mathrm{O}_{32}$ and $\mathrm{Na}_{4} \mathrm{Ca}_{2} \square_{2} \mathrm{Al}_{8} \mathrm{Si}_{8} \mathrm{O}_{32}$; that figure correctly shows the second and third components at $\mathrm{Ne}_{75} \mathrm{Q}_{25}$ and $\mathrm{Ne}_{50} \mathrm{An}_{50}$, respectively, consistent with their vacancy contents.

Rossi et al. (1989) gave another version of the nepheline ideal formula as:

$$
\mathrm{K}_{p} \mathrm{Na}_{(8-p-2 q-r)} \mathrm{Ca}_{q} \square_{(q+r)}\left[\mathrm{Al}_{(8-r)} \mathrm{Si}_{(8+r)}\right] \mathrm{O}_{32}
$$

where exchange of $\mathrm{K}$ for $\mathrm{Na}$ is denoted $p, \mathrm{Ca}+\square$ for $2 \mathrm{Na}$ is $q$, and $r$ denotes the excess of $\mathrm{Si}$ exchanged for Al. The work of Donnay et al. (1959) and Barth (1963) showed that the entry of Ca into the cavity sites is matched by entry of a linked vacancy and that the excess of $\mathrm{Si}\left(\mathrm{Si}^{\mathrm{xs}}\right)$ in the framework is accompanied by half of that value 'entering' the cavity site. The Rossi et al. (1989) formula shows these requirements clearly. In their authoritative text on feldspathoids (Deer et al., 2004) they changed from the wt.\% basis used in their early books to a mol.\% basis. Although they give the end-member $\mathrm{Ne}-\mathrm{Ks}-\mathrm{An}-\mathrm{Q}$ compositions on a molecular basis, they do not explain the procedure used; however, it is possible that they followed the Barth (1963) method. The most recent student text (Deer et al., 2013) also gave end-member data as mol.\% values though some of the end-member calculations are unreliable (this work).

It is not straightforward to decide on how best to calculate endmember components as mol.\% values to follow ideal nepheline stoichiometry. In this paper first principles are used to convert ideal nepheline atomic formula for the $\mathrm{Ne}-\mathrm{Q}$ series, the $\mathrm{Ne}-\mathrm{An}$ series, and ternary compositions in the system Ne-Q-An to obtain wt.\% bulk compositions of oxides. These wt.\% oxide values are used to develop the protocols to calculate unit cell (32 oxygen) atomic formulae and hence molecular data of the correct form; some potential difficulties will emerge here regarding other proposed procedures. These methods will be used to assess representative published compositional data in a newly assembled database of $\sim 310$ published microprobe nepheline analyses, and to decide on the most appropriate methods to recommend for dealing with chemical and microprobe analyses of this mineral type.

\section{Nepheline stoichiometry and structure; a review of earlier approaches}

Key background compositional information is summarised here with more detail provided in the Supplementary materials, section S.2 (see below). 
In an early paper, Bannister and Hey (1931) deduced that the unit cell atomic formulae should be calculated to 32 oxygen atoms. They found that $\mathrm{Si}+\mathrm{Al}$ averaged 15.995 (range 15.8316.13), consistent with 16 framework cations per unit cell and with the number of $\mathrm{Al}$ atoms matching the sum of cavity site elements $(2 \mathrm{Ca}+\mathrm{Na}+\mathrm{K})$. Their $\mathrm{Si} / \mathrm{Al}$ averaged 1.10 showing that natural nepheline is consistently more siliceous than the $(\mathrm{Na}, \mathrm{K})$ $\mathrm{AlSiO}_{4}$ composition with $\sim 10$ atom\% of excess silica. Bowen (1912a) reported a mean formula of $(\mathrm{Na}, \mathrm{K})_{8} \mathrm{Al}_{8} \mathrm{Si}_{9} \mathrm{O}_{34}$ and he was the first to attribute this to the solid solution of albite $\left(\mathrm{NaAlSi}_{3} \mathrm{O}_{8}\right)$ in nepheline. Greig and Barth (1938) subsequently determined that the limit of solid solution of albite at 1 bar pressure dry is $\sim 33$ wt.\% $\left(\mathrm{Ne}_{67} \mathrm{Ab}_{33}\right.$, wt.\%), which is equivalent to $\mathrm{Ne}_{85} \mathrm{Qz}_{15}$ (wt.) and $\mathrm{Ne}_{83} \mathrm{Qz}_{17}$ (mol.\%). The literature survey of nepheline compositions in Bannister and Hey (1931) commonly shows the presence of a significant $\mathrm{Ca}$ component whereas their new nepheline analyses showed a range of $\mathrm{CaO}$ from 1.99 to 2.51 wt.\% ( 10-12.5 wt.\% An). Bowen (1912b) had already demonstrated experimentally at 1 bar that the maximum amount of solid solution of An in nepheline is $35 \mathrm{wt} . \%$ (7.5 wt.\% $\mathrm{CaO}$ ). See the Supplementary files for more information on Ca contents.

Smith and Sahama (1954) used synthetic Ne-Ks solid solutions together with analyses of natural nephelines to develop a powder X-ray diffraction method (202 and 210 peaks) for obtaining compositions for unanalysed samples. For the natural nephelines their table III gives calculated $[(\mathrm{Na}+\mathrm{Ca}) \times 100] / T$ and $\mathrm{K} \times$ $100 / T$ atomic ratios where $T=1 / 2(\mathrm{Si}+\mathrm{Al}+\mathrm{Fe}+\mathrm{Mn}+\mathrm{Mg}+\mathrm{Ti})$. In effect they assumed that $\mathrm{Fe}, \mathrm{Mn}, \mathrm{Mg}$ and $\mathrm{Ti}$ joined $\mathrm{Si}$ and $\mathrm{Al}$ in the tetrahedral framework and it is clear that one half of the sum of the $\mathrm{T}$ sites (ideally 16 for 32 oxygen, strict nepheline stoichiometry) provides estimates of the number of cations in the cavity sites (ideally 8). Thus, these values provide values for the occupancy of the cavity sites and the deficit from 100 provides an estimate of the vacancies in those sites. Also they show (their table III) percentages for the excess Si present in solid solution for the natural nephelines. Thus, based on numbers of atoms: \% excess $\mathrm{Si}=($ total $\mathrm{Si}-T) \times 100 / T$. This calculation provides the $\%$ of total excess Si relative to the occupancy of the cavity site, however, nepheline stoichiometry shows that the vacancy associated with the excess Si molecule is actually half of the total calculated excess Si. Thus, the breakdown of the cavity site occupants is not shown correctly for the Smith and Sahama calculation. For example, the Dunedin phonolite sample 63197 (Tilley, 1954) would have a cavity site occupancy for Q' (vacancies associated with excess $\mathrm{Si}$ ) of $8.3 \%$ rather than 16.9 as shown by Smith and Sahama (1954) in their table III. This new value shows much better agreement with their reported vacant alkali site value of $6.2 \%$. Smith and Sahama (1954) also report that the determinative graphs show changes of slope at a ratio of 0.25 for $\mathrm{K} /(\mathrm{K}+\mathrm{Na}$ $+\mathrm{Ca}$ ) (atomic), and Smith and Tuttle (1957) later confirmed such discontinuities using cell parameter data.

Donnay et al. (1959) subsequently used powder X-ray diffraction (XRD) methods to assess changes in hexagonal unit-cell parameters in four series of synthetic nepheline-structured solid solution series: $\mathrm{Ne}-\mathrm{Ks}, \mathrm{Ne}-\mathrm{Ab}, \mathrm{Ne}-\mathrm{An}$, and $\mathrm{Ne}-\mathrm{CaAl}_{2} \mathrm{O}_{4}$; note that solid solutions in the $\mathrm{Ne}-\mathrm{Ab}$ series and in the $\mathrm{Ne}-\mathrm{An}$ series will both have cavity cation site vacancies. It is clear that any $\mathrm{Fe}^{3+}$ present would substitute for $\mathrm{Si}$ and $\mathrm{Al}$ in tetrahedral coordination to form an iron nepheline component and Donnay et al. (1959) suggested that the small amounts of $\mathrm{Mg}, \mathrm{Mn}$ and $\mathrm{Ti}$ that might be present within the nepheline structure could substitute for $\mathrm{Na}, \mathrm{K}$, or $\mathrm{Ca}$, rather than being in impurity mineral phases (see
Dollase and Thomas, 1978). Shortly after the Donnay paper, Hamilton (1961) and Hamilton and MacKenzie (1960) reported on the results for the experimental determination of nepheline compositions in petrogeny's residua system at 1 kbar $\mathrm{P}_{\mathrm{H}_{2} \mathrm{O}}$ as a function of temperature and defined limits of solid solution of albite in nepheline. They report one ternary composition as having the formulae $\mathrm{Ne}_{73.5} \mathrm{Ks}_{22.5} \mathrm{Qz}_{4.0}$ (wt.\%), $\mathrm{Ne}_{71.24} \mathrm{Ks}_{19.59} \mathrm{Qz}_{9.37}$ (mol.\%) and $\mathrm{Na}_{5.97} \mathrm{Ks}_{1.64} \square_{0.39} \mathrm{Al}_{7.51} \mathrm{Si}_{8.39} \mathrm{O}_{32}$ (Hamilton and MacKenzie, 1960). Note the much higher molecular per cent content of Qz compared to the equivalent wt.\% value; it is clear that a molecular weight of 60 for $\mathrm{Si}$ was used to convert weight to molecular amounts for the excess Q component (denoted here as $\left.\mathrm{Q}^{\mathrm{xs}}\right)$. That protocol is also used by Dollase and Thomas (1978). Based on $\mathrm{Q}^{\mathrm{xs}}$ having the same number of oxygens as $\mathrm{Ne}$ (i.e. $\mathrm{Si}_{2} \mathrm{O}_{4}$ ) and a molecular weight of 120 , this Hamilton and MacKenzie composition would be $\mathrm{Ne}_{75.7} \mathrm{Ks}_{20.5} \mathrm{Qz}_{4.8}$ (molecular per cent).

Hamilton and MacKenzie (1960) drew the join from $\mathrm{Na}_{6} \mathrm{~K}_{2} \mathrm{Al}_{8} \mathrm{Si}_{8} \mathrm{O}_{32}$ to a point at $40 \%$ of the $\mathrm{Q}$ component that is incorrectly labelled $\mathrm{Na}_{6} \square_{2}$ (i.e. $\mathrm{Na}_{6} \square_{2} \mathrm{Al}_{6} \mathrm{Si}_{10} \mathrm{O}_{32}$ ) on the $\mathrm{Na}_{8} \mathrm{Al}_{8} \mathrm{Si}_{8} \mathrm{O}_{32}(8 \mathrm{Ne})-8 \mathrm{SiO}_{2}$ join on a mol.\% version of the $\mathrm{Ne}-\mathrm{Ks}-\mathrm{Q}$ system. Note that the number of oxygens of the $\mathrm{Q}$ corner is half of that defined for a 32 oxygen unit cell. Dollase and Thomas (1978) also discuss the join $\mathrm{Na}_{6} \mathrm{~K}_{2} \mathrm{Al}_{8} \mathrm{Si}_{8} \mathrm{O}_{32}-$ $\mathrm{Na}_{6} \square_{2} \mathrm{Al}_{6} \mathrm{Si}_{10} \mathrm{O}_{32}$, which is one of the side-lines of Barth's "compositional plane for natural nephelines", and show it on the system $\mathrm{NaAlSiO}_{4}-\mathrm{KAlSiO}_{4}-\mathrm{SiO}_{2}(\mathrm{~mol} . \%)$ without labelling the end points of the join. The terminations of the join are shown at $25 \% \mathrm{Ks}$ and $40 \%$ of Q. Henderson and Gibb (1983) and Wilkinson and Hensel (1994) followed Dollase and Thomas in plotting the 'join' in a $\mathrm{NaAlSiO}_{4}-\mathrm{KAlSiO}_{4}-\mathrm{SiO}_{2}$ (mol.\%) triangle, but incorrectly label the ends of this join. The rigorous way of displaying ideal nepheline stoichiometry is to define each of the end-members on a 32 oxygen basis, i.e. $\mathrm{Na}_{8} \mathrm{Al}_{8} \mathrm{Si}_{8} \mathrm{O}_{32}$ $\mathrm{K}_{8} \mathrm{Al}_{8} \mathrm{Si}_{8} \mathrm{O}_{32}-\square_{8} \mathrm{Si}_{16} \mathrm{O}_{32}$; the composition $\mathrm{Na}_{6} \square_{2} \mathrm{Al}_{6} \mathrm{Si}_{10} \mathrm{O}_{32}$ would then plot at $75 \%$ and $25 \%$ of the $\mathrm{Na}$ - and $\mathrm{Si}$ - end-members of the join rather than the $60 \%$ and $40 \%$ proportions implied by Henderson and Gibb (1983). These differences result from the Q component having half the number of oxygens required for ideal nepheline stoichiometry; note that Blancher et al. (2010) show the correct geometry in their figure 8 (see Supplementary material, section S.2 for related information).

Natural nephelines crystallise with hexagonal symmetry $\left(\mathrm{PG}_{3}\right.$ space group) and have stuffed-tridymite structures with the $\mathrm{Na}$, $\mathrm{K}, \mathrm{Ca}$ and associated vacancies occupying the cavity cation sites that are defined by the holes in the six-ring, polyhedral framework. All natural nephelines have two distinct cation sites with $\mathrm{Na}$ tending to occupy the smaller, and $\mathrm{K}$ and vacancies $(\square)$ the larger sites (e.g. Hahn and Buerger, 1955; Dollase, 1970); the $\mathrm{Ca}$ position is not clear (Hahn and Buerger, 1955). The presence of iron as $\mathrm{Fe}^{3+}$ substituting for $\mathrm{Al}$ in the tetrahedral sites is well established in framework silicates and it is usually reported as such in microprobe analyses of nepheline. Wet-chemical analyses of nepheline separates sometimes contain very small amounts of $\mathrm{Mg}, \mathrm{Fe}^{2+}, \mathrm{Mn}$ and $\mathrm{Ti}$, although these components probably result from the presence of grain impurities and/or alteration products (Dollase and Thomas, 1978). However, synthetic leucite analogues are known to contain large amounts of divalent cations (e.g. Mg, $\mathrm{Zn}, \mathrm{Co}, \mathrm{Fe}^{2+}, \mathrm{Cd}$ ) in the polymerised framework of general formulae $\mathrm{K}_{2} \mathrm{M}^{2+} \mathrm{Si}_{5}^{4+} \mathrm{O}_{12}$ (e.g. Roedder,1951; Torres-Martinez and West, 1989; Henderson et al., 1998, 2017) involving the coupled substitution $2 \mathrm{Al}^{3+} \rightarrow \mathrm{M}^{2+}+\mathrm{Si}^{4+}$. Roedder reported the synthesis of 
hexagonal nepheline-like phases of composition $\mathrm{K}_{2}\left[\mathrm{MgSi}_{3} \mathrm{O}_{8}\right]$ (Roedder, 1951) and $\mathrm{K}_{2}\left[\mathrm{Fe}^{2+} \mathrm{Si}_{3} \mathrm{O}_{8}\right]$ (Roedder, 1952, 1978; also see Buerger, 1954). Other 'exotic' synthetic silicate phases also have stuffed-tridymite frameworks that contain divalent cations and $\mathrm{Si}$ in separate tetrahedral sites, e.g. $\mathrm{BaMSiO}_{4}$ with $M=\mathrm{Co}$, $\mathrm{Zn}, \mathrm{Mg}$ (Liu and Barbier, 1993). Inclusions and composite grains can be avoided using the electron microprobe (Dollase and Thomas, 1978) and, if found using high-quality microprobe analysis, it is possible that small contents of $\mathrm{Mg}, \mathrm{Mn}$ and $\mathrm{Ti}$ might occupy the nepheline framework, and that all $\mathrm{Ca}$ replaces $\mathrm{Na}$ in the cavity sites. In addition, Dollase (1998) showed that $\mathrm{Mg}$, $\mathrm{Zn}$, Co and Cd occurred in tetrahedral coordination in stuffed cristobalites, whereas complete solid solutions in the system $\mathrm{SrAl}_{2} \mathrm{O}_{4}-\mathrm{BaAl}_{2} \mathrm{O}_{4}$ show that $\mathrm{Sr}$ and $\mathrm{Ba}$ occupy cavity sites in kalsilite-like structures that have stuffed tridymite topology (Henderson and Taylor, 1982). Thus, in the following sections of this paper it will be assumed that smaller divalent cations ( $\mathrm{Mg}, \mathrm{Mn}$ etc) and Ti will replace $\mathrm{Si}$ in the tetrahedral framework whereas larger cations $\mathrm{Ca}, \mathrm{Sr}$ and $\mathrm{Ba}$ and Rb (Roux, 1974) will replace $\mathrm{K}$ and $\mathrm{Na}$ in the cavity sites. The calcic molecule will be referred to as $\mathrm{CaNe}$ (calcium-Ne, formula $\square_{0.5}^{\mathrm{Ca}} \mathrm{Ca}_{0.5} \mathrm{AlSiO}_{4}$ ) rather than An' (Barth, 1963) and total excess silica as $\mathrm{Q}^{\mathrm{xs}}\left[\mathrm{Si}^{\mathrm{xs}}+\square^{\mathrm{Si}}\right.$, where $\mathrm{Si}^{\mathrm{xs}}$ is the excess $\mathrm{Si}$ within the framework and $\square^{\text {Si }}$ $\left(=\mathrm{Si}^{\mathrm{xs}} / 2\right)$ is the cavity site vacancy associated with the excess $\left.\mathrm{Si}\right]$.

\section{Calculation of nepheline end-member molecules.}

For calculating molecular proportions from analyses of nephelines it appears that two approaches have been used. The values reported by Dollase and Thomas (1978), Henderson and Gibb (1983) and Wilkinson and Hensel (1994) used the atomic formulae of end-members as $\mathrm{NAlSiO}_{4}(\mathrm{Ne}), \mathrm{KAlSiO}_{4}(\mathrm{Ks}), \mathrm{CaAl}_{2} \mathrm{Si}_{2} \mathrm{O}_{8}$ $(\mathrm{An})$ and $\mathrm{SiO}_{2}(\mathrm{Qz})$ in which different components are defined using different numbers of oxygens. If ideal nepheline stoichiometry is to be followed then all end-members should be defined in the same manner and conform to a 32 oxygen unit cell: in that case the simple formula units $(Z=8)$ should be based on $\mathrm{NaAlSiO}_{4}, \mathrm{KAlSiO}_{4}, \mathrm{Ca}_{0.5} \mathrm{AlSiO}_{4}$ and $\mathrm{Si}_{2} \mathrm{O}_{4}$, respectively. In this paper the 'symbols' $\mathrm{Ne}$ and $\mathrm{Ks}$ (as before), $\mathrm{CaNe}$ (calcium nepheline) and $\mathrm{Q}^{\mathrm{xs}}$ ('excess' silica $=\square^{\mathrm{Si}}+\mathrm{Si}^{\mathrm{xs}}$ ) will be used. On that basis the molecular weights of the four components are $\mathrm{Ne}$ 142.05, Ks 158.16, CaNe 139.10 and $\mathrm{Q}^{\mathrm{xs}}\left(=\square^{\mathrm{Si}} \mathrm{Si}_{2} \mathrm{O}_{4}\right)$ 120.16. The molar amount of $\mathrm{CaNe}$ is defined as containing only half a calcium atom (i.e. $\mathrm{Ca}_{0.5} \mathrm{AlSiO}_{4}$ ), thus on an ideal nepheline stoichiometry basis the proportion of $\mathrm{CaNe}$ is calculated as $2 \times$ the $\mathrm{Ca}$ atom number (which has the same value as the sum of $\mathrm{Ca}$ atoms plus the same number of associated vacancies; i.e. 4 of each per unit cell). The proportion of $\square^{\mathrm{Si}}$ is half of the total excess $\mathrm{Si}^{\mathrm{xs}}$ in the framework, which matches the number of $\mathrm{Si}_{2} \mathrm{O}_{4}$ molecules per unit cell (i.e. 8).

The first step is to develop the approach for the solid solution series for $\mathrm{Ne}-\mathrm{Q}, \mathrm{Ne}-\mathrm{Ca}_{0.5} \mathrm{AlSiO}_{4}$, and $\mathrm{Ne}-\mathrm{Ca}_{0.5} \mathrm{AlSiO}_{4}-\mathrm{Q}$ separately, on the basis of a 32 oxygen, stuffed-tridymite tetrahedral framework, starting with numbers of constituent cation numbers and including the vacancies required to match the proportions of $\mathrm{Ca}$ and excess $\mathrm{Si}$. Examples for each of the three systems are shown in Table 1. In each case hypothetical compositions are used to clarify the principles of the site occupancy calculations; thus some of the compositions shown will be outside the natural nepheline composition ranges expected. Selected compositions for each of the systems will be discussed to establish the most significant aspects of the compositional and structural features. In all cases, the starting point is to display the site occupancies of atom species on the basis of 32 oxygen cells. The same equations are used to define end-member proportions for each of the systems and the different equations will be explained for the first system (i.e. $\mathrm{Ne}-\mathrm{Q})$. Note that for these three model systems Barth's An' and Q' terms are used initially (rather than $\mathrm{CaNe}$ and $\mathrm{Q}^{\mathrm{xs}}$ as defined here) to be consistent with earlier notation.

\section{Ne-Q solid-solution series}

Compositions are chosen with some at $10 \% \mathrm{Q}$ intervals with others having integral numbers of cavity site vacancies. The unit cell with 32 oxygen cations has 24 sites of which 16 are tetrahedral cations in framework sites and 8 are cavity cations and vacancies occupying the interframework (cavity) sites.

Five representative examples for this solid-solution series will be discussed here. Thus the top five rows of data in Table 1 show atomic occupancies for the two end-members $100 \mathrm{Ne}$ $\left(\mathrm{Na}_{8} \mathrm{Al}_{8} \mathrm{Si}_{8} \mathrm{O}_{32}\right)$ and 100Q $\left(\square_{8} \mathrm{Si}_{16} \mathrm{O}_{32}\right)$, and for three intermediate compositions: 87.5Ne12.5Q $\left(\square_{1} \mathrm{Na}_{7} \mathrm{Al}_{7} \mathrm{Si}_{9} \mathrm{O}_{32}\right)$; 70Ne30Q $\left(\square_{2.4}\right.$ $\left.\mathrm{Na}_{5.6} \mathrm{Al}_{5.6} \mathrm{Si}_{10.4} \mathrm{O}_{32}\right)$; 50Ne50Q $\left(\square_{4} \mathrm{Na}_{4} \mathrm{Al}_{4} \mathrm{Si}_{12} \mathrm{O}_{32}\right)$. The first column shows the number of vacancies in the cavity sites for each sample; in this system all of the vacancies result from the presence of the excess Si component of the solid solution. The next column is not relevant for this system. The third column shows the number of $\mathrm{Na}$ atoms present in the cavity sites for each sample. The fourth column is not relevant for this system. Column 5 shows the atoms of tetrahedral $\mathrm{Al}$ for the $\mathrm{Ne}$ component and column 6 shows the tetrahedral Si contents for Ne. Column 7 gives the tetrahedral $\mathrm{Si}$ contents $\left(\mathrm{Si}^{\mathrm{xs}}\right)$ for the excess $\mathrm{Q}^{\mathrm{xs}}$ component where the excess silica molecule is defined as $\mathrm{Si}_{2} \mathrm{O}_{4}$ (see Blancher et al., 2010; Hamada et al., 2019) to keep the same number of oxygens as for the other end-members. Thus, the number of silicons associated with the excess $\mathrm{Q}^{\mathrm{xs}}$ molecule is double the number given in column 7 and that molecule has a molecular weight of 120.16 rather than 60.08 . Note that the tetrahedral $\mathrm{Al}+\mathrm{Si}$ always total 16 and that the cavity sites total 8 , which includes both $\mathrm{Na}$ cations and vacancies associated with the presence of the excess Q'; the total of cations plus vacancies is always 24. Two important features are defined here: the number of vacancies in the cavity site $\left(\square^{\mathrm{Si}}\right)$ is exactly half of the excess $\mathrm{Si}^{\mathrm{xs}}$ value and matches the amount of the $\mathrm{Si}_{2} \mathrm{O}_{4}$ molecule; no vacancies are associated with the $\mathrm{Na}$ component. These features are fixed by the unique nepheline stoichiometry and structure. Column 9 shows the \% of $\mathrm{Ne}$ component; this is calculated following Barth (1963):

$$
\% \mathrm{Ne}=(3 \times \text { atoms of } \mathrm{Na}) \times 100 / 24
$$

where stoichiometric $\mathrm{Ne}$ has equal numbers of $\mathrm{Na}, \mathrm{Al}$ and $\mathrm{Si}$ atoms so the total cations in $\mathrm{Ne}$ can be calculated as $3 \times$ the $\mathrm{Na}$ value. As expected the top five bulk compositions are simply $100 \% \mathrm{Ne}, 87.5 \%, 70 \%, 50 \% \mathrm{Ne}$ and $0 \% \mathrm{Ne}$; the same result would be obtained by simply taking the number of $\mathrm{Na}$ atoms in each sample and relating that to the total number of cavity sites in the structure, i.e. 8 .

In columns 10 to 14 the calculations for obtaining values for Barth's An' and Q' (cf. CaNe and $\mathrm{Q}^{\mathrm{xs}}$ ) components are shown; columns 10 and 11 are not relevant to the Ca-free compositions nevertheless several problems would emerge for Ca-bearing samples. Thus, column 10 shows Barth's (1963) equation for calculating the $\mathrm{Ca}$ end-member for natural nephelines and it is necessary to explain the protocol here. The atomic proportions for An were 
Table 1. Occupancies of cavity and framework sites in model stoichiometric nephelines, mol.\% end-members and wt.\% oxide compositions.

\begin{tabular}{|c|c|c|c|c|c|c|c|c|c|c|c|c|c|c|c|c|c|}
\hline & 1 & 2 & 3 & 4 & 5 & 6 & 7 & 8 & 9 & 10 & 11 & 12 & 13 & 14 & 15 & 16 & 17 \\
\hline \multirow[t]{2}{*}{$\begin{array}{l}\text { Bulk compos. } \\
\text { (molecular) }\end{array}$} & $\begin{array}{l}\text { Cation } \\
\text { vacancy }\end{array}$ & $\begin{array}{l}\text { Cation } \\
\text { vacancy }\end{array}$ & $\mathrm{Na}$ & $\mathrm{Ca}$ & Al & $\mathrm{Si}$ & $\begin{array}{l}\text { Excess } \mathrm{Si} \text { in } \\
\text { framewk. }\end{array}$ & 0 & $\begin{array}{l}\text { Correct Ne } \\
\text { Barth } 63\end{array}$ & An' Barth 63 & $\begin{array}{c}\text { Correct } \\
\text { An' }=\mathrm{CaNe}\end{array}$ & $\begin{array}{c}\text { Excess Si Q'? } \\
\text { Barth } 1963\end{array}$ & Correct Q' & $\begin{array}{l}\mathrm{Na}_{2} \mathrm{O} \\
\text { wt. } \%\end{array}$ & $\begin{array}{l}\mathrm{CaO} \\
\mathrm{wt} . \%\end{array}$ & $\begin{array}{l}\mathrm{Al}_{2} \mathrm{O}_{3} \\
\text { wt.\% }\end{array}$ & $\begin{array}{l}\mathrm{SiO}_{2} \\
\text { wt. } \%\end{array}$ \\
\hline & $\begin{array}{l}\text { From Si } \\
\square^{\mathrm{Si}}=\mathrm{Si}^{\mathrm{xs}} / 2\end{array}$ & $\begin{array}{l}\text { From Ca } \\
\square^{\mathrm{Ca}}=\mathrm{Ca}\end{array}$ & $\begin{array}{l}\mathrm{Ne} \\
8 \times \mathrm{NaAlSiO}_{4}\end{array}$ & $\begin{array}{l}\mathrm{An} \\
8 \times \mathrm{Ca}_{0.5} \mathrm{AlSiO}_{4}\end{array}$ & $\mathrm{Ne}, \mathrm{An}$ & $\mathrm{Ne}, \mathrm{An}$ & $\begin{array}{l}\mathrm{Si}^{\mathrm{xs}} \\
8 \times \mathrm{Si}_{2} \mathrm{O}_{4}\end{array}$ & & & & $\mathrm{Ca}_{0.5} \mathrm{AlSiO}_{4}$ & & $\begin{array}{l}\mathrm{Q}^{\mathrm{xs}}=\mathrm{Si}^{\mathrm{xs}}+\square^{\mathrm{Si}} \text { or } \\
\mathrm{Q}^{\mathrm{xs}}=1.5 \times \mathrm{Si}^{\mathrm{xs}}\end{array}$ & & & & \\
\hline $\begin{array}{l}\text { Molecular wt. } \\
\text { and } \\
\text { formulae }\end{array}$ & & & 142.05 & 139.10 & & & 120.16 & & $\begin{array}{l}(3 \mathrm{Na} \times 100) / 24 \\
\text { Barth }(1963) \\
\text { or }(\mathrm{Na} \times 100) / 8\end{array}$ & $\begin{array}{l}(5 \mathrm{Ca} \times 100) / \\
24 \text { Barth } \\
(1963)\end{array}$ & $\begin{array}{c}(6 \times C a \times 100) / 24 \\
\text { or } 2 C a \times 100 / 8\end{array}$ & $\begin{array}{l}\mathrm{Q}^{\mathrm{xs}} \text { Total excess \% } \\
(24-3 \mathrm{Na}- \\
5 \mathrm{Ca}) \times 100 / 24\end{array}$ & $\begin{array}{l}(24-3 \mathrm{Na}-6 \mathrm{Ca} a) \times 100 / 24 \\
\text { or }(\mathrm{Si}-\mathrm{Na}-2 \mathrm{Ca}) \times \\
100 / 16 \text { or }(8-\mathrm{Na}- \\
2 \mathrm{Ca}) \times 100 / 8 \mathrm{Also} \\
(\mathrm{Si}-\mathrm{Al}) \times 100 / 16\end{array}$ & & & & \\
\hline $100 \mathrm{Ne}$ & 0 & 0 & 8 & 0 & 8,0 & 8 & 0 & 32 & 100 & 0 & 0 & 0 & 0 & 21.82 & 0 & 35.89 & 42.30 \\
\hline 87.5Ne12.5Q & 1 & 0 & 7 & 0 & 7 & 7 & $\begin{array}{l}1\left(\mathrm{Si}_{2}\right)^{8} \\
\text { i.e. } 2 \mathrm{Si}\end{array}$ & 32 & 87.5 & 0 & 0 & $\begin{array}{l}\text { Q' } 12.5 \% \\
\mathrm{Si}^{\mathrm{xs}} 8.34 \\
\square^{\mathrm{Si}} 4.17\end{array}$ & 12.5 & 19.45 & 0 & 32.02 & 48.52 \\
\hline 70Ne30Q & 2.4 & 0 & 5.6 & 0 & 5.6 & 5.6 & $\begin{array}{l}\text { 2.4 }\left(\mathrm{Si}_{2}\right)^{8} \\
\text { i.e. } 4.8 \mathrm{Si}\end{array}$ & 32 & 70 & 0 & 0 & $\begin{array}{l}\text { Q' } 30 \% \\
\mathrm{Si}^{\mathrm{xi}} 20 \\
\square^{\mathrm{Si}} 10\end{array}$ & 30 & 16.01 & 0 & 26.34 & 57.65 \\
\hline 50Ne50Q' & 4 & 0 & 4 & 0 & 4,0 & 4 & $\begin{array}{l}4\left(\mathrm{Si}_{2}\right)^{\&} \\
\text { i.e. } 8 \mathrm{Si}\end{array}$ & 32 & 50 & 0 & 0 & $\begin{array}{c}\text { Q' } 50 \% \\
\mathrm{Si}^{\mathrm{xs}} 33.33 \\
\square^{\mathrm{Si}} 16.66\end{array}$ & 50 & 11.82 & 0 & 19.44 & 68.74 \\
\hline 100Q' & 8 & 0 & 0 & 0 & 0,0 & 0 & $\begin{array}{l}8\left(\mathrm{Si}_{2}\right)^{\&} \\
\text { i.e. } 16 \mathrm{Si}\end{array}$ & 32 & 0 & 0 & 0 & $\begin{array}{c}Q^{\prime} 100 \% \\
\mathrm{Si}^{\mathrm{xs}} 66.66 \\
\square^{\mathrm{Si}} 33.33\end{array}$ & 100 & 0 & 0 & 0 & 100.00 \\
\hline $100 \mathrm{Ne}$ & 0 & 0 & 8 & 0 & 8,0 & 8 & 0 & 32 & 100 & 0 & 0 & 0 & 0 & 21.82 & 0 & 35.89 & 42.30 \\
\hline 90Ne10An & 0 & 0.4 & 7.2 & 0.4 & $7.2,0.8$ & 8 & 0 & 32 & 90 & 8.33 & 10 & $1.67 \square^{\mathrm{ca}}$ & 0 & 19.67 & 1.98 & 35.96 & 42.47 \\
\hline $80 \mathrm{Ne} 20 \mathrm{An}$ & 0 & 0.8 & 6.4 & 0.8 & $6.4,1.6$ & 8 & 0 & 32 & 80 & 16.66 & 20 & $3.33 \square^{\mathrm{ca}}$ & 0 & 17.52 & 3.96 & 36.04 & 42.56 \\
\hline 50Ne50An' & 0 & 2 & 4 & 2 & 4,4 & 8 & 0 & 32 & 50 & 41.67 & 50 & $8.33 \square^{\mathrm{ca}}$ & 0 & 11.02 & 9.97 & 36.63 & 42.74 \\
\hline 100An' & 0 & 4 & 0 & 4 & 0,8 & 8 & 0 & 32 & 0 & 83.33 & 100 & $16.7 \square^{\mathrm{ca}}$ & 0 & 0 & 20.16 & 36.65 & 43.19 \\
\hline 40Ne40An'20Q' & 1.6 & 1.6 & 3.2 & 1.6 & $3.2,3.2$ & $3.2,3.2$ & $\begin{array}{l}1.6\left(\mathrm{Si}_{2}\right) \\
\text { i.e. } 3.2 \mathrm{Si}\end{array}$ & 32 & 40 & 33.33 & 40 & $\begin{array}{l}Q^{\prime} ? 26.67 \\
\mathrm{Si}^{\mathrm{is}} 13.33 \\
\square^{\mathrm{Si}} 6.67 \\
\square^{\mathrm{Ca}} 6.67\end{array}$ & 20 & 9.08 & 8.22 & 29.88 & 52.82 \\
\hline 20Ne30An'50Q' & 4 & 1.2 & 1.6 & 1.2 & $1.6,2.4$ & $1.6,2.4$ & $\begin{array}{l}4\left(\mathrm{Si}_{2}\right) \\
\text { i.e. } 8 \mathrm{Si}\end{array}$ & 32 & 20 & 25 & 30 & $\begin{array}{c}Q^{\prime} ? 55.0 \\
\mathrm{Si}^{\mathrm{is}} 33.33 \\
\square^{\mathrm{Si}} 16.67 \\
\square^{\mathrm{Ca}} 5.0\end{array}$ & 50 & 4.76 & 6.46 & 19.57 & 69.21 \\
\hline 50Ne20An30Q' & 2.4 & 0.8 & 4 & 0.8 & $4,1.6$ & $4,1.6$ & $\begin{array}{l}2.4\left(\mathrm{Si}_{2}\right) \\
\text { i.e. } 4.8 \mathrm{Si}\end{array}$ & 32 & 50 & 16.67 & 20 & $\begin{array}{l}\text { Q'? } 33.33 \\
\text { Si' } 20 \\
\square^{\text {Si }} 10 \\
\square^{\mathrm{Ca}} 3.33\end{array}$ & 30 & 11.49 & 4.16 & 26.45 & 57.90 \\
\hline
\end{tabular}

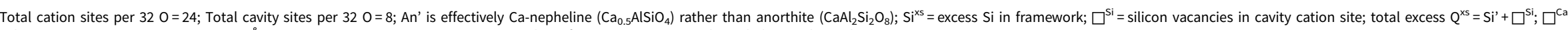
calcium vacancies in cavity cation site; ${ }^{\&} \mathrm{Si}$ atoms $=1 / 2 \mathrm{Si}_{2} \mathrm{O}_{4}$ to maintain same number of oxygen atoms in each nepheline end-member component.

Italics indicate equations used to calculate nepheline end-member components in analysed nephelines on a $32 \mathrm{O}$ basis 
based on the stoichiometric formula $\mathrm{CaAl}_{2} \mathrm{Si}_{2} \mathrm{O}_{8}$ and Barth defined the anorthite proportion as $5 \times \mathrm{Ca}$ (i.e. $\mathrm{Ca}+2 \mathrm{Al}+2 \mathrm{Si}$ ). Because $\mathrm{Ca}$ is absent in the $\mathrm{Ne}-\mathrm{Q}$ samples, zero $\mathrm{An}$ is reported for all five Ca-free samples, but the wrong An contents would have been reported if $\mathrm{Ca}$ had been present. Column 11 gives the correct equation for calculating the $\mathrm{An}$ ' ( $\mathrm{CaNe}$ ) component; this equation includes the cavity site vacancy associated with the Ca component.

The $\mathrm{Si}^{\mathrm{xs}}$ present in the tetrahedral framework of any nepheline solid solution is most simply calculated as the excess after the $\mathrm{Si}$ associated with the other nepheline end-members has been subtracted from the total number of $\mathrm{Si}$ atoms in the cell formula; note that one of the Blancher et al. (2010) calculations defined a value for the excess Si vacancy as $\square^{\mathrm{Si}}=\left(\mathrm{Si}^{\text {total }}-\mathrm{Al}\right) / 2$. For recalculating nepheline analyses Barth (1963) appears to have used the calculation $\mathrm{Q}^{\prime}=24-3 \mathrm{Na}-3 \mathrm{~K}-5 \mathrm{Ca}$ with the result shown in Table 1, column 12; note that Q' refers to the total excess Si molecule that takes account of the cavity site vacancies associated with both excess Si and Ca. For the top five rows in Table 1, column 12 shows that the total $\mathrm{Si}$ excesses are correctly calculated for all compositions. As expected, this calculation has provided the total Q' value, which includes both the actual $\mathrm{Si}^{\mathrm{xs}}$, which is a framework component, and the associated cavity cation site vacancies $\left(\square^{\text {Si }}\right)$. Using the numbers of framework Si atoms and associated $\mathrm{Si}$ vacancies defined in Table 1 the separate $\mathrm{Si}^{\mathrm{xs}}$ and $\square^{\mathrm{Si}}$ values are 8.34 and $4.17 \%$ for $\mathrm{Ne} 87.5 \mathrm{Q} 12.5,20$ and $10 \%$ for $\mathrm{Ne} 70 \mathrm{Q} 30,33.33$ and $16.66 \%$ for Ne50Q50 and 66.66, $33.33 \%$ for $100 \mathrm{Q}$. Thus $\square^{\mathrm{Si}}$ is exactly half of the excess $\mathrm{Si}^{\mathrm{xs}}$, though that has been defined for ideal nepheline stoichiometry. The Barth calculation only works here because no Ca component is present for this binary solid-solution series. Column 13 in Table 1 gives rigorous definitions of how to calculate excess $\mathrm{Si}$ values for Ca-bearing compositions. Thus this equation gives the correct total proportion for $\mathrm{Q}^{\mathrm{xs}}$. Another relationship given in Column 13 defines the vacancy proportion in the cavity cation sites directly: $\square^{\mathrm{Si}}=((8-\mathrm{Na}-2 \mathrm{Ca}) \times 100) / 8$ and this also provides the correct value for $\mathrm{Q}^{\mathrm{xs}}$. The most direct equation for calculating the total excess Si component is also shown in Column 13 where the total number of $\mathrm{Si}$ atoms minus the $\mathrm{Si}$ atoms contributed by the different nepheline components divided by 16 (the total tetrahedral cations) provides the required total Q; the fact that the number of excess Si atoms is normalised to 16 rather than 24 means that it is not necessary to consider the presence of any vacancies in the cavity sites. The equation $Q^{\prime}=((8-\mathrm{Na}-$ $2 \mathrm{Ca}) \times 100) / 24$ gives the proportion of $\square^{\mathrm{Si}}$ in the bulk composition equivalent to Q'/3, which leads to a framework excess Si proportion of $2 / 3 \mathrm{Q}$, as required for ideal stoichiometry. Finally, a value for the total excess $\mathrm{Si}$ content can also be calculated as $\left(\mathrm{Si}^{\text {total }}-\mathrm{Al}\right) \times 100 / 16$ as $\mathrm{Ne}$ is defined to have exact stoichiometry.

All these examples are defined with ideal nepheline stoichiometry, however, analyses of natural minerals would be subject to analytical error and the equation $\mathrm{Q}^{\mathrm{xs}}=\left(24-\mathrm{Si}^{\text {total }}-\mathrm{Al}-\mathrm{Na}-\right.$ $\mathrm{K}-2 \mathrm{Ca}) \times 100 / 8$ would provide a value for excess $\mathrm{Q}^{\mathrm{xs}}$ that would include most of the analytical errors (see below).

\section{Solid solutions in the system $\mathrm{Ne}-\mathrm{An}$}

At this stage to be consistent with published nomenclature the Ca-component will be referred to as An'. The five middle rows of Table 1 give atomic occupancy of compositions for $100 \mathrm{Ne}$ together with $90 \mathrm{Ne} 10,80 \mathrm{Ne} 20,50 \mathrm{Ne} 50 \mathrm{An}$ and 100An. Note that the vacancy associated with the presence of $\mathrm{Ca}$ exactly matches the $\mathrm{Ca}$ content (columns 2 and 4) and column 5 shows the $\mathrm{Al}$ associated with both $\mathrm{Ne}$ and $\mathrm{An}$ with the former value first. All the solid solutions would contain $8 \mathrm{Si}$ atoms per $32 \mathrm{O}$ (Table 1, column 6); no excess $\mathrm{Si}$ is present. The Ne contents are shown correctly in column 9. The data in column 10 shows how Barth (1963) calculated the Ca end-member; however, for the $\mathrm{Ne}-\mathrm{An}$ samples shown, the An proportions calculated are 0 , $8.33,16.66,41.67$ and $83.33 \%$ rather than $0,10,20,50$ and $100 \%$, respectively. Even though Barth (1963) stressed that the vacancy contents must be treated as 'cations' this was not followed in his calculation (see his tables 1 and 3). In column 11 the correct calculation is shown for the 24 cation basis that uses the term $6 \times$ Ca that includes the appropriate associated Ca vacancy and this gives the correct An' values; this calculation could also be defined as $\left(5 \times \mathrm{Ca}+\square^{\mathrm{Ca}}\right) \times 100 / 24$. Indeed, the Ca component can also be defined in terms of the cavity cation contents only, giving $\left(\mathrm{Ca}+\square^{\mathrm{Ca}}\right) \times 100 / 8$ that is the same as $2 \mathrm{Ca} \times 100 / 8$ as by definition for nepheline stoichiometry $\mathrm{Ca}=\square^{\mathrm{Ca}}$, and this step defines the naming of the simplest $\mathrm{Ca}$ component as $\square_{0.5}^{\mathrm{Ca}} \mathrm{Ca}_{0.5} \mathrm{AlSiO}_{4}$ (CaNe, unit cell $\left.\square_{4} \mathrm{Ca}_{4} \mathrm{Al}_{8} \mathrm{Si}_{8} \mathrm{O}_{32}\right)$. Data derived for apparent excess $\mathrm{Si}^{\mathrm{xs}}$ using the equation defined in column 12 shows that the deficiency for An' in column 10 is indeed accounted for by $\mathrm{Ca}$ vacancies, which would show as excess $\mathrm{Si}$ using Barth's calculation. For the $\mathrm{Ne}-\mathrm{An}$ series column 13 shows correctly that no excess $\mathrm{Si}$ is present.

Clearly the doubled $\mathrm{Ca}$ term involved in this calculation is related to the divalent character of $\mathrm{Ca}^{2+}$ that replaces two sodiums in cavity sites, which in turn is reflected in the fact that the endmember $\mathrm{Ca}_{0.5} \mathrm{AlSiO}_{4}$ has an atomic formula defined by half a $\mathrm{Ca}$ atom so that a given fraction of $\mathrm{Ca}$ atoms (in this case on a $4 \mathrm{O}$ basis) leads to a doubled $\mathrm{Ca}$ fraction for the $\mathrm{CaNe}$ component.

\section{Nephelines in the ternary system $\mathrm{Ne}-\mathrm{Q}-\mathrm{An}$}

The atom occupancy data for three ternary solid solution compositions are given in the lower part of Table 1. The first five columns have similar information to that provided above, though column 6 now shows the Si contents for both $\mathrm{Ne}$ and An (in that order). Column 9 again shows that the proportion of $\mathrm{Ne}$ can be calculated directly from the $\mathrm{Na}$ value either on a 24 cations or an 8 cavity cation basis. Column 10 again gives An' contents that are $1 / 6 \mathrm{Ca}$ too low whereas column 11 gives the correct An' values; the An' deficit shown in column 10 can again be identified as the $\square^{\mathrm{Ca}}$ values in column 12 . In addition, column 12 now shows that the total excess Si values are too high by that same amount and that the sum of the apparent $\mathrm{Si}^{\mathrm{xs}}$ and $\square^{\mathrm{Si}}$ now gives the correct $\mathrm{Q}^{\mathrm{xs}}$ content. It is clear that the Barth (1963) calculation only provides the total amount for the two vacancy types; Barth (1963) does suggest that the 'holes' could be considered as separate components, but this is not considered to be a reasonable suggestion as the An content would always be underestimated and the $\mathrm{Q}^{\mathrm{xs}}$ content overestimated. Equations to calculate the correct amounts for $\mathrm{Q}^{\mathrm{xs}}$ are shown in column 13 on both 24 and 8 cation bases; correct values would also be obtained using the relationships: $\quad(\mathrm{Si}-\mathrm{Al}) \times 100 / 16 ; \quad 1.5 \times \mathrm{Si}^{\mathrm{xs}} \times 100 / 24 ; \quad 0.5 \times \mathrm{Si}^{\mathrm{xs}} \times 100 / 8$; and $\square^{\mathrm{Si}} \times 100 / 8$.

\section{Dealing with other calculation protocols and nepheline components}

The Barth (1963) approach is followed for defining all of the nepheline end-member molecules on a 32 oxygen basis. Based 
on the section above, it is now clear that the main requirement in calculating molecular/atomic compositional parameters following ideal nepheline stoichiometry are that the vacancies associated with the entry of both $\mathrm{Ca}$ and excess $\mathrm{Si}$ into the structure must be counted as cavity cations. Naturally occurring nephelines contain significant amounts of kalsilite and the formulae developed so far will simply require the addition of a Ks component. Bannister and Hey (1931) and Dollase and Thomas (1978) stressed that high-quality analysed nephelines samples should have the stoichiometry parameters $\left(\mathrm{Si}+\mathrm{Al}+\mathrm{Fe}^{3+}\right)=16.000$ (within error) and $(\mathrm{Na}+\mathrm{K}+2 \mathrm{Ca})=\left(\mathrm{Al}+\mathrm{Fe}^{3+}\right)$ within error (see below). Depending on such considerations it is possible to standardise calculations by assuming exactly 24 total cations and exactly 8 cavity sites as required by symmetry and chemistry; alternatively, the former might be corrected to the analysed cation total for $\mathrm{Si}, \mathrm{Al}, \mathrm{Fe}, \mathrm{Ca}, \mathrm{Na}, \mathrm{K}$ plus vacancies (which should be close to 24 per $32 \mathrm{O}$ ) and for the analysed total for $\mathrm{Na}, \mathrm{K}, \mathrm{Ca}$ plus vacancies (which should be close to 8 per $32 \mathrm{O}$ ). Application of these rules to recalculating formulae for natural nephelines is assessed in the next section and will be applied to representative published analyses.

Other researchers [Peterson (1989) and Worley and Cooper (1995); Rossi et al. (1989); and Hamada et al. (2019)] have used different oxygen bases and/or end-member components. Thus Peterson (1989) used an 8 oxygen basis to define the end-member components $\mathrm{Ne}\left(\mathrm{Na}_{2} \mathrm{Al}_{2} \mathrm{Si}_{2} \mathrm{O}_{8}\right)$, Ks $\left(\mathrm{K}_{2} \mathrm{Al}_{2} \mathrm{Si}_{2} \mathrm{O}_{8}\right), \mathrm{Nf}\left(\mathrm{Na}_{2} \mathrm{Fe}_{2}^{3+}\right.$ $\left.\mathrm{Si}_{2} \mathrm{O}_{8}\right)$ (i.e. iron nepheline), $\mathrm{An}\left(\mathrm{CaAl}_{2} \mathrm{Si}_{2} \mathrm{O}_{8}\right), \mathrm{Qz}\left(\mathrm{Si}_{4} \mathrm{O}_{8}\right)$, and $\mathrm{Cn}$ $\left(\mathrm{Al}_{16 / 3} \mathrm{O}_{8}\right)$; the last component (in effect a theoretical corundum content) was introduced in an attempt to account for analyses so rich in $\mathrm{Na}$ and $\mathrm{K}$ that deficiencies were reported for both $\mathrm{Al}$ and Si. Rossi et al. (1989) used a $32 \mathrm{O}$ basis and end-members $\mathrm{K}_{2} \mathrm{Na}_{6} \mathrm{Al}_{8} \mathrm{Si}_{8} \mathrm{O}_{32}, \quad \mathrm{Na}_{2} \mathrm{Na}_{6} \mathrm{Al}_{8} \mathrm{Si}_{8} \mathrm{O}_{32}$ and $\mathrm{Ca} \square^{\mathrm{Ca}} \mathrm{Na}_{6} \mathrm{Al}_{8} \mathrm{Si}_{8} \mathrm{O}_{32}$ and, more recently, Blancher et al. (2010) reported nepheline endmembers based on 4-oxygen cells as $\mathrm{NaAlSiO}_{4}, \mathrm{KAlSiO}_{4}$, $\square^{\mathrm{Si}} \mathrm{Si}_{2} \mathrm{O}_{4}$, and $\square_{0.5}^{\mathrm{Ca}} \mathrm{Ca}_{0.5} \mathrm{AlSiO}_{4}$. Finally, Hamada et al. (2019) also reported nepheline end-members based on 4-oxygen cells

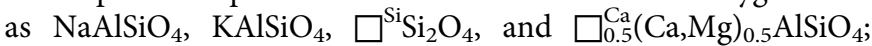
note that the last component assumes that $\mathrm{Mg}$ occupies the cavity sites that is considered to be unlikely (see above). Dealing with the same end-member compositions standardised to any chosen number of oxygens would provide the same results, however application of the Peterson and Hamada approaches could lead to either problems or possibly errors; such problems are discussed in the following section.

\section{Assessment of igneous rock nepheline component calculations.}

\section{Criteria for assessing analysis reliability and end-member calculation protocols}

Section S.3 in the supplementary files gives a more detailed treatment of how earlier workers have assessed the reliability of nepheline analyses. In this paper the approaches of Bannister and Hey (1931) and Dollase and Thomas (1978) have been extended to show reliable nepheline analyses must have coupled $\Delta \mathrm{Al}^{\text {cavity cation }}$ $\left[\Delta\left(\left\{\mathrm{Al}+\mathrm{Fe}^{3+}\right\}-\{\mathrm{Na}+\mathrm{K}+2 \mathrm{Ca}\}\right)\right]$ and $\Delta \mathrm{T}^{\text {charge }}\left[\left\{\left(\mathrm{Al}+\mathrm{Fe}^{3+}\right) \times 3+\right.\right.$ $(\mathrm{Si}+\mathrm{Ti}) \times 4\}-\{16 \times$ measured mean tetrahedral charge $\}]$ parameters. For the analyses given by Bannister and Hey (their table 1) $\Delta \mathrm{Al}^{\mathrm{cc}}$ would have a mean value -0.011 and $\Delta \mathrm{T}^{\text {charge }}$ a mean value of -0.017 . The average $\Delta \mathrm{Al}^{\mathrm{cc}} / \Delta \mathrm{T}^{\text {charge }}$ ratio for their samples is 1.17 (range 1.01 to 1.24 ); the $\Delta \mathrm{Al}^{c \mathrm{cc}} / \Delta \mathrm{T}^{\text {charge }}$ ratio must reflect a
$\mathrm{Si} / \mathrm{Al}$ ratio $>1$ as expected for natural nephelines. For exact nepheline stoichiometry (unit cell 32 oxygens, $16 \mathrm{~T}$ atoms, 8 cavity sites, $\mathrm{Si}=\mathrm{Al}) \Delta \mathrm{Al}^{\mathrm{cc}}$ and $\Delta \mathrm{T}^{\text {charge }}$ both equal 0 . For departures from these 'ideal' values, delta parameters would be coupled with either positive or negative values, though both should have the same sign and have similar values in the absence of significant analytical errors. On the basis of the formulation used to define the delta values, an increase of the $\mathrm{T}$ site cation total to $>16.00$ would lead to negative $\Delta \mathrm{T}^{\text {charge }}$ values (coupled to negative $\left.\Delta \mathrm{Al}^{\mathrm{cc}}\right)$ and if the $\mathrm{T}$ cation site total is $<16.00$ the $\Delta \mathrm{T}^{\text {charge }}$ would be positive $\left(c f .+\right.$ ve $\left.\Delta \mathrm{Al}^{\mathrm{cc}}\right)$.

More than half of the compositions discussed by Bannister and Hey (1931) show an excess of cavity cations over trivalent framework components. This excess positive charge could be neutralised by the Si component of the framework (cf. the natural mineral natrosilite, $\beta-\mathrm{Na}_{2} \mathrm{Si}_{2} \mathrm{O}_{5}$ ) but that implies breaking $\mathrm{Si}-\mathrm{O}-\mathrm{Si}$ framework bonds). However, it is also possible that the charge for a small excess alkali content could be neutralised by the presence of large anions (e.g. $\mathrm{CO}_{3}^{2-}, \mathrm{Cl}$ ) as in cancrinites (see Supplementary material, section S.3); this is dealt with in more detail below.

The fact that natural nephelines mostly have $\mathrm{Si} / \mathrm{Al}$ ratios $>1.0$ has been accounted for by the presence of a feldspar-like component and the same could be said for an anhydrous analcime component $\left(\mathrm{NaAlSi}_{2} \mathrm{O}_{6}\right)$; such solid solutions would of course have stuffed tridymite frameworks (see above). Using 'nepheline' 32 oxygen unit-cell stoichiometry, $\Delta \mathrm{Al}^{\mathrm{cc}}$ and $\Delta \mathrm{T}^{\text {charge }}$ parameters for ideal $\mathrm{NaAlSiO}_{4}, \mathrm{NaAlSi}_{2} \mathrm{O}_{6}$ and $\mathrm{NaAlSi}_{3} \mathrm{O}_{8}$ should have zero values for both delta parameters for each of these three endmembers with the different $\mathrm{Si} / \mathrm{Al}$ ratios of 1, 2 and 3, respectively. A ratio for $\Delta \mathrm{Al}^{\mathrm{cc}} / \Delta \mathrm{T}^{\text {charge }}$ cannot be calculated for zero delta values, however by allowing a very small degree of nonstoichiometry for the $\mathrm{Si}, \mathrm{Al}$ or $\mathrm{Na}$ components, the estimated $\Delta \mathrm{Al}^{\mathrm{cc}} / \Delta \mathrm{T}^{\text {charge }}$ ratios are close to $1.143,1.091$ and 1.067 , respectively (Supplementary section S.3); analyses of natural minerals confirm these $\Delta \mathrm{Al}^{\mathrm{cc}} / \Delta \mathrm{T}^{\text {charge }}$ ratios (Table S.1). Note that the size of the delta values relative to zero reflects their departure from ideal nepheline stoichiometry. Thus compositional variations within natural nephelines would be expected to show at least this range of $\Delta \mathrm{Al}^{\mathrm{cc}} / \Delta \mathrm{T}^{\text {charge }}$ ratios for acceptable nepheline analyses. At this stage, the Dollase and Thomas (1978) approach of defining a range of \pm 0.25 for both $\Delta \mathrm{Al}^{\mathrm{cc}}$ and $\Delta \mathrm{T}^{\text {charge }}$ will be adopted for now, nevertheless the importance of these values being coupled is stressed. In addition, the $\Delta \mathrm{Al}^{\mathrm{cc}} / \Delta \mathrm{T}^{\text {charge }}$ range from 1.0 to 1.2 is used here to define acceptable analyses.

On the basis of these criteria, the compositions shown in table 6 of Deer et al. (2004) have 32 of 39 analyses falling within this acceptable range for both $\Delta \mathrm{Al}^{\text {cc }}$ and $\Delta \mathrm{T}^{\text {charge }} ; 25$ of the 39 analyses have $\Delta \mathrm{Al}^{\mathrm{cc}} / \Delta \mathrm{T}^{\mathrm{charge}}$ ratios within the range 1.0 to 1.2 (22 of these in the narrow range 1.120 to 1.142 ), and 33 of the analyses have $\mathrm{T}$ atom totals within the range 15.9 to 16.1 atoms per $32 \mathrm{O}$. Any major differences between the two delta parameters must reflect either non-stoichiometry and/or significant analytical errors for one or more of the analytical values.

Table 2 summarises the equations used in this paper to calculate nepheline end-member proportions on the basis of $32 \mathrm{O}$ cell formulae and on the simple formulae: $\mathrm{NaAlSiO}_{4}(\mathrm{Ne}), \mathrm{KAlSiO}_{4}$ (Ks), $\square_{0.5}^{\mathrm{Ca}} \mathrm{Ca}_{0.5} \mathrm{AlSiO}_{4}(\mathrm{CaNe})$, and $\square^{\mathrm{Si}} \mathrm{Si}_{2} \mathrm{O}_{4}$ (Q'). Equations 1 and 2 define the excess $\mathrm{Si}\left(\mathrm{Si}^{\mathrm{xs}}\right)$ and, following Barth (1963), equations 3, 4, 5 and 6 define the proportions of $\mathrm{Q}^{\mathrm{xs}}, \mathrm{Ne}, \mathrm{Ks}$, and $\mathrm{CaNe}$ taking account of essential vacancies in the cavity cation sites. Equation 7 provides another estimate of total excess silica 
Table 2. Equations for calculations based on a 32 oxygen nepheline structure unit cell.

\begin{tabular}{|c|c|c|}
\hline Basis & Formulae & $\begin{array}{c}\text { Equation } \\
\text { number }\end{array}$ \\
\hline Excess Si Si ${ }^{x s}$ & $\begin{array}{l}\mathrm{Si}^{\mathrm{xs} 1}=\mathrm{Si}^{\text {total }}-\mathrm{Na}-\mathrm{K}-2 \mathrm{Ca} \\
\mathrm{Si}^{\mathrm{xs2}}=\mathrm{Si}^{\text {total }}-\mathrm{Al}\end{array}$ & $\begin{array}{l}1 \\
2\end{array}$ \\
\hline Total sites, 24 & $\begin{array}{l}\mathrm{Q}^{\times \mathrm{s}} \%=(24-3 \mathrm{Na}-3 \mathrm{~K}-6 \mathrm{Ca}) \times 100 / 24 \\
\mathrm{Ne} \%=3 \mathrm{Na} \times 100 / 24 \\
\mathrm{Ks} \%=3 \mathrm{~K} \times 100 / 24 \\
\mathrm{CaNe} \%=6 \mathrm{Ca} \times 100 / 24 \\
\mathrm{Ks} M \%=6 M^{2+} \times 100 / 24\end{array}$ & $\begin{array}{r}3 \\
4 \\
5 \\
6 \\
14\end{array}$ \\
\hline $\begin{array}{l}\text { Framework sites } \\
\text { only, } 16\end{array}$ & $\begin{array}{l}Q^{S i} \%=S^{x s 1} \times 100 / 16 \\
Q^{(S i-A l)}=S i^{x s 2} \times 100 / 16\end{array}$ & $\begin{array}{l}7 \\
8\end{array}$ \\
\hline Cavity sites only, 8 & $\begin{aligned} \mathrm{Q}^{\mathrm{cav1}} \% & =(8-\mathrm{Na}-\mathrm{K}-2 \mathrm{Ca}) \times 100 / 8 \\
\mathrm{Q}^{\mathrm{cav} 2} \% & =\left(24-\text { total } \mathrm{Si}-\mathrm{Al}-\mathrm{Fe}^{3+}-\mathrm{Na}-\right. \\
\mathrm{K} & -2 \mathrm{Ca}) \times 100 / 8 \\
\mathrm{Ne} \% & =\mathrm{Na} \times 100 / 8 \\
\mathrm{Ks} \% & =\mathrm{K} \times 100 / 8 \\
\mathrm{CaNe} \% & =2 \mathrm{Ca} \times 100 / 8\end{aligned}$ & $\begin{array}{r}9 \\
10 \\
11 \\
12 \\
13\end{array}$ \\
\hline
\end{tabular}

$\left(\mathrm{Q}^{\mathrm{Si}}\right)$ that is based on a $16 \mathrm{~T}$-atom framework; note that the actual per cent of $\mathrm{Si}$ in the framework is given by $\mathrm{Si}^{\mathrm{xs}}=\left(\mathrm{Si}_{\text {total }}-\mathrm{Na}-\mathrm{K}-\right.$ $2 \mathrm{Ca}) \times 100 / 24$ and the amount of vacancy associated with the excess Si component $\square^{\mathrm{Si}}=(8-\mathrm{Na}-\mathrm{K}-2 \mathrm{Ca}) \times 100 / 24$. The relative proportions of these $\mathrm{Si}$ parameters are $3: 2: 1$, which is fixed by the ideal nepheline stoichiometry and structural symmetry. Equation 8 defines a fourth estimate for the total excess silica $\left(\mathrm{Q}^{(\mathrm{Si}-\mathrm{Al})}\right)$ and this is also defined on a $16 \mathrm{~T}$-atom framework; this parameter does not depend on the reliability of analyses for the cavity cations.

Of course, all of these end-member parameters can also be defined from the occupancy of the cavity cation sites alone (equations 9,11, 12 and 13) and these provide the same numbers as equations 3, 4, 5 and 6 . Equation 10 provides an additional estimate of the total excess silica proportion $\left(Q^{\text {cav2 }}\right)$ based on the total cations; this value uses the proportion of vacancies in the cavity site corrected for the presence of divalent $\mathrm{Ca}$. For ideal stoichiometry all calculated total excess silica values should be identical; different values will depend on the scale of non-stoichiometry and/or the presence of analytical errors. In addition the second value defined for $Q^{\text {cav }}$ would be influenced by any analytical error for $\mathrm{Al}$ (equation 10). Blancher et al. (2010) calculated excess $\mathrm{Q}$ simply as $0.5\left(\mathrm{Si}^{\text {tot }}-\mathrm{Al}\right) \times 100 / 8$ (cf. Table 2, equation 8) whereas their most complex method involved using least squares fitting to minimise the function

$$
\begin{aligned}
R^{2}= & (\mathrm{Na}-\mathrm{Ne})^{2}+(\mathrm{K}-\mathrm{Ks})^{2}+(\mathrm{Ca}-\mathrm{An} / 2)^{2} \\
& +(\mathrm{Al}-\mathrm{Na}-\mathrm{Ks}-\mathrm{An})^{2}+\left(\mathrm{Si}-\mathrm{Na}-\mathrm{Ks}-\mathrm{An}-2 \mathrm{Q}^{\prime}\right)
\end{aligned}
$$

where $\mathrm{Na}, \mathrm{K}, \mathrm{Ca}, \mathrm{Al}$, and $\mathrm{Si}$ are numbers of atoms per 4 oxygens and $\mathrm{Ne}, \mathrm{Ks}, \mathrm{An}$ and Q' are mole fractions of the chosen endmembers per $4 \mathrm{O}$.

The values calculated here for the chosen nepheline endmembers $\mathrm{CaNe}\left(\mathrm{An}\right.$ ') and total excess $\mathrm{Si}\left(\mathrm{Q}^{\mathrm{xs}}\right)$ for the 39 analyses quoted by Deer et al. (2004, their table 6) are given in the Supplementary material (Table S.2; these are referred to here as 'DHZ values') and show significant differences to those given in the original source. For Ca-free nepheline analyses the $\mathrm{CaNe}$ and $\mathrm{Q}^{\mathrm{xs}}$ values calculated here match those in the original source, but for Ca-bearing samples the new calculations generally have higher $\mathrm{CaNe}$ and lower excess Q values than the $\mathrm{DHZ}$ values. Thus, it is probable that the DHZ values were calculated using the Barth (1963) procedure where their An content determination did not take account of the vacancy associated with the presence of $\mathrm{Ca}$; this results in An contents that are $1 / 6 \mathrm{Ca}$ too low and excess $\mathrm{Q}^{\mathrm{xs}}$ values that are $1 / 6 \mathrm{Ca}$ too high. Tables S.2 (Supplementary file) and Table 4 (main paper) also show values for a new nepheline end-member defined by its content of a divalent tetrahedral component of formula $\mathrm{K}_{8} M_{4}^{2+} \mathrm{Si}_{12} \mathrm{O}_{32}$; note that $M=\mathrm{Mg}+\mathrm{Fe}^{2+}+\mathrm{Mn}$ (see above) where $\mathrm{Mg}$ tends to be the largest divalent component reported in natural nephelines. On the basis of the simplest formula for this component of $\mathrm{KM}_{0.5}^{2+} \mathrm{Si}_{1.5} \mathrm{O}_{4}$ (8 per equivalent nepheline unit cell) the proportion of the KsM molecule would be based on 0.5 atoms of $M^{2+}$ and calculated from $\% \mathrm{Ks} M=6 M \times$ $100 / 24$ (Table 2, equation 14). It is probable that the most reliable data for this component comes from electron microprobe analyses (e.g. Dawson et al., 1995; analysis \# 34) as the older 'wet' chemical analyses of mineral separates might have such components reflecting the presence of impurity mineral phases. Calculation of the excess $\mathrm{Q}^{\mathrm{xs}}$ is not affected by incorporation of this KsM component as the total $\mathrm{K}$, Si-equivalent is subtracted from the analysed $\mathrm{Si}$.

The end-member molecules calculated for natural nephelines by Peterson (1989) give values for both excess and deficient $\mathrm{Si}$ and $\mathrm{Al}$ molecules which, based on the $32 \mathrm{O}$ cell used here, have the ideal formulae $\square_{8} \mathrm{Si}_{16} \mathrm{O}_{32}$ and $\square_{2.666} \mathrm{Al}_{21.333} \mathrm{O}_{32}$; the percentage values for these are simply calculated as [(total $\mathrm{Si}-\mathrm{Na}-\mathrm{K}-$ $2 \mathrm{Ca}) \times 100] / 16$ and $[(\mathrm{Al}-\mathrm{Na}-\mathrm{K}-2 \mathrm{Ca}) \times 100] / 21.333$, respectively. The concept of an excess or deficient content of $\mathrm{Al}$ $\left(+\mathrm{Fe}^{3+}\right)$ compared with that associated with $\mathrm{Na}, \mathrm{K}$ and $\mathrm{Ca}$ is not straightforward crystal chemically. Analytical error is probably an important factor with an excess of $\mathrm{Al}$ related to alkali 'loss' in the electron microprobe if a defocussed beam or raster scan is not used (Morgan and London, 2005; Henderson and Pierozynski, 2012); a lower-than-normal beam current is also essential. If the analysis conditions are optimal, an excess endmember alumina $\left(\mathrm{Al}_{2} \mathrm{O}_{3}\right)$ content implies that this component has a framework structure with both tetrahedral and octahedral Al sites, perhaps similar to an anhydrous, hexagonal kappa- or chi-alumina phase (Okumiya and Yamaguchi, 1971; Levin and Brandon, 1998). Though the presence of a small amount of such a molecule in solid solution might be possible, the occurrence of significant interstitial octahedral $\mathrm{Al}$ cations is more problematical. The presence of some $\mathrm{CaAl}_{2} \mathrm{O}_{4}$ in solid solution might be possible (Goldsmith, 1949; Donnay et al., 1959) but that would not explain a deficiency in the $\Delta(\mathrm{Al}$ - cations) parameter. Perhaps it is possible that a small amount of an alkali-rich and Al- and Si-poor alteration phase is present in such natural nephelines. The most probable alteration mineral would be cancrinite as this has a hexagonal structure with six-rings of tetrahedra similar to those of nepheline, although the linkages of these units are different in the two mineral groups. The general formula for the cancrinite group is $(\mathrm{Na}, \mathrm{K})_{6} \mathrm{Ca}_{2}\left[(\mathrm{Al}, \mathrm{Si})_{12} \mathrm{O}_{24}\right]\left(\mathrm{CO}_{3}, \mathrm{SO}_{4}, \mathrm{Cl}\right.$, $\mathrm{OH})_{2} \cdot n \mathrm{H}_{2} \mathrm{O}$, which on a $32 \mathrm{O}$ basis would be $(\mathrm{Na}$, $\mathrm{K})_{8} \mathrm{Ca}_{2.66}\left[(\mathrm{Al}, \mathrm{Si})_{16} \mathrm{O}_{32}\right]\left(\mathrm{CO}_{3}, \mathrm{SO}_{4}, \mathrm{Cl}, \mathrm{OH}\right)_{2.66} \cdot n \mathrm{H}_{2} \mathrm{O}$. This is compositionally similar to nepheline but is structurally different with the extra $\mathrm{Na}, \mathrm{Ca}$ and large anions occupying 'cancrinite cages' and large continuous channels (Deer et al., 2004; their figure 245); note that entry of any extra Ca with its anion would not be associated with entry of an equivalent vacancy in a cavity site. 
Some cancrinite species are possibly stable at high temperatures (Larsen and Foshag, 1926) and Edgar (1964). Indeed, Sirbescu and Jenkins (1999) have investigated the system $\mathrm{Na}_{2} \mathrm{O}-\mathrm{CaO}-$ $\mathrm{Al}_{2} \mathrm{O}_{3}-\mathrm{SiO}_{2}-\mathrm{CO}_{2}-\mathrm{H}_{2} \mathrm{O}$ at $2 \mathrm{kbar}$ and reported a triple point involving nepheline, cancrinite and silicate melt at $\sim 950^{\circ} \mathrm{C}$. It appears that no-one has studied the possibility of some solid solution between nepheline and cancrinite.

\section{A new database of published nepheline analyses}

For this paper a database of 310 published nepheline analyses as up-to-date as possible has been assembled. Table 3 shows a list of source publications and the following treatment is based on these data, together with other papers referred to in the text. The summary comments made in Table 3 are supplemented in the following text. The representative published analyses shown in Table 4 were chosen to reflect nepheline compositions from a range of magmatic rock types where the original authors might have used different protocols for calculating $\mathrm{CaNe}$ (An') and excess Q'. Thus, Table 4 shows the calculations of the formula units based on the 32 oxygen cell; the CaNe component was defined by multiplying the number of $\mathrm{Ca}$ atoms by 6 and the total $\mathrm{Q}^{\mathrm{xs}}$ is calculated from equation 3 of Table 2; an excess $Q$ ' value based on the total $\mathrm{Si}$ atoms $\left(\mathrm{Q}^{\mathrm{Si}}\right)$ is calculated using equation 7 of Table 2. Table 4 also gives two further estimates for excess Q', the third defined above as $Q^{\text {cav }}$ (equation 9 or 10) and the fourth which is based on the excess of $\mathrm{Si}$ over that for $\mathrm{Al}$ alone $\left(\mathrm{Q}^{(\mathrm{Si}-\mathrm{Al})}\right.$; Table 2 equation 8$)$. All four excess $\mathrm{Q}$ estimates should be similar for acceptable analyses and would have identical values for ideal nepheline stoichiometry. Fourteen of the 16 analyses shown in Table 4 have $\Delta \mathrm{Al}^{\mathrm{cc}}$ and $\Delta \mathrm{T}^{\text {charge }}$ within \pm 0.25 and represent 'acceptable' analyses, whereas compositions 15 and 17 fall outside the acceptable range. In addition, 13 have $\Delta \mathrm{Al}^{\mathrm{cc}}$ / $\Delta \mathrm{T}^{\text {charge }}$ within the narrow range 1.07 to 1.14 with analyses 13 , 15 and 18 having significantly lower values of $0.65,0.73$ and 0.75 , respectively (see below). Significant differences between the four Q' values mark a departure from ideal stoichiometry although analytical errors could be partly responsible; as a 'rule of thumb', a $\Delta \mathrm{Al}^{\mathrm{cc}}$ value of 0.25 would lead to a difference of at least $10 \%$ (relative) between the values for $\mathrm{Q}^{\mathrm{xs}}$ and $\mathrm{Q}^{\mathrm{Si}}$.

In Table 4, column 1 shows data from Barth (1963) for his Sample 1 (his tables 2 and 4); calculations of atoms per 32 oxygens only differ slightly from his, presumably reflecting the different atomic weights used. Note that Barth recorded the proportion of 'holes' (cavity site vacancies), which includes components from both the presence of $\mathrm{Ca}$ and excess Si. Data in column 2 show the new calculations of molecular end-members for the total CaNe and $\mathrm{Q}^{\mathrm{xs}}$, which both include their vacancy contributions. It is clear that the total for $\mathrm{CaNe}$ and $\mathrm{Q}^{\mathrm{xs}}$ matches Barth's total for An'+ Q'+'holes'. The next column shows data for the hypothetical 70Ne-20Q-10CaNe composition; as expected the ideal nepheline stoichiometry for this composition and the reliability of the equations used for calculating composition parameters deliver zero values for the $\Delta \mathrm{Al}^{\mathrm{cc}}$ and $\Delta \mathrm{T}^{\text {charge }}$ terms and identical values for the four different ways of calculating excess $Q$ values. The cation total is 22 atoms leaving 2 of the 24 sites vacant consisting of 0.4 vacancies associated with $\mathrm{Ca}$ and 1.6 with the excess Q'. These vacancies together with the cavity cations $\mathrm{Na}$ and $\mathrm{Ca}$ are located in the 8 cavity sites and give occupancies for $\mathrm{CaNe}$ of $(0.4 \mathrm{Ca}$ $\left.+0.4 \square^{\mathrm{Ca}}\right) \times 100 / 8=10 \%$ and for $\mathrm{Q}^{\mathrm{xs}}$ of $1.5 \square^{\mathrm{Si}} \times 100 / 8=20 \%$, which are identical to the values shown for the same parameters in Table 4 reflecting the ideal stoichiometry for this composition.
Analysis 4 is for a disequilibrium synthetic nepheline (Dollase and Thomas, 1978); analyses 5, 6 and 7 are for nephelines in alkaline basaltic rocks (respectively: Henderson and Gibb, 1983, Gibb and Henderson, 1978, Wilkinson and Hensel, 1994), and analysis 11 is from a nepheline syenite (Dollase and Thomas, 1978). For these five samples calculations all show high $\mathrm{Q}^{\mathrm{xs}}$ contents but these are $\sim 1 / 3$ smaller than those quoted in the original papers; in addition the CaNe content given here for analysis 5 is approximately double the An value quoted by Henderson and Gibb (1983) (see earlier comments). Clearly the present calculations use a different procedure and it seems that the higher $\mathrm{Q}^{\mathrm{xs}}$ and lower $\mathrm{CaNe}$ values obtained in the original publications were most probably obtained using the following procedures:

$$
\begin{aligned}
& \% \text { excess } \mathrm{Qz}=\left(\mathrm{Si}_{\text {total }}-\mathrm{Na}-\mathrm{K}-2 \mathrm{Ca}\right) \\
& \times 100 /\left[\mathrm{Na}+\mathrm{K}+\mathrm{Ca}+\left(\mathrm{Si}_{\text {total }}-\mathrm{Na}-\mathrm{K}-2 \mathrm{Ca}\right)\right] \\
& \% \mathrm{An}(\mathrm{CaNe})=\mathrm{Ca} \times 100 /\left(\mathrm{Si}_{\text {total }}-\mathrm{Na}-\mathrm{K}-2 \mathrm{Ca}\right)
\end{aligned}
$$

The original An value calculated is much smaller than that calculated here for $\mathrm{CaNe}$ because the vacancy associated with $\mathrm{Ca}$ was not included in the numerator whereas the denominators in both equations are too small because the total excess Si was subtracted instead of half of this value, which defines the vacancy in the cavity sites related to the excess $\mathrm{Si}$ present (i.e. $\square^{\mathrm{Si}}=\mathrm{Si}^{\mathrm{xs}} / 2$ ). Note that for small Ca contents the denominator is little different from the value for total $\mathrm{Si}$ atoms per $32 \mathrm{O}$. By following a procedure similar to the early stages of calculating a CIPW norm, and taking the residual mole proportion of $\mathrm{SiO}_{2}$ after subtracting the $\mathrm{Si}$ components contained in $\mathrm{Ne}, \mathrm{Ks}$ and $\mathrm{An}$, and combining this with moles of $\mathrm{Ne}\left(2\right.$ moles from $\left.\mathrm{Na}_{2} \mathrm{O}\right)$, Ks ( 2 moles from $\mathrm{K}_{2} \mathrm{O}$ ), and An (1 mole from $\mathrm{CaO}$ ), provides very similar molar $\mathrm{Ne}-\mathrm{Ks}-\mathrm{Q}^{\mathrm{xs}}$ values to those reported by Dollase and Thomas (1978). Using the new calculations, the effect of departure from nepheline stoichiometry using the data in columns 4 and 5 can be considered as follows; for sample $4 \Delta \mathrm{Al}^{\mathrm{cc}}=0.041$; $\mathrm{Q}^{\mathrm{xs}}=22.1$; $\mathrm{Q}^{\mathrm{Si}}=21.9$. Equivalent values for column 5 are: $0.19,17.33$ and 16.5 , respectively; the very small $\Delta \mathrm{Al}^{\mathrm{cc}}$ for sample 4 is matched by the almost identical excess $\mathrm{Q}$ values, whereas the larger $\Delta \mathrm{Al}^{\mathrm{cc}}$ for sample 5 leads to a $\mathrm{Q}^{\mathrm{xs}} v s$. $\mathrm{Q}^{\mathrm{Si}}$ difference of $\sim 5.5 \%$ of the excess Si present reflecting a combination of analytical error and/or minor non-stoichiometry in the latter sample.

The nepheline compositions shown in columns 7 and 8-14 include analyses from rock types varying from pyroxenites (8) to theralites $(7,9)$ to nepheline syenites $(10-14)$. The published endmember data for two samples (columns 8 and 12) were given as wt.\% values but the mol.\% values given here are directly comparable to these values and simply reflect the different molecular masses of the end-members (assuming a molecular weight of 120 for the excess Si component). For nepheline analyses published by the Mitchell and Melluso groups the data presented here show similar nepheline end-member compositions to the published values suggesting that the calculation protocols are similar and reliable. However, differences for other samples, particularly for the $\mathrm{Q}^{\mathrm{xs}}$ values, are difficult to reconcile with the analytical data published, but excess Q' values from Worley and Cooper (1995), Wittke and Holm (1996), Brotzu et al. (1997) and Zhu et al. (2016) match $\mathrm{Q}^{\mathrm{Si}}$ better than $\mathrm{Q}^{\mathrm{xs}}$ values. For this range of natural rock data $\mathrm{CaNe}$ and $\mathrm{Q}^{\mathrm{xs}}$ values vary from 0 to $12.9 \%$ and $\sim 3$ to $20 \%$ though there does not seem to be a clear relationship with 
Table 3. Summary of papers dealing with nepheline compositions in natural rocks.

\section{Source}

Dollase and Thomas (1978)

Henderson and Gibb (1983)

Wilkinson and Hensel (1994)

\section{Source}

Mitchell and Platt (1979b) Intercumulus nepheline in malignite. $\Delta \mathrm{Al}-0.05$ to $-0.37, \Delta^{\text {atoms }} 0.08$ to 0.47 ; wt. $\%$ end-members calc with vacancies for Ca-phase and $Q^{\mathrm{xs}}$ which is consistent with nepheline stoichiometry.

Mitchell and Platt (1982) Early-formed and evolved nepheline syenites, pegmatites, and recrystallised syenite. Typically altered to natrolite. Stoichiometry reported wt. $\%$. $\Delta \mathrm{Al}-0.14$ to +0.13 , 2 samples with -0.34 and $+0.42 ; \Delta^{\text {atoms }} 0.55$ to 0.94 .

Dawson et al. (1995)

Melluso et al. (1996) Oldoinyo Lengai ijolite, nepheline syenite xenoliths. Nepheline analys
phase $\Delta \mathrm{Al}-0.80$ to $+0.29, \Delta^{\text {atoms }}-0.58$ to -0.010 ; wt. $\%$ Ne, Ks, Q.

Calcic alkaline lavas and dykes. Groundmass nepheline associated melilite and haüyne. $\Delta \mathrm{Al}-0.06$ to +0.08 , also -1.9 (see text) and +0.30 , $\Delta^{\text {atoms }} 0.20$ to 0.94 wt.\%. Ne, Ks, Q with $\mathrm{Q}^{\mathrm{xs}}$ calculated including vacancy; match the wt. calculations. No Ca end-member given. Silica-undersaturated syenites. Nepheline analyses. $\Delta \mathrm{Al}+0.14$ to $1.67, \Delta^{\text {atoms }} 0.16$ to 1.37 . Generally poor stoichiometry low alkalis? wt. $\%$ NeKsQ $Q^{\times s}$ match our wt.\% stoichiometry nepheline calculations.

Brotzu et al. (1997)

Zhu et al. (2016)

Melluso et al. (2012)

\section{Source} Foyaitic and granular nepheline syenite $\Delta \mathrm{Al}-0.20$ to $+0.14, \Delta^{\text {atoms }}-0.06$ to 0.66 ; wt.\% NeKsQ' end-members match our wt. $\%$ values Ultramafic to nepheline syenite 'ring' complex. $\Delta \mathrm{Al}$ neph analyses -0.23 to $+0.09, \Delta^{\text {atoms }} 0.04$ to 1.15 . Wt. $\%$ NeKs ${ }^{\mathrm{xs}}$ match our calculations. Good nepheline stoichiometry.

\section{Molecular \% nepheline end-members}

Mitchell and Platt (1979a) Xenolith in nepheline syenite, nepheline intergrown feldspar $\Delta \mathrm{Al}-0.10$ to $+0.41, \Delta^{\text {atoms }} 0.76$ to 1.10 . Mol.\% Ne,FeNe,Ks,An, $\mathrm{Q}^{\mathrm{xs}}$ match calculations in this work; $\square \mathrm{Ca}$, $\square \mathrm{Si}$ used.

Donaldson et al. (1987) Microprobe analyses (beam current $4 \mathrm{nA}$, spot 1-2 $\mu \mathrm{m}$ ) of nepheline phenocrysts from nephelinite and phonolite. $\Delta \mathrm{Al}+0.042$ to +0.54 ; $\Delta^{\text {atoms }}+0.25$ to +0.85 . Nepheline partly altered to veins/patches of zeolite/analcime. Phonolitic nephelinite has microphenocrysts $(0.5 \mathrm{~mm})$ of vishnevite-cancrinite.

Flohr and Ross (1990) Alkaline ring complex. $\Delta \mathrm{Al}-0.2$ to $+0.52, \Delta^{\text {atoms }} 0.27$ to 1.04 poor stoichiometry. Mol.\% end-members Ne,FeNe,Ks, An, Q', match ours; $\square \mathrm{Ca}$ and $\square \mathrm{Si}$ included in stoichiometry nepheline calculations.

Worley and Cooper (1995) Nepheline syenite complex. $\Delta \mathrm{Al}-0.24$ to $+0.22, \Delta^{\text {atoms }} 0.23$ to 0.56 . Mol. end-members same as Peterson plus Sr and Ba molecules. Good calculations.

Trupia and Nicholls Nephelinites, groundmass nepheline $\Delta \mathrm{Al}-1.18$ to $+0.04, \Delta^{\text {atoms }} 0.41$ to 1.92 ; although stoichiometry claimed, poor for groundmass (1996)

Wittke and Holm (1996)

Conceição et al. (2009)

Blancher et al. (2010) samples. Low Al?

ljolite and nepheline monzonite. $\Delta \mathrm{Al}-0.07$ to $+0.72, \Delta^{\text {atoms }} 0.53$ to 1.22 . Some poor stoichiometry, $\mathrm{Q}^{\mathrm{xs}}$ suspect. Unclear re calculations High Ca but no end-member calculations.

Nepheline syenite, $\Delta \mathrm{Al}-0.03$ to $+0.59 . \Delta^{\text {atoms }} 0.52$ to 0.68 . Poor stoichiometry, uncertain $\mathrm{Q}^{\mathrm{xs}}$ content. Nepheline typically altered to cancrinite.

Chakrabarty et al. (2016) Agpaitic nepheline syenite $\Delta \mathrm{Al}-1.03$ to $+0.38, \Delta^{\text {atoms }}-0.13$ to +0.40 . Poor stoichiometry? Low Ca. Mol.\% NeKsQ ${ }^{\times s}$ match our calculations. Agpaitic nepheline syenite $\Delta \mathrm{Al}-1.03$ to $+0.38, \Delta^{\text {atoms }}-0.13$ to +0.4
Late-stage nepheline altered to sodalite, analcime, natrolite.

Source

Moreau et al. (1996)

Vulic et al. (2011)

Andersen et al. (2017)

\section{No nepheline end-member calcs}

Agpaitic and miaskitic nepheline syenites $\Delta \mathrm{Al}-0.23$ to $+0.16 ; \Delta^{\text {atoms }} 0.062$ to +0.78 . Shows alteration to cancrinite.

Probe analyses and single-crystal XRD structures, 10 samples from 5 localities; urtites, ijolites, pegs, Some associated with cancrinite. $\Delta \mathrm{Al}-0.27$ to $+0.045 ; \Delta^{\text {atoms }}-0.23$ to +0.16 . Mol.\% Ne 74.3 to 82.1 . Satellite peaks in all samples reflect incommensurate structures Miaskitic and agpaitic nepheline syenites from alkaline ring complex. EMP $1 \mu \mathrm{m}$ spot, $15 \mathrm{nA}$ current $\Delta \mathrm{Al}-0.35$ to $-0.054 ; \Delta^{\text {atoms }}-0.017$ to +0.85. Mol. Ne 75-77, An 0-0.5.

$\Delta \mathrm{Al}=$ atoms $\left(\mathrm{Al}+\mathrm{Fe}^{3+}\right)$ minus $(\mathrm{Na}+\mathrm{K}+2 \mathrm{Ca})$ per $32 \mathrm{O} ; \Delta^{\text {atoms }}=24$ minus (total all other atoms) per $32 \mathrm{O}$. D\&T and H\&G refer to references Dollase and Thomas $(1978)$ and Henderson and Gibb (1983), respectively.

the rock type other than the indications are that the highest $\mathrm{Q}^{\mathrm{xs}}$ values are shown by nepheline crystallising metastably as latecrystallising groundmass phases in basaltic differentiated sill rocks and that the higher Ks contents reflect the co-precipitation with alkali feldspars (cf. Gibb and Henderson, 1978; Henderson and Gibb, 1983, 1987; Wilkinson and Hensel, 1994). In some papers (e.g. Balassone et al., 2014; Valentin et al., 2020) it is clear that the $\mathrm{Ca}$ content and its associated cavity site value were not used together in the calculation of $A$-site vacancies, which in turn would lead to a Q' estimate that is too high. In another very recent paper (Vrublevskii et al., 2020), although the microprobe analyses look reliable, the calculated $\mathrm{Ne}, \mathrm{Ks}$, An and Q' values make no sense and, although some errors could be recognised, the calculation method followed could not be deduced.

However, in a more reliable paper, Blancher et al. (2010) described a detailed study of nepheline compositions from the differentiated sub-volcanic ring-complex of Messum, Namibia. Nephelines from the rock series theralite-diorite-monzonitesyenite-nephelinite and peralkaline syenite were assessed in terms of their compositional variations within the quaternary system $\mathrm{Ne}-\mathrm{Ks}-\mathrm{An}-\mathrm{Qz}$ (all defined on a 4 oxygen basis), on projections into the Barth 'composition plane of natural nepheline compositions', and their crystal-liquid fractionation trends projected onto the experimental $\mathrm{Ne}-\mathrm{Ks}-\mathrm{Qz}$ system at $1 \mathrm{kbar}$ water 
Table 4. Recalculation of nepheline atomic and molecular formulae for published analyses based on ideal nepheline stoichiometry.

\begin{tabular}{|c|c|c|c|c|c|c|c|c|c|c|c|c|c|c|c|c|c|c|c|}
\hline & $\begin{array}{c}\text { Barth } \\
\text { Ca } \times 5 \\
{[1]}\end{array}$ & & $\begin{array}{l}\text { This work, } \\
\text { Barth } \\
\text { Ca } \times 6 \\
{[2]}\end{array}$ & $\begin{array}{c}\text { This work } \\
\text { Ne70 } \\
{[3]}\end{array}$ & $\begin{array}{l}\text { D\&T } \\
\text { Syn } \\
{[4]}\end{array}$ & $\begin{array}{c}H \& G \\
\text { Crinan } \\
{[5]}\end{array}$ & $\begin{array}{c}\text { G\&H } \\
\text { Crinan } \\
{[6]}\end{array}$ & $\begin{array}{c}\text { W\&H } \\
\text { Theral } \\
{[7]}\end{array}$ & $\begin{array}{c}\text { Mellus } \\
\text { Pyrox } \\
{[8]}\end{array}$ & $\begin{array}{c}\mathrm{Bl} \text { et al. } \\
\text { Ther } \\
{[9]}\end{array}$ & $\begin{array}{c}\text { D\&T } \\
\text { Ne Sy } \\
{[10]}\end{array}$ & $\begin{array}{c}\text { H\&G } \\
\text { Ne Sy } \\
{[11]}\end{array}$ & $\begin{array}{c}\text { M\&P } \\
\text { Ne Sy } \\
{[12]}\end{array}$ & $\begin{array}{c}Z \text { et al. } \\
\text { Ne Sy } \\
{[13]}\end{array}$ & $\begin{array}{c}\text { Ander } \\
\text { Ne Sy } \\
{[14]}\end{array}$ & $\begin{array}{c}\text { Dawso et al. } \\
\text { ljolite } \\
\text { [15] }\end{array}$ & $\begin{array}{c}\text { D\&H } \\
\text { Neph } \\
{[16]}\end{array}$ & $\begin{array}{l}\text { Peters. } \\
\text { Neph } \\
{[17]}\end{array}$ & $\begin{array}{c}\text { Hamad et al. } \\
\text { Nephelinite } \\
\text { [18] }\end{array}$ \\
\hline \multicolumn{20}{|l|}{ Wt.\% } \\
\hline $\mathrm{SiO}_{2}$ & 42.85 & & & 52.48 & 53.44 & 49.8 & 50.3 & 51.82 & 44.34 & 42.34 & 44.88 & 43.8 & 45.10 & 42.79 & 45.65 & 42.1 & 40.3 & 41.80 & 42.56 \\
\hline $\mathrm{Al}_{2} \mathrm{O}_{3}$ & 33.36 & & & 29.69 & 29.19 & 30.9 & 30.5 & 29.81 & 32.31 & 34.38 & 34.00 & 34.1 & 33.30 & 32.62 & 31.48 & 28.6 & 28.0 & 31.54 & 32.27 \\
\hline $\mathrm{Fe}_{2} \mathrm{O}_{3}$ & 0.10 & & & & n.a. & 0.3 & n.a. & 0.40 & 0.69 & 0.36 & 0.45 & 0.12 & 0.20 & 2.13 & 1.06 & 5.2 & 8.02 & 2.62 & 1.07 \\
\hline MgO & & & & & & & n.a. & & & & & & & 0.04 & 0.02 & 0.33 & & n.a. & 0.12 \\
\hline $\mathrm{CaO}$ & 1.42 & & & 2.04 & n.a. & 0.6 & 0.18 & b.d.l. & 0.99 & 3.16 & 0.55 & 2.3 & 1.20 & 0.11 & b.d.l. & 0.06 & b.d.l. & 0.20 & 0.15 \\
\hline $\mathrm{Na}_{2} \mathrm{O}$ & 15.00 & & & 15.79 & 16.93 & 16.0 & 16.7 & 16.65 & 15.67 & 14.95 & 15.95 & 14.7 & 15.10 & 16.52 & 16.54 & 15.6 & 15.2 & 16.21 & 14.32 \\
\hline $\mathrm{K}_{2} \mathrm{O}$ & 5.81 & & & & 1.06 & 2.6 & 2.24 & 2.15 & 4.64 & 4.20 & 5.82 & 4.6 & 5.10 & 6.28 & 5.39 & 7.07 & 8.30 & 8.15 & 9.00 \\
\hline Total & 98.54 & & & 100.00 & 100.62 & 100.2 & 99.92 & 100.83 & 99.16 & 99.40 & 101.65 & 99.62 & 100.00 & 100.56 & 100.04 & 98.96 & 99.82 & 100.52 & 99.58 \\
\hline \multicolumn{20}{|c|}{ Atoms/32(0) } \\
\hline $\mathrm{Si}$ & 8.34 & & 8.333 & 9.600 & 9.740 & 9.245 & 9.340 & 9.514 & 8.543 & 8.141 & 8.441 & 8.359 & 8.566 & 8.252 & 8.713 & 8.377 & 8.101 & 8.184 & 8.332 \\
\hline Al & 7.67 & & 7.646 & 6.400 & 6.270 & 6.761 & 6.675 & 6.450 & 7.337 & 7.791 & 7.537 & 7.670 & 7.455 & 7.414 & 7.082 & 6.707 & 6.634 & 7.278 & 7.445 \\
\hline $\mathrm{Fe}^{3+}$ & & & 0.015 & & & 0.042 & & 0.055 & 0.100 & 0.054 & 0.064 & 0.017 & 0.029 & 0.309 & 0.152 & 0.779 & 1.213 & 0.386 & 0.158 \\
\hline $\mathrm{Mg}$ & & & & & & & & & & & & & & 0.011 & 0.006 & 0.098 & & & 0.035 \\
\hline $\mathrm{Ca}$ & 0.29 & & 0.296 & 0.400 & & 0.119 & 0.036 & & 0.204 & 0.651 & 0.111 & 0.470 & 0.244 & 0.023 & & 0.013 & & 0.042 & 0.031 \\
\hline $\mathrm{Na}$ & 5.67 & & 5.655 & 5.600 & 5.983 & 5.759 & 6.012 & 5.927 & 5.854 & 5.573 & 5.816 & 5.440 & 5.561 & 6.177 & 6.121 & 6.018 & 5.924 & 6.153 & 5.435 \\
\hline K & 1.44 & & 1.441 & & 0.246 & 0.616 & 0.531 & 0.504 & 1.140 & 1.030 & 1.396 & 1.120 & 1.236 & 1.545 & 1.312 & 1.795 & 2.129 & 2.036 & 2.248 \\
\hline$\Sigma$ cations & 23.41 & & 23.39 & 22.000 & 22.239 & 22.541 & 22.594 & 22.449 & 23.236 & 23.239 & 23.365 & 23.077 & 23.090 & 23.742 & 23.39 & 23.787 & 24.002 & 24.079 & 23.697 \\
\hline$\Delta$ (Al-cats) & -0.020 & & -0.028 & 0 & 0.041 & 0.189 & 0.060 & 0.075 & -0.082 & -0.061 & 0.166 & 0.187 & 0.198 & -0.044 & -0.200 & -0.353 & -0.206 & -0.61 & -0.14 \\
\hline $\begin{array}{l}\Delta\left(T_{\text {valency }}\right) \\
\text { Mol. \% }\end{array}$ & 0.035 & & -0.025 & 0 & 0.037 & 0.169 & 0.054 & 0.068 & -0.073 & -0.054 & 0.146 & 0.165 & 0.175 & -0.068 & -0.189 & -0.484 & -0.181 & -0.54 & -0.18 \\
\hline $\mathrm{Ne}$ & 70.8 & $\mathrm{Ne}$ & 70.51 & 70.0 & 74.78 & 71.46 & 75.16 & 73.39 & 71.92 & 68.99 & 71.91 & 67.78 & 69.15 & 73.35 & 74.61 & 65.50 & 58.89 & 72.09 & 65.91 (67.94) \\
\hline $\mathrm{Nf}$ & & $\mathrm{Nf}$ & 0.18 & & & 0.52 & & 0.69 & 1.25 & 0.67 & 0.80 & 0.22 & 0.36 & 3.86 & 1.90 & 9.73 & 15.16 & 4.82 & $2.03(1.98)$ \\
\hline Ks & 18.0 & Ks & 18.02 & & 3.08 & 7.70 & 6.63 & 6.29 & 14.26 & 12.88 & 17.46 & 14.00 & 15.45 & 18.90 & 16.26 & 19.99 & 26.61 & 25.44 & $27.22(27.25)$ \\
\hline $\mathrm{Kmg}$ & & $\mathrm{Kmg}$ & & & & & & & & & - & & & 0.41 & 0.14 & 2.45 & & & 0.88 \\
\hline $\mathrm{CaNe}$ & $6.0(\mathrm{An})$ & $\mathrm{CaNe}$ & 7.40 & 10.0 & & 2.98 & 0.90 & & 6.56 & 16.27 & 2.77 & 11.76 & 6.11 & 0.57 & & 0.32 & & 1.05 & $0.789(1.63)$ \\
\hline$Q^{\prime}$ & 2.7 & $Q^{\times s}$ & 3.89 & 20.0 & 22.13 & 17.33 & 17.32 & 19.62 & 6.01 & 1.18 & 7.07 & 6.25 & 8.94 & 2.91 & 7.08 & 2.02 & -0.7 & -3.41 & 3.18 (3.16) \\
\hline $\mathrm{Cn}$ & & $\mathrm{Cn}$ & -0.13 & & 0.19 & 0.93 & 0.28 & 0.36 & -0.39 & -0.29 & 0.78 & 0.88 & 0.93 & -0.21 & -0.94 & -1.66 & -1.0 & -2.86 & $-0.65(-0.72)$ \\
\hline \multirow[t]{3}{*}{$\square$ 'Holes' } & 2.5 & $\mathrm{Q}^{\mathrm{Si}}$ & 4.03 & 20.0 & 21.94 & 16.45 & 17.03 & 19.27 & 6.40 & 1.47 & 6.29 & 5.37 & 8.01 & 3.06 & 8.00 & 3.36 & 0.3 & -0.56 & 3.72 (3.72) \\
\hline & & $Q^{\text {cavity }}$ & 3.98 & 20.0 & 22.01 & 16.74 & 17.13 & 19.39 & 6.27 & 1.38 & 6.55 & 5.66 & 8.32 & 2.94 & 7.68 & 2.51 & -0.02 & -1.51 & 3.39 \\
\hline & & $\mathrm{Q}^{(\mathrm{Si}-\mathrm{Al})}$ & 4.20 & 20.0 & 21.69 & 15.26 & 16.66 & 18.80 & 6.91 & 1.85 & 5.25 & 4.20 & 6.77 & 3.34 & 9.25 & 5.59 & 1.59 & 3.25 & 4.58 \\
\hline $\mathrm{Ne}$ & & $\mathrm{Ne}$ & 76.34 & 77.78 & 74.78 & 74.20 & 75.83 & 74.08 & 78.31 & 83.26 & 74.78 & 77.05 & 74.03 & 77.97 & 76.62 & 77.37 & $72.42^{\star}$ & $72.83^{\star}$ & $69.1(69.1)$ \\
\hline Ks & & Ks & 19.46 & & 3.08 & 7.93 & 6.69 & 6.29 & 15.26 & 15.38 & 17.95 & 15.86 & 16.45 & 19.09 & 16.29 & 20.56 & $26.02^{\star}$ & $24.09^{\star}$ & $27.7(27.7)$ \\
\hline Q' & & $\mathrm{Q}^{\mathrm{xs}}$ & 4.20 & 22.22 & 22.14 & 17.87 & 17.47 & 19.62 & 6.44 & 1.41 & 7.27 & 7.08 & 9.52 & 2.94 & 7.09 & 2.07 & $1.56^{\star}$ & $3.08^{\star}$ & $3.2(3.2)$ \\
\hline \multicolumn{20}{|c|}{ Cavity site only } \\
\hline $\mathrm{Ne}$ & & $\mathrm{Ne}$ & 76.34 & 77.78 & 74.78 & 74.20 & 75.83 & 74.08 & 78.31 & 83.20 & 74.78 & 77.05 & 74.05 & 77.66 & 76.51 & 75.47 & $73.57^{\&}$ & $75.5^{\&}$ & $68.5(69.1)$ \\
\hline Ks & & Ks & 19.46 & & 3.08 & 7.93 & 6.69 & 6.29 & 15.26 & 15.38 & 17.95 & 15.86 & 15.87 & 19.42 & 16.41 & 22.51 & $26.43^{\&}$ & $24.5^{\&}$ & $28.3(28.6)$ \\
\hline \multicolumn{19}{|c|}{ Corrected for $\mathrm{Na}^{\mathrm{xs}}$} & $3.2(2.3)$ \\
\hline $\mathrm{Ne}$ & & & 76.0 & & 75.2 & 76.3 & 76.4 & 75.8 & 77.8 & 82.1 & 76.5 & 79.2 & 76.1 & 77.4 & 74.7 & 76.6 & 72.0 & 71.6 & 67.8 \\
\hline Ks & & & 19.5 & & 3.1 & 7.91 & 6.7 & 6.3 & 15.0 & 15.5 & 17.9 & 15.8 & 16.4 & 19.5 & 16.5 & 20.7 & 26.7 & 25.9 & 28.7 \\
\hline$Q^{\prime}$ & & & 4.5 & & 21.7 & 16.0 & 16.9 & 18.9 & 7.2 & 2.4 & 5.6 & 5.0 & 7.5 & 3.2 & 8.9 & 2.8 & 1.3 & 2.5 & 3.5 \\
\hline $\mathrm{Na}$-cancr. & & & 0.2 & & -0.4 & -1.5 & -0.5 & -0.6 & -0.4 & 1.0 & 1.4 & -1.5 & -1.6 & 0.3 & 1.6 & 1.0 & 1.7 & 5.0 & 1.1 \\
\hline
\end{tabular}

Abbreviations in top row: b.d.l. below detection limit; n.a. not analysed; Syn = synthetic; Crinan. = crinanite' Theral / Ther =theralite; Ne Sy= nepheline syenite; Nephel = nephelinite. ${ }^{*}$ Calculation for $Q^{(S i-A l)}$ values; ${ }^{\circledR}$-ve $Q$ recalculated Ne and Ks

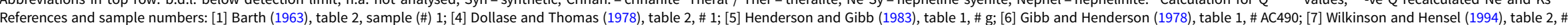

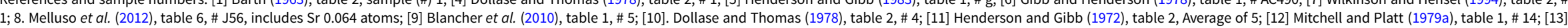

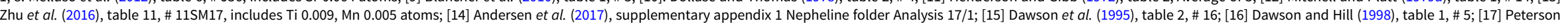
(1989), table 3, \# SH43; [18] Hamada et al. (2019), table 1; includes Ti 0.009, Cr 0.005 atoms. 
vapour pressure (Blancher et al., 2010). Thus the trend of decreasing $\mathrm{Ca}$ and increasing excess $\mathrm{Si}$ in nepheline with magmatic differentiation is well established for this well-characterised complex. This type of interpretation requires access to high quality analyses and rigorous nepheline end-member calculation. The data published by Blancher et al. (2010) includes 40 samples from representative rock types and all analyses fall within the recommended $\Delta \mathrm{Al}^{\mathrm{cc}}$ monitor ranging -0.25 to +0.25 . All 40 samples are included in the new database and 37 of these fall within the range $\Delta\left(T^{\text {charge }}\right)-0.25$ to +0.09 with the other three having $\Delta\left(\mathrm{T}^{\text {charge }}\right)$ values of $-0.33,-0.30$ and -0.27 . All 40 samples define a linear equation $y\left(\Delta\left(\mathrm{T}^{\text {charge }}\right)=0.82 x\left(\Delta \mathrm{Al}^{\mathrm{cc}}\right)-0.102\left(R^{2}=\right.\right.$ $0.703)$. In addition, note that for the 40 analyses the average $\Delta \mathrm{Al}^{\mathrm{cc}} / \Delta \mathrm{T}^{\text {charge }}$ ratio is $1.136 \pm 0.003$; this very tight ratio for such a range of nepheline compositions from the same magmatic complex is a good example of a high quality dataset. The mol.\% proportions calculated here for $\mathrm{Ne}$ and $\mathrm{Ks}$ are very close to those reported by Blancher et al. (2010) but the agreement for the $\mathrm{CaNe}$ and Q' values fluctuates, total $\mathrm{CaNe}+\mathrm{Q}$ generally being slightly larger than the Blancher et al. values. The fluctuation of CaNe values reflects whether the Blancher factor to convert atoms $\mathrm{Ca}$ per to mole fraction $\mathrm{CaNe}$ is greater or less than the standard equivalent value used by us (i.e. 6 for $32 \mathrm{O}$ atoms atomic proportions).

The parent rock types for nepheline analyses in columns 4-12 are all metaluminous $(\mathrm{Al}>\mathrm{Na}+\mathrm{K}+2 \mathrm{Ca})$ but have nephelines with positive or very small negative $\Delta \mathrm{Al}^{\mathrm{cc}}$ parameters and have $\Delta \mathrm{Al}^{\mathrm{cc}}$ / $\Delta \mathrm{T}^{\text {charge }}$ ratios within the narrow range 1.10 to 1.13 pointing to the charge distribution of the cavity cations matching that for the framework composition. The positive $\Delta \mathrm{Al}^{\mathrm{cc}}$ parameters are accompanied by small positive excess alumina parameters quantified here as \% Cn values ('normative' corundum values; Table 4, cf. Peterson, 1989). Analyses 14 to 17 are from peralkaline parent rocks and are distinguished by having significant negative $\Delta \mathrm{Al}^{\mathrm{cc}}$ parameters (range -0.15 to -0.61 ); the column 13 nepheline analysis is from a slightly peralkaline rock type and is intermediate with a negative $\Delta \mathrm{Al}^{\mathrm{cc}}$ parameter of -0.044 . These negative $\Delta \mathrm{Al}^{\mathrm{cc}}$ values point to the presence of excess $\mathrm{Na}\left(\mathrm{Na}^{\mathrm{xs}}\right)$ in nephelines from these rocks. It seems that the nepheline compositions in both the metaluminous rocks and the peralkaline silica-undersaturated syenites reflect the chemical affinity of the parental magmas and to the best of knowledge this has not been recognised before. Columns 15 and 16 show nepheline analyses from rocks occurring in the Oldoinyo-Lengai nephelinitenatrocarbonatite volcano, Tanzania (Dawson et al., 1995; Dawson and Hill, 1998); these microprobe analyses are characterised by high $\mathrm{Si}+\mathrm{Al}$ contents. In addition analysis 15 has a higher $\mathrm{Mg}$ content than most natural nephelines and this is equivalent to 2.45 mol.\% KsM nepheline end-member $\left(\mathrm{KMg}_{0.5} \mathrm{Si}_{1.5} \mathrm{O}_{4}\right)$. Microprobe $\mathrm{Mg}$ analyses are usually much smaller than this value $(<0.1$ wt.\%) and might usually be ignored nevertheless $\mathrm{Mg}$ and $\mathrm{Mn}$ should be included in the list of elements analysed by microprobe. The different Q' values for the nephelines from an Oldoinyo Lengai ijolite (Table 4, column 15) vary in the range 2.02 to 5.59 reflecting non-stoichiometry; however, the full nepheline dataset given in Dawson et al. (1995) shows a much wider variation with $\Delta \mathrm{Al}^{\mathrm{cc}}$ in the range 0.35 to +0.29 (20 of the 27 having negative values) with $\mathrm{Q}^{\mathrm{xs}}$ ranging from -0.84 to 7.5 (3 negative); $\mathrm{Q}^{\text {(Si-Al) }}$ values are generally higher varying from 1.0 to $6.7 \mathrm{~mol} \%$. The fact that the 20 peralkaline compositions all give positive $\mathrm{Q}^{(\mathrm{Si}-\mathrm{Al})}$ concentrations suggests that these estimates are more reliable than the $\mathrm{Q}^{\mathrm{xs}}$ values.
The analyses shown in columns 15 to 18 provide some extra insight about dealing with apparent nepheline non-stoichiometry. Peterson (1989) reported nepheline phenocrysts in nephelinites from Shombole (five rocks), Kenya, and Oldoinyo-Lengai (four rocks), Tanzania; all have negative Cn contents from -0.7 to $-3.7 \mathrm{~mol} \%$ and some had small negative $\mathrm{Q}^{\mathrm{xs}}$ values $(-0.6$ to -1.6 mol.\%) whereas others ranged from 0 to 4.7 (mean $1.3 \pm$ 1.0 mol.\%). Analysis 17 from Shombole volcano (Peterson, $1989)$ has high delta monitor values $(\sim-0.6)$ and high negative $\mathrm{Cn}$ and Q'. The high negative $\Delta \mathrm{Al}^{\mathrm{cc}}$ is due to $\mathrm{Na}+\mathrm{K}+\mathrm{Ca}$ totalling 8.23 , larger than the 8 cavity sites available in the nepheline structure. For nepheline analyses returning negative $Q$ values it might be preferable to define the excess Q' parameter as $\left(\mathrm{Si}^{\text {total }}-\mathrm{Al}\right) / 16$; clearly this estimate does not depend on $\mathrm{Na}, \mathrm{K}$ and $\mathrm{Ca}$ analyses. Thus, Table 4 includes calculated excess $\mathrm{Q}^{(\mathrm{Si}-\mathrm{Al})}$ for all the analyses; for most of them the agreement between the different Q' values is reasonably good. In particular, the $\mathrm{Q}^{(\mathrm{Si}-\mathrm{Al})}$ values for the nephelinite nephelines are now sensible, small and positive, rather than non-physical negative values. The final analysis in Table 4 (column 18, Hamada et al., 2019) shows a similar level of $\mathrm{Al}$ deficiency; note that the small $\mathrm{Ks} M$ component quoted for analysis 18 reflects the assignment of $M^{2+}$ in that analysis to a framework site rather than to a cavity cation site together with $\mathrm{Ca}$, which also accounts for the smaller $\mathrm{CaNe}(\mathrm{An})$ given here compared with the Hamada et al. analysis.

\section{The significance of the $\Delta A l^{c c} / \Delta T^{\text {charge }}$ ratio}

The full nepheline database of 310 analyses has been used to explore the significance of variation for the coupled $\Delta \mathrm{Al}^{\mathrm{CC}}$ and $\Delta \mathrm{T}^{\text {charge }}$ parameters and this variation is plotted in Fig. 1 using the same symbol for each separate analysis; most of the analyses plot on the same linear trend described by the linear fit $\Delta \mathrm{T}^{\text {charge }}=0.8928 \times \Delta \mathrm{Al}^{\mathrm{cc}}-0.0072\left(R^{2}=0.992\right)$. The slope of this line is equivalent to a mean $\Delta \mathrm{Al}^{\mathrm{cc}} / \Delta \mathrm{T}^{\text {charge }}$ ratio of 1.12 . The full dataset has some analyses with $\Delta \mathrm{Al}^{\mathrm{cc}} / \Delta \mathrm{T}^{\text {charge }}$ ratios differing widely from this mean and removal of $\sim 35$ analyses by only including those with ratios from 1.0 to 1.2 gives a trend with the equation $\Delta \mathrm{T}^{\text {charge }}=\left(0.8896 \times \Delta \mathrm{Al}^{\mathrm{cc}}\right)-0.0020\left(R^{2}=0.9987\right)$ and a mean $\Delta \mathrm{Al}^{\mathrm{cc}} / \Delta \mathrm{T}^{\text {charge }}$ ratio of $1.130 \pm 0.022$ that is very close to the average of $1.136 \pm 0.003$ for the 40 nepheline analyses reported by Blancher et al. (2010) for the Messum magmatic complex. It appears that this approach could provide another reliable method for assessing the quality of analyses however the fundamental significance of the value provided by this ratio must be assessed. For example, in a strict stoichiometric composition both individual delta parameters are zero and the ratio has no mathematical meaning. However a tiny variation from exact end-member stoichiometry (e.g. $\mathrm{Na}_{8} \mathrm{Al}_{8} \mathrm{Si}_{8.000001} \mathrm{O}_{32}$ ) provides a ratio that is close to a theoretical value of 1.42857 whereas $\mathrm{Na}_{8} \mathrm{Al}_{8} \mathrm{Si}_{8.0001} \mathrm{O}_{32}$ and $\mathrm{Na}_{8} \mathrm{Al}_{8} \mathrm{Si}_{8.01} \mathrm{O}_{32}$ are little different at 1.42856 and 1.142755 .

On the basis of the concept of the end-member stoichiometric nepheline having a stuffed tridymite unit cell with 32 oxygens, 16 $\mathrm{T}$ atoms and exactly 8 interframework cavity sites for $\mathrm{Na}$, it is clear that once one quadrivalent $\mathrm{Si}$ atom is replaced with one trivalent $\mathrm{Al}$ atom that must be accompanied by the entry of one $\mathrm{Na}$ atom into a cavity site. For all atomic substitutions that retain strict nepheline stoichiometry the crystal chemical 'die is cast' ("Alea iacta est" Julius Caesar, January 10, 49 BC). Thus it should be possible to define the delta parameter ratio in terms of the $\mathrm{Al}$ $\left(+\mathrm{Fe}^{3+}\right)$ and $\mathrm{Si}$ atoms alone (Kevin Knight pers. comm., July 4, 2020). 


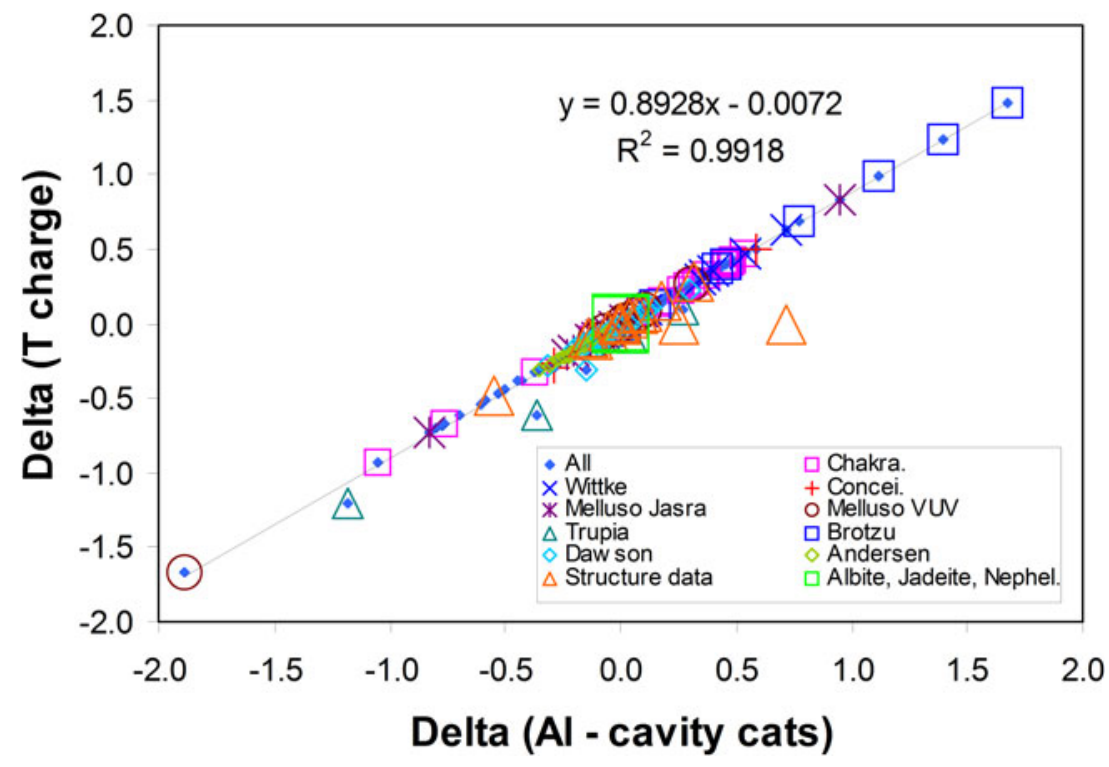

Fig. 1. Atomic formula units calculated to 32 oxygens are used to plot delta parameters $\Delta\left(\mathrm{Al}\right.$ - cavity cations) $\left[\Delta \mathrm{Al}^{\mathrm{cc}}\right]$ vs. $\Delta$ (T-site charge) $\left[\Delta \mathrm{T}^{\text {charge }}\right]$. The whole database of 310 analyses is plotted with the same symbol (small blue diamond). These points define a linear trend with the statistics of the fit displayed. A large proportion of points lie close to the line over the range \pm 0.5 for both $\Delta \mathrm{Al}^{\mathrm{cc}}$ and $\Delta \mathrm{T}^{\text {charge }}$ showing that these parameters are coupled closely for reliable analyses. Points that fall at delta values outside that range and falling further away from the linear trend are marked with symbols that are different for each literature source. Wittke = Wittke and Holm (1996); Melluso Jasra = Melluso et al. (2012); Trupia = Trupia and Nicholls (1996); Dawson = Dawson et al. (1995), Dawson and Hill (1998); Chakra. = Chakrabarty et al. (2016); Concei. = Conceição et al. (2009); Melluso VUV = Melluso et al. (1996); Brotzu = Brotzu et al. (1997); and Andersen = Andersen et al. (2017). Also shown are the compositions declared for samples that have been used to determine crystal structures by X-ray diffraction; points falling clear of the linear trend are considered to have unreliable compositions. See text for further detail.
The following stages show how such a relationship could be developed: let $\mathrm{N}, \mathrm{K}, \mathrm{C}, \mathrm{A}$ and $\mathrm{S}$ represent the numbers of atoms of $\mathrm{Na}, \mathrm{K}, \mathrm{Ca}, \mathrm{Al}$ (or $\mathrm{Al}+\mathrm{Fe}^{3+}$ ) and $\mathrm{Si}$, per $32 \mathrm{O}$ unit cell, respectively. Charge balance requires the constraint $\mathrm{N}+\mathrm{K}+2 \mathrm{C}+3 \mathrm{~A}$ $+4 \mathrm{~S}=64$. It has been shown above that $\Delta \mathrm{Al}^{\mathrm{cc}}=\mathrm{A}-2 \mathrm{C}-\mathrm{N}-$ $\mathrm{K}$, from the charge balance constraint $\Delta \mathrm{A}=-64+4 \mathrm{~S}+4 \mathrm{~A}$ and this definition is used here as it contains the same variables as $\Delta \mathrm{T}^{\text {charge }}$. Total charge $=4 \mathrm{~S}+3 \mathrm{~A}$; total charge per $\mathrm{T}$-site unit $=$ $(4 \mathrm{~S}+3 \mathrm{~A}) /(\mathrm{S}+\mathrm{A})$; ideal charge per $\mathrm{T}$-site unit $(4 \mathrm{~S}+3 \mathrm{~A}) / 16$. $\Delta \mathrm{T}^{\text {charge }}$ is defined above as the difference in total charge from the ideal charge and the total charge per T-site unit. Thus,

$$
\begin{aligned}
\Delta \mathrm{T}^{\text {charge }} & =16((4 \mathrm{~S}+3 \mathrm{~A}) / 16-(4 \mathrm{~S}+3 \mathrm{~A}) /(\mathrm{S}+\mathrm{A})) \\
& =(4 \mathrm{~S}+3 \mathrm{~A})(1-16 /(\mathrm{S}+\mathrm{A})) \\
& =((4 \mathrm{~S}+3 \mathrm{~A})((\mathrm{S}+\mathrm{A})-16)) /(\mathrm{S}+\mathrm{A})
\end{aligned}
$$

The next step is to calculate the ratio $(\Delta \mathrm{A} / \Delta \mathrm{T})$ (defined above as $\left.\Delta \mathrm{Al}^{\mathrm{cc}} / \Delta \mathrm{T}^{\text {charge }}\right)$ :

$(\Delta \mathrm{A} / \Delta \mathrm{T})=(-64+4 \mathrm{~S}+4 \mathrm{~A}) /(((4 \mathrm{~S}+3 \mathrm{~A})((\mathrm{S}+\mathrm{A})-16)) /(\mathrm{S}+\mathrm{A}))$

$(\Delta \mathrm{A} / \Delta \mathrm{T})=((-64+4 \mathrm{~S}+4 \mathrm{~A})(\mathrm{S}+\mathrm{A})) /((4 \mathrm{~S}+3 \mathrm{~A})(\mathrm{S}+\mathrm{A}-16))$

$$
\begin{array}{r}
(\Delta \mathrm{A} / \Delta \mathrm{T})=\left(-64 \mathrm{~S}-64 \mathrm{~A}+4 \mathrm{~S}^{2}+4 \mathrm{SA}+4 \mathrm{SA}+4 \mathrm{~A}^{2}\right) / \\
\left(4 \mathrm{~S}^{2}+4 \mathrm{SA}-64 \mathrm{~S}+3 \mathrm{SA}+3 \mathrm{~A}^{2}-48 \mathrm{~A}\right) \\
\begin{aligned}
\Delta \mathrm{A} / \Delta \mathrm{T}= & \left(-64 \mathrm{~S}-64 \mathrm{~A}+4 \mathrm{~S}^{2}+8 \mathrm{SA}+4 \mathrm{~A}^{2}\right) / \\
& \left(-64 \mathrm{~S}-48 \mathrm{~A}+4 \mathrm{~S}^{2}+7 \mathrm{SA}+3 \mathrm{~A}^{2}\right)
\end{aligned}
\end{array}
$$

and this leads to a key equation:

$$
\begin{aligned}
\left(\Delta \mathrm{Al}^{\mathrm{cc}} / \Delta \mathrm{T}^{\mathrm{charge}}\right)= & \left(64 \mathrm{~S}+64 \mathrm{~A}-4 \mathrm{~S}^{2}-8 \mathrm{SA}-4 \mathrm{~A}^{2}\right) / \\
& \left(64 \mathrm{~S}+48 \mathrm{~A}-4 \mathrm{~S}^{2}-7 \mathrm{SA}-3 \mathrm{~A}^{2}\right)
\end{aligned}
$$

This expression can be recast in terms of $S$ and the difference between $S$ and $A$. Let $S-A=\delta$, therefore $A=S-\delta$ ' Thus,

$$
\begin{aligned}
(\Delta \mathrm{A} / \Delta \mathrm{T})= & \left(64 \mathrm{~S}+64(\mathrm{~S}-\delta)-4 \mathrm{~S}^{2}-8 \mathrm{~S}(\mathrm{~S}-\delta)-4(\mathrm{~S}-\delta)^{2}\right) / \\
& \left(64 \mathrm{~S}+48(\mathrm{~S}-\delta)-4 \mathrm{~S}^{2}-7 \mathrm{~S}(\mathrm{~S}-\delta)-3(\mathrm{~S}-\delta)^{2}\right) \\
(\Delta \mathrm{A} / \Delta \mathrm{T})= & \left(128 \mathrm{~S}-16 \mathrm{~S}^{2}-4 \delta^{2}+16 \mathrm{~S} \delta-64 \delta\right) /\left(112 \mathrm{~S}-14 \mathrm{~S}^{2}\right. \\
& \left.-3 \delta^{2}+13 \mathrm{~S} \delta-48 \delta\right)
\end{aligned}
$$

leading to another key equation:

$$
\begin{aligned}
\Delta \mathrm{Al}^{\mathrm{cc}} / \Delta \mathrm{T}^{\text {charge }}= & \left(128 \mathrm{~S}-16 \mathrm{~S}^{2}+16 \mathrm{~S} \delta-64 \delta-4 \delta^{2}\right) /(112 \mathrm{~S} \\
& \left.-14 \mathrm{~S}^{2}+13 \mathrm{~S} \delta-48 \delta-3 \delta^{2}\right)
\end{aligned}
$$

For the relationships: $\delta$ is small, $\mathrm{S} \approx \mathrm{A}, \mathrm{S} \approx 8,128 \mathrm{~S} \approx 16 \mathrm{~S}^{2}$ and $112 \approx 14 \mathrm{~S}^{2}, \delta^{2}$ is small enough to be ignored and $\delta$ can be cancelled in the numerator and denominator: 1.1429

Thus, $\Delta \mathrm{Al}^{\mathrm{cc}} / \Delta \mathrm{T}^{\mathrm{charge}} \approx(128-64) /(104-48)=(64 / 56)=8 / 7=$

Even though the individual $\Delta \mathrm{Al}^{\mathrm{cc}}$ and $\Delta \mathrm{T}^{\text {charge }}$ parameters are each effectively zero, the strict nepheline stoichiometry still delivers a $\Delta \mathrm{Al}^{\mathrm{cc}} / \Delta \mathrm{T}^{\text {charge }}$ ratio of 1.1429 for end-member $\mathrm{NaAlSiO}_{4}$.

In the context of a strict stuffed-tridymite stoichiometry defining the nepheline unit cell, the integers 64 and 8 can be rationalised as referring to the ideal tridymite cell that has a total charge of 64 for 16 quadrivalent silicons (total $\mathrm{S}=16$ ) in the $32 \mathrm{O}$ unit cell. The unit cell has $8 \square^{\mathrm{Si}} \mathrm{Si}_{2} \mathrm{O}_{4}$ 'nepheline' molecules and thus $64 / 8=8$ per unit molecule. The integers 56 and 7 refer to the $\mathrm{Na}_{8} \mathrm{Al}_{8} \mathrm{Si}_{8} \mathrm{O}_{32}$ species $\left(8 \mathrm{NaAlSiO}_{4}\right.$ per unit cell) where the $\mathrm{T}$ site total is $56(8 \times 4+8 \times 3)$ and $56 / 8=7$. Following the same logic, an albite molecule expressed as having $32 \mathrm{O}$ cell would have the formula $\mathrm{Na}_{4} \mathrm{Al}_{4} \mathrm{Si}_{12} \mathrm{O}_{32}$ (total $\mathrm{T}$ charge $(12 \times 4+4 \times 3)=$ 60 ) and $60 / 8=7.5$; an anhydrous analcime would have the formula $\mathrm{Na}_{5.333} \mathrm{Al}_{5.333} \mathrm{Si}_{10.667} \mathrm{O}_{32}$ (total $\mathrm{T}$ charge $(10.667 \times 4+$ $5.333 \times 3)=58.667)$ and $58.667 / 8=7.3334$. These values lead to $\Delta \mathrm{Al}^{\mathrm{cc}} / \Delta \mathrm{T}^{\text {charge }}$ ratios of $8 / 7.5(1.0667)$ and $8 / 7.333$ (1.0909), 
respectively; see the values given earlier. The three end-members all have ideal stoichiometries and would have zero values for each delta parameter so the presence of excess silica in nephelines is not a sign of non-stoichiometry. The equivalent $\Delta \mathrm{Al}^{\mathrm{cc}} / \Delta \mathrm{T}^{\text {charge }}$ ratios for tridymite and the extreme alumina 'nepheline' endmember $\mathrm{Cn}$ molecule would be 1.000 and 1.3333. Departures from such ideal nepheline stoichiometry would allow delta ratios to deviate from these 'standard' values as would the presence of analytical errors. However, it is clear that the $\Delta \mathrm{Al}^{\mathrm{cc}} / \Delta \mathrm{T}^{\text {charge }}$ ratio is a direct monitor of how much a nepheline analysis deviates from the model, stuffed-tridymite unit cell and we will exploit this concept in dealing with the nepheline database. Indeed using the $\Delta \mathrm{Al}^{\mathrm{cc}} / \Delta \mathrm{T}^{\text {charge }}$ values for albite, analcime and leucite gives the determinative equation for calculating a $\mathrm{Si} / \mathrm{Al}$ ratio from the $\Delta \mathrm{Al}^{\mathrm{cc}} / \Delta \mathrm{T}^{\text {charge }}$ obtained from a nepheline analysis or from any average nepheline value as follows:

$$
\begin{aligned}
\mathrm{Si} / \mathrm{Al}= & 289.89\left(\Delta \mathrm{Al}^{\mathrm{cc}} / \Delta \mathrm{T}^{\text {charge }}\right)^{2}-66.84\left(\Delta \mathrm{Al}^{\mathrm{cc}} / \Delta \mathrm{T}^{\text {charge }}\right) \\
& +384.44\left(R^{2}=1\right)
\end{aligned}
$$

Deviation of nepheline compositions from ideal stoichiometry The $\Delta \mathrm{Al}^{\mathrm{cc}}$ vs. $\Delta \mathrm{T}^{\text {charge }}$ values for all the analyses in the new database (310 microprobe analyses) are plotted in Fig. 1. The individual analyses nephelines have $\Delta \mathrm{Al}^{\mathrm{lc}}$ and $\Delta \mathrm{T}^{\text {charge }}$ ranging from $\sim+1.7$ to -1.9 , far exceeding the values assumed to define acceptable analyses $( \pm 0.25)$. Of these analyses $\sim 80 \%$ fall within \pm 0.5 and $\sim 46 \%$ have negative ratios. Whether or not a new extended range for the $\Delta \mathrm{Al}^{\mathrm{cc}} / \Delta \mathrm{T}^{\text {charge }}$ ratio could be adopted to select reliable microprobe data as long as care was taken to avoid $\mathrm{Na}$ loss (i.e. low sample current, defocussed beam) must be assessed.

The end-member albite, anhydrous analcime and nepheline compositions calculated on an ideal nepheline stoichiometry all plot at the 0,0 point on Fig. 1 and the overall trend of points passes through this zero point; 55 of the full dataset of 310 analyses have delta values within a $\Delta \mathrm{Al}^{\mathrm{cc}}$ and $\Delta \mathrm{T}^{\text {charge }}$ range of \pm 0.05 . Positive delta values have excess alumina over cavity cations and $\mathrm{T}$ sites totalling $>16.000$ atoms per $32 \mathrm{O}$; negative delta values have excess cavity cations (mainly $\mathrm{Na}$ and $\mathrm{K}$ ) over alumina and $\mathrm{T}$ sites totalling $<16.000$ atoms per $32 \mathrm{O}$, in effect these nephelines are 'peralkaline' in bulk composition. Some analyses plot off this main trend or at surprisingly high or low points on the trend; all of such data points for each of those data sources are plotted over the main set of points with clearly different data symbols. Thus, the groundmass nepheline analyses from Trupia and Nicholls (1996) (blue open triangles in Fig. 4) all fall below the main trend suggesting that multiphase groundmass grains were analysed in that work. Four of the analyses from Brotzu et al. (1997) are deficient in cavity cations with $\Delta \mathrm{Al}^{\mathrm{cc}}$ values higher than +0.5 ; this might be due to $\mathrm{Na}$ loss in the electron beam. Analyses with excess alkali are more common $\left(\Delta \mathrm{Al}^{\text {cc }}\right.$ more negative than -0.5) as shown by some of the data points from Melluso et al. $(1996,2012)$ and Chakrabarty et al. (2016). Although most analyses appear to pass the tests for acceptability it should be remembered that calculating nepheline analyses on an ideal 32 oxygen basis alongside expecting $\mathrm{Si}+\mathrm{Al}+\mathrm{Fe}^{3+}$ to total close to 16.000 with fixed numbers of cavity cation sites (8) and total cation sites (24) and fixed end-member stoichiometry, all place constraints on the end data calculated. Indeed, the excess Q' proportions in particular are essentialy dependent on a fixed cavity site of 8 or a total cation sum of 24 . Small analytical errors for $\mathrm{Si}, \mathrm{Al}$ or $\mathrm{Na}$ would have the largest effect on the calculations and it seems that, in general, such errors cause the calculated points to move very slightly along or very close to the main linear trend with the main difference showing up for the excess Q' values. Because of this particular result, it is necessary to choose the best possible protocol for calculating end-member mineral proportions, in particular excess silica (Q'). Nevertheless, based on the fact that a very large proportion of the analyses plot in a concentrated band defining the linear trend of coupled delta values it seems that a range \pm 0.6 for both $\Delta \mathrm{Al}^{\mathrm{Ic}}$ and $\Delta \mathrm{Al}^{\text {charge }}$ could be used as a criterion to accept analyses.

The compositions for nephelines that have been used for X-ray single-crystal or powder structure determination (large orange open triangles) are also shown on Fig. 1. The synthetic samples are reported to have exact nepheline stoichiometry or to have very small delta parameters (Gregorkiewitz, 1984; Hippler and Böhm, 1989; Dollase and Thomas, 1978), whereas natural samples usually have very small delta parameters (Dollase, 1970; Dollase and Peacor, 1971; Hassan et al., 2003; Tait et al., 2003; Antao and Hassan, 2010). However, the sample from Kola (Tait et al., 2003) has excess cavity cations and delta parameters close to -0.5 but plots on the main trend (Fig. 1). The formulae given for samples studied by Foreman and Peacor (1970) and Simmons and Peacor (1972) appear to have been recalculated on the basis of $\mathrm{Si}+\mathrm{Al}=16.000$ and give zero $\Delta \mathrm{T}^{\text {charge }}$ values but non-zero $\Delta \mathrm{Al}^{\text {cc }}$ values of +0.25 and +0.72 respectively; such values would suggest a mismatch of charges between cavity cations and the framework. It is clear that the analytical data for these samples are not complete or are in error as it is essential that acceptable nepheline analyses should show closely coupled $\Delta \mathrm{Al}^{\mathrm{cc}}$ and $\Delta \mathrm{T}^{\text {charge }}$ values.

It is clear that the $\mathrm{Si} / \mathrm{Al}$ ratios of the analysed nephelines influences the values of the delta parameters though the tight stoichiometric controls imposed for the ideal nepheline cell also requires that both parameters are zero for analyses with $\mathrm{T}$ atoms totalling 16.000 irrespective of the $\mathrm{Si} / \mathrm{Al}$ ratio (cf. end members $\mathrm{NaAlSiO}_{4}, \mathrm{NaAlSi}_{2} \mathrm{O}_{6}$, and $\mathrm{NaAlSi}_{3} \mathrm{O}_{8}$ all have zero $\Delta \mathrm{Al}^{\mathrm{cc}}$ and $\Delta \mathrm{T}^{\text {charge }}$ values, see above). Thus Fig. 2 is used to show how the $\Delta \mathrm{Al}^{\mathrm{cc}} / \Delta \mathrm{T}^{\text {charge }}$ ratio varies as a function of $\mathrm{Si} / \mathrm{Al}$ ratio; the full database of analyses shows that the large majority define a linear trend showing only a small variation from $\Delta \mathrm{Al}^{\mathrm{cc}}$ / $\Delta \mathrm{T}^{\text {charge }} \approx 1.10$ over the $\mathrm{Si} / \mathrm{Al}$ range from 1.0 to 1.6. Approximately 30 analyses scatter around this trend, mainly with lower delta ratios. Some analyses are anomalously farremoved from the main trend and these are mainly due to analyses with close to 16.000 atom totals; for these analyses the $\Delta T^{\text {charge }}$ values tend to be smaller than for analyses with lower $\mathrm{Si}+\mathrm{Al}$ totals, and thus have less reliable delta ratios. Most of the 'scattered' analyses are from a few of the data sources and all of those are identified with different symbols in Fig. 2a. Figure $2 \mathrm{~b}$ shows the analyses which all fall within the $\Delta \mathrm{Al}^{\mathrm{cc}}$ / $\Delta \mathrm{T}^{\text {charge }}$ range from 1.0 to 1.25 and all of these are considered to be acceptable analyses. The main trend is defined by $\sim 250$ analyses of which $\sim 200$ are concentrated between $\Delta \mathrm{Al}^{\mathrm{cc}}$ / $\Delta \mathrm{T}^{\text {charge }}$ values of 1.144 and 1.125 over the $\mathrm{Si} / \mathrm{Al}$ range 1.0 to 1.15. The Messum igneous complex nephelines (Blancher et al., 2010) show the clear dependence of how the delta ratio decreases with increasing Si/Al. The points falling off this main trend tend to be from a few of the data sources and these are identified with different symbols in Fig. 2b. All of the analyses shown fall in the acceptable category though the ones showing the largest departures from ideal nepheline 

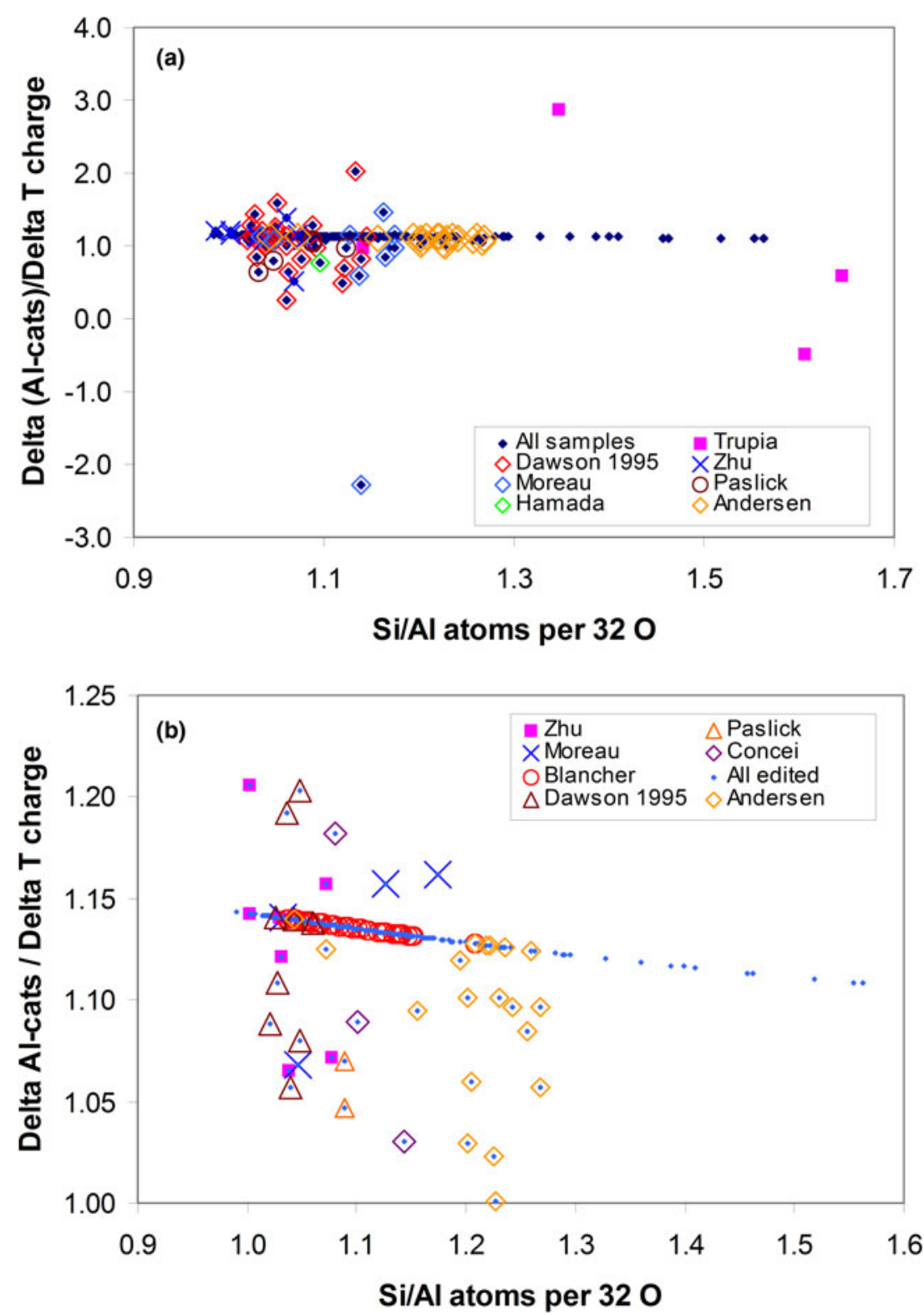

Fig. 2. Plot of atomic Si/Al vs $\Delta \mathrm{Al}^{\mathrm{cc}} / \Delta \mathrm{T}^{\text {charge }}$. (a) All of the database analyses are plotted with the same symbol and most analyses are seen to fall on a slightly falling delta ratio over the range $\mathrm{Si} / \mathrm{Al}$ from 1.0 to 1.55 . As in Fig. 1, points falling away from the main trend are identified with different symbols. One of the set of the Moreau analyses and three of Trupia's four analyses plot far from the main trend; all of those analyses and those having $\Delta \mathrm{Al}^{\mathrm{cc}} / \Delta \mathrm{T}^{\text {charge }}$ ratios between 0 and 1.0 and those which have the delta ratio $>1.25$ are considered to be unreliable (see text). (b) Si/Al vs. $\Delta \mathrm{Al}^{\mathrm{cc}} / \Delta \mathrm{T}^{\text {charge }}$ shows a large concentration of points define the trend of decreasing $\Delta \mathrm{Al}^{\mathrm{cc}} / \Delta \mathrm{T}^{\text {charge }}$ ratios with increasing $\mathrm{Si} / \mathrm{Al}$; that trend is well-displayed by the data for nephelines from the genetically related Messum magmatic complex (Blancher et al., 2010). Other samples labelled separately tend to be from peralkaline rock types. All of these points are believed to have reliable compositions. Andersen = Andersen et al. (2017); Blancher = Blancher (2010); Concei = Conceição et al. (2009); Dawson 1995 = Dawson et al. (1995); Hamada = Hamada et al. (2019); Moreau = Moreau et al. (1996); Paslick = Paslick et al. (1996); Trupia = Trupia and Nicholls (1996); Zhu = Zhu et al. (2016). stoichiometry are easily identified (Fig. 2b) from those defining the main linear trend.

\section{Significance of 'nepheline' analyses with high excess $\mathrm{Na}$ contents}

Although small amounts of an excess alumina component might occur in nepheline it is more probable that low $\mathrm{Na}$ microprobe analyses are the main explanation of positive $\Delta \mathrm{Al}^{\mathrm{cc}}$ values (Morgan and London, 2005). However, the occurrence of apparently reliable nepheline analyses showing significant cavity cation excesses over $\mathrm{Al}+\mathrm{Fe}^{3+}$ and the extension of the trend towards high negative delta values must be considered further. The presence of a small amount of an alteration phase containing low $\mathrm{Si}$ and $\mathrm{Al}$ and high alkalis (particularly $\mathrm{Na}$ ) would produce the small negative $\Delta \mathrm{Al}^{\mathrm{cc}}$ values shown by some analyses. Cancrinite-group minerals commonly occur as alteration phases of nepheline and sodalite groups of minerals in nepheline syenites as well as in hydrothermal veins associated with such rocks (e.g. Deer et al.,
2004, Moreau et al., 1996). The cancrinite-group mineral vishnevite is characterised by having lower $\mathrm{Si}$ and Al than nepheline with significantly higher $\mathrm{Na}$ contents in sodic varieties, and comparable $\mathrm{Na}$ contents and higher $\mathrm{Ca}$ occurs in cancrinite itself (Grundy and Hassan, 1982; Hassan and Grundy, 1984, 1991). Those authors have shown that $\mathrm{Na}$ and $\mathrm{H}_{2} \mathrm{O}$ are located within three-fold symmetry cancrinite 'cages' defined by top and bottom 6-rings of ordered $\mathrm{SiO}_{4}$ and $\mathrm{AlO}_{4}$ tetrahedra, whereas $\mathrm{Na}, \mathrm{Ca}$, $\mathrm{OH}^{-}, \mathrm{Cl}^{-}, \mathrm{CO}_{3}^{2-}$ (or $\mathrm{SO}_{4}^{2-}$ ) occur in large, continuous pseudohexagonal channels bounded by puckered 12-rings of tetrahedra; the two sites occupied by $\mathrm{Na}$ are structurally distinct. Note that end-member hydroxy-cancrinite $\left(\mathrm{Na}_{8}\left[\mathrm{Al}_{6} \mathrm{Si}_{6} \mathrm{O}_{24}\right](\mathrm{OH})_{2} \cdot 2 \mathrm{H}_{2} \mathrm{O}\right)$ has only hydroxyl as the anion in the large channel.

The overall effect of the compositional differences shown by Na-rich, low-Ca nephelines (e.g. Peterson, 1989) would be that $\sim 5 \%$ of a sodic cancrinite impurity phase, perhaps concentrated in cleavage cracks or occurring as inconspicuous fine alteration products, would produce the level of non-stoichiometry discussed above for the nephelines occurring in peralkaline rock types and 
some nephelinites (Table 4). However, the absence of any features associated with such an alteration process together with the database having many recent, apparently reliable, microprobe analyses of primary nepheline with coupled $\Delta \mathrm{Al}^{\mathrm{cc}}$ and $\Delta \mathrm{T}^{\text {charge }}$ parameters significantly more negative than -0.25 supports the possibility that such nepheline composition samples might show a small degree of solid solution of an alkali-rich molecule with cancrinitelike characteristics. Perhaps some embryo cage-like modifications might occur in the large hexagonal channels within the six-ring nepheline structure that might contain the excess alkalis in some nephelines? Indeed it is well known that many natural nephelines show features such as satellite diffraction peaks indicative of an incommensurate structure (Sahama, 1958; McConnell, 1962, 1981; Parker, 1972; Hayward et al., 2000; Hassan et al., 2003; Antao and Hassan, 2010). Friese et al. (2011) have re-determined the incommensurately modulated structure of one of the original nephelines studied by McConnell (1962) $\left(\mathrm{K}_{0.54} \mathrm{Na}_{3.24} \mathrm{Ca}_{0.03} \mathrm{Al}_{3.84} \mathrm{Si}_{4.16} \mathrm{O}_{16}\right)$ using superspace crystallography that was developed to study periodic structures that show long-range order but which lack translational symmetry. They found that all atoms are displacively modulated with amplitudes $<0.1 \AA$ and that $\mathrm{Na}$ fills the smaller (oval) channels, whereas $\mathrm{K}$, $\mathrm{Na}$ and $\mathrm{Ca}$ and vacancies occupy the larger (hexagonal) channels in a highly disordered manner. A large proportion of the framework oxygens show split-atom modulations and these effects are coupled to the occupational modulations of the cations (and vacancies) in the large channels. Perhaps this disordered local geometry could allow access of 'additional' small cations ( $\mathrm{Na}$ and $\mathrm{Ca}$ ) into the large nepheline channels to extend the effects of non-stoichiometry in natural nephelines.

The presence of a cancrinite-like molecule in nepheline would imply the presence of large anions and hydrous species associated with the extra $\mathrm{Na}$. Small amounts of structural ' $\mathrm{H}_{2} \mathrm{O}$ ' (up to $\sim 0.5 \mathrm{wt} . \%$ ) have been reported in nepheline for many years (Barth, 1963; Beran, 1974; Balassone and Beran, 1995). Beran and Rossman (1989) studied doubly polished slices of clear (non-turbid) single-crystal nephelines using controlled temperature infrared (IR) spectroscopy and reported the presence of 2 to 3 absorption features over the range $\sim 3500$ to $3630 \mathrm{~cm}^{-1}$. These were identified as fundamental $\mathrm{OH}$-stretching bands due to the presence of molecular water occupying the large, K-rich cavity sites; Belassone and Beran (1995) confirmed these IR results using nephelines from Monte Somma, Italy, and reported that the amount of water present was related to the proportion of vacancies present in the large B site in nepheline that contains all the $\mathrm{K}, \mathrm{Ca}$, vacancies and some of the Na. Yesinowski et al. (1988) reported similar IR features and in addition used MAS proton nuclear magnetic resonance (NMR) to show a sharp main central peak close to $0 \mathrm{kHz}$ with a small feature on the flank nearest to the $0 \mathrm{kHz}$ point; much less intense spinning side bands cover a frequency range of 50-60 kHz. Yesinowski et al. (1988) concluded that IR and ${ }^{1} \mathrm{H}-\mathrm{NMR}$ are consistent with two distinct water molecules in nepheline (cf. Beran, 1974), however, the NMR spectrum for analcime is distinctly different with a sharp central band close to $0 \mathrm{kHz}$ with two pairs of spinning side bands, of similar intensities to the central band flanking it, and other weaker ones which cover a frequency range of $\sim 100 \mathrm{kHz}$. Simakin et al. (2008) found similar IR results for clear nepheline single crystals with $0.20 \pm 0.05$ wt. $\% \mathrm{H}_{2} \mathrm{O}$ (SIMS) but then also used ${ }^{1} \mathrm{H}$ NMR pulse spectrometry at $200 \mathrm{MHz}$ that showed a central peak at $0 \mathrm{kHz}$ with a $\mathrm{PWHH}$ of $\sim 20 \mathrm{kHz}$ and broad shoulders on the flanks at $\sim+20$ and $-20 \mathrm{kHz}$. It is possible that the $\mathrm{OH}$-stretching bands in nepheline suggest that $\mathrm{Na}$ could be associated with both $\mathrm{OH}$ and water molecules; the $\mathrm{Na}$-cancrinite vishnevite $\left((\mathrm{Na}, \mathrm{Ca}, \mathrm{K})_{7-8}\left[\mathrm{Al}_{6} \mathrm{Si}_{6} \mathrm{O}_{24}\right]\left(\mathrm{SO}_{4} \mathrm{CO}_{3}, \mathrm{Cl}_{2}\right) \cdot 2 \mathrm{H}_{2} \mathrm{O}\right.$ has also been reported to show this structural environment for species in the large channel (Ventura et al., 2007). In addition, there might be some similarities for $\mathrm{H}_{2} \mathrm{O} / \mathrm{OH}$ speciation in nepheline to those in hydrous silicate glasses. For example, McMillan et al. (1983) studied clear hydrous albite glasses using Raman spectroscopy and reported the presence of a broad absorption band from $\sim 3400$ to $3600 \mathrm{~cm}^{-1}$ due to $\mathrm{O}-\mathrm{H}$ stretching and Stolper (1982), based on IR and NIR spectroscopy of volcanic and synthetic hydrous silicate glasses, concluded that hydroxyl was the main species up to $\sim 0.5 \mathrm{wt} \%$ water content, though above that amount molecular $\mathrm{H}_{2} \mathrm{O}$ became more important. Kohn et al. (1989) studied hydrous albite glasses by multinuclear NMR $\left({ }^{29} \mathrm{Si},{ }^{27} \mathrm{Al},{ }^{23} \mathrm{Na}\right.$ and $\left.{ }^{1} \mathrm{H}\right)$ and suggested that $\mathrm{Na}(\mathrm{OH})$ complexes may be present with the polar hydrogen of the molecular water - Na complex linked to the residual charge of a framework oxygen (their fig. 8). It seems that there might be some prima facie evidence for a small amount of a cancrinite-like $\mathrm{Na}-\mathrm{H}_{2} \mathrm{O}$ complex in nepheline.

The high-Na content of nephelines from peralkaline rocks could suggest the presence of $\sim 5 \%$ of a cancrinite-like phase. Nepheline phenocrysts from Shombole and Oldoinyo Lengai carbonatite volcanoes (E. Africa; Peterson et al., 1989) have high negative delta parameters; for example, analysis 17 (Table 4) has $\Delta \mathrm{Al}^{\mathrm{cc}}-0.61$ and $\Delta \mathrm{T}^{\text {charge }}-0.54$; the excess $\mathrm{Na}$ must be of the order of 0.5 to 0.6 atoms per $32 \mathrm{O}$, which is $\sim 10 \%$ of the total $\mathrm{Na}$ content. Assuming that this nepheline has the typical water content of $\sim 0.4$ wt.\% $\mathrm{H}_{2} \mathrm{O}$ this would be equivalent to $\sim 0.52$ molecules of $\mathrm{OH}$ per $32 \mathrm{O}$; the similarity of the $\mathrm{Na}$ and $\mathrm{OH}$ concentrations could be significant! In addition, Dawson et al. (1995) reported the presence of vishnevite in the Oldinyo-Lengai host rock BD875 of nepheline analysis 15 (Table 4), while Donaldson et al. (1987) gave analyses for coexisting phenocrysts of nepheline and vishnevite from an Oldinyo Lengai nephelinite (BD51; see their fig 1); that nepheline analysis has delta values close to zero ( 0.08 and 0.08 , respectively). If the coexisting nepheline and vishnevite in BD51 are in equilibrium it is reasonable to assume that the nepheline would be saturated in a vishnevite-like molecule. However, in a very recent investigation of Oldoinyo-Lengai samples, Berkesi et al. (2020) describe the compositions of melt inclusions found within nepheline phenocrysts that point to the coexistence of quenched, Na-rich immiscible, silicate- and carbonate-melt phases. It is suggested that these immiscible melt phases also coexisted with a separate peralkaline, fluorine-rich aqueous fluid phase. Note that an analysis of a parent nepheline grain that is contaminated by the presence of associated Na-rich silicate glass and/or trapped peralkaline fluid would have a composition similar to a cancrinite phase. Other researchers may wish to further consider this possibility.

The possible relationship between nepheline and coexisting cancrinite is considered in the next section of this paper assuming either a primary solid-solution origin or a late-magmatic/postmagmatic, hydrothermal alteration origin. Analyses used are for coexisting nepheline and cancrinite in undersaturated dyke-rock phonolites from the Marangudzi ring complex, Zimbabwe, a protocol will be developed for dealing with the compositions of cancrinite-bearing mixtures by calculating all compositions on the basis of a $32 \mathrm{O}$ nepheline unit cell. 


\section{Nepheline-cancrinite compositional and textural relationships in undersaturated igneous rocks}

The silica-undersaturated syenites from the Marangudzi ring complex contain nepheline as an essential mineral together with minor amounts of sodalite; both generally occur as late magmatic phases coexisting with interstitial to lath-shaped crystals of alkali feldspar in the syenitic rocks. Post-magmatic, alteration phases consist of patches of cancrinite, analcime and other zeolites in some rocks. The nature of nepheline in porphyritic phonolites differs by it occurring as phenocrysts together with cryptoperthitic alkali feldspars; some nepheline phenocrysts show blebs of a phase that was originally thought to have exsolved from the original nepheline phenocryst. However, other phonolites are distinctive by containing nepheline phenocrysts (usually up to $3 \mathrm{~mm}$ ) that show a welldeveloped prismatic cleavage with some grain orientations displaying a lamellar feature of alternating 'stripes' of clear nepheline and a pale brown Ca-bearing phase. Such compositional features of nephelines for two phonolites, samples A22 and A24, are described here; analyses were obtained by both wavelength dispersive (WD; Cambridge Instruments Microscan 9, Sheffield Geology Department; Geoscan 2 and Cameca Camebax, Manchester Geology Department) and by energy dispersive analysis (ED, Cambridge Instruments Geoscan fitted with a Link Systems 869-500 ED analyser, Manchester Geology).

Figure 3 shows an optical micrograph (black and white, plane polarised light) with the nepheline phenocryst displaying lamellar features with the $\sim 5-10 \mu \mathrm{m}$ pale-brown 'stripes' showing slightly darker greys. The dark spots mark beam-damaged regions analysed by WD methods using a $5 \mu \mathrm{m}$ beam on low-angle traverses across the lamellar stripes; adjacent double spots show where two sets of analyses were obtained. Table 5 has representative analyses showing these compositional features together with average analyses for the most sodic and calcic compositions. On the traverses, individual spot analyses varied from Ca-poor $(\sim 0.5$ wt. $\% \mathrm{CaO}$, Table 5 analyses 1 and 4$)$ to Ca-rich ( $\sim 6$ wt.\% CaO, Table 5 analysis 6); other analyses showed intermediate Ca contents reflecting mixtures of phases (Table 5, analysis 5). This is consistent with the electron beam straddling the interfaces between lamellae but also with the beam penetrating and sampling regions below the surface. It is clear that the two phases are nepheline and a Ca-rich cancrinite. Compositional traverses show very irregular compositions for adjacent spots reflecting these textural features but also probably affected by compositional heterogeneities within each lamella. On the basis of the traverse analyses, Fig. $3 \mathrm{a}$ and $\mathrm{b}$ show compositional data for individual spots and averages together with examples of cancrinite compositions taken from Deer et al. (1963 and 2004); note that the points shown for such cancrinites and analcime are recalculated to 32 oxygens so that the plotted compositions are directly comparable to those of the parent nepheline and its alteration products. The analytical spots for nepheline in all the traverses are shown in the $\mathrm{Ca} v s$. Na panel (Fig. 3b) with the average data for the parental (low-Ca) nepheline shown with a large symbol to signify error bars. The compositions of the 'mixed' phase analytical spots are shown trending in a scattered manner towards the compositions of a Ca-rich cancrinite composition. The Ca vs. Al panel (Fig. 3a) shows the point for the average low-Ca nepheline together with the individual points for the mixed phase and the highest Ca-points observed for the traverses; note that vishnevite variety cancrinites (DHZ4 and BD875) plot alongside some of the more calcic A22 lamella analyses but these vishnevites have low $\mathrm{K}$ contents (BD875 $=1.31$ wt.\%;

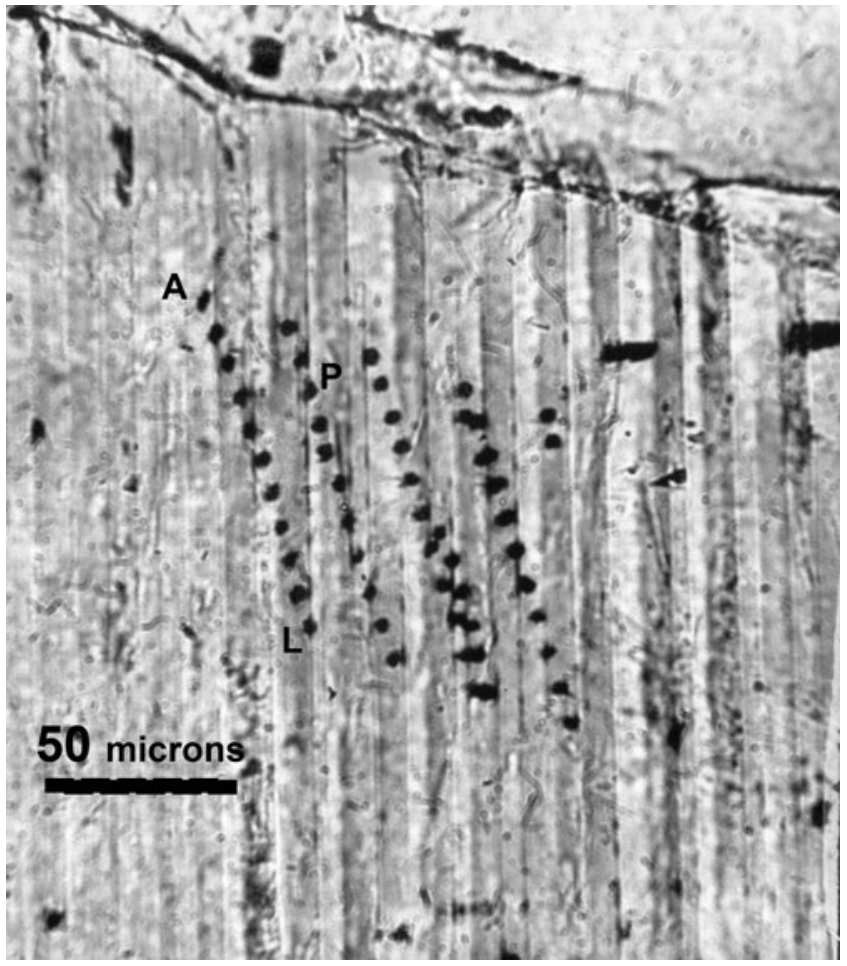

Fig. 3. Micrograph of a nepheline phenocryst from a phonolitic dyke (sample A22) from the Marangudzi ring complex, Zimbabwe. The striped structure shows the distribution of Ca-rich cancrinitic zones (darker grey) alternating with Ca-poor nepheline regions (pale grey). The darker spots ( $\sim 5 \mu \mathrm{m}$ diameter) mark the spots damaged by the electron microprobe beam; these are on traverses at low angles across the stripes and some double spots show adjacent spots from repeat traverses.

DHZ4 $=1.29$ wt. $\% \mathrm{~K}_{2} \mathrm{O}$ ) compared with those for the A22 cancrinite lamella compositions (average 6.2(1) wt.\%). The groundmass cancrinite compositions for Marangudzi phonolites G53 and A24 also have very low $\mathrm{K}$ contents below the detection limit $\left(<\sim 0.05\right.$ wt.\% $\left.\mathrm{K}_{2} \mathrm{O}\right)$; also see Henderson and Ezepue (1989). In Fig. $3 \mathrm{a}$ it is clear that two of the altered nepheline points have lower $\mathrm{Ca}$ and $\mathrm{Al}$ and trend towards the composition of analcime. The presence of a proportion of analcime in the alteration regions containing cancrinite would also explain some of the scatter of the Ca-bearing altered nephelines.

Figures $3 c$ and $d$ show the results of ED analyses of the nepheline phenocrysts in A22; all of these analyses were carried out manually to place the beam at the chosen positions. Defocussed electron beams ( 10 and $30 \mu \mathrm{m}$ diameter) were used to analyse grains without lamellae. Grains with alteration lamellae were analysed using $5 \mu \mathrm{m}$ spots and representative low-Ca spot analyses; the average low-Ca analysis are given in Table 5 (columns 2 and 3). The defocussed beam and normal beam average low-Ca nepheline analyses are shown in Figs $3 \mathrm{c}$ and $\mathrm{d}$ with the defocussed beam data having only a slightly more sodic composition indicating that the smaller beam did not result in significant diffusion of $\mathrm{Na}$ from the sample. The analyses of 'mixed region' and brown lamellae spots (e.g. Table 5, columns 5-9) are shown in both the $\mathrm{Al} v s . \mathrm{Na}$ and $\mathrm{Ca} v$ s. Na panels (Fig. $3 \mathrm{c}$ and d); in the former all the data plot in a simple band from the parent nepheline, through the 'mixed' samples to the cancrinite compositions with only small displacements towards an analcime composition. The Ca vs. Na plot (Fig. 3d) is more informative and displays a clear trend towards cancrinite for some altered nepheline spots 


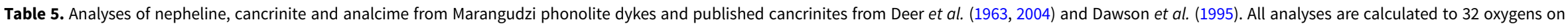
the stoichiometric nepheline basis.

\begin{tabular}{|c|c|c|c|c|c|c|c|c|c|c|c|c|c|c|c|c|c|c|c|}
\hline & [1] & [2] & [3] & [4] & $\begin{array}{l}{[5]} \\
\text { A22 }\end{array}$ & [6] & [7] & [8] & [9] & {$[10]$} & [11] & $\begin{array}{l}{[12]} \\
\mathrm{A} 24\end{array}$ & [13] & [14] & [15] & $\begin{array}{l}{[16]} \\
0\end{array}$ & $\begin{array}{c}{[17]} \\
\end{array}$ & $\begin{array}{c}{[18]} \\
\end{array}$ & [19] \\
\hline & $\begin{array}{l}\text { Pale lam. } \\
\text { Trav., } \\
\text { spot A } \\
\text { WD }\end{array}$ & $\begin{array}{l}\text { Pale } \\
\text { lam., } \\
5 \mu \mathrm{m} \\
\mathrm{ED}\end{array}$ & $\begin{array}{l}\text { Pale } \\
\text { lam. } \\
\text { Av. } 8 \\
\text { ED }\end{array}$ & $\begin{array}{c}\text { Pale } \\
\text { lam. } \\
\text { Av. } 19 \\
\text { WD Trav. }\end{array}$ & $\begin{array}{c}\text { Mixed sple. } \\
\text { Trav., } \\
\text { spot P } \\
\text { WD Trav. }\end{array}$ & $\begin{array}{l}\text { Bn lam. } \\
\text { Trav, } \\
\text { spot L } \\
\text { WD }\end{array}$ & $\begin{array}{c}\text { Bn lam. } \\
5 \mu \mathrm{m} \\
\text { ED }\end{array}$ & $\begin{array}{l}\text { Bn lam. } \\
\text { Av. } 5 \\
\text { ED }\end{array}$ & $\begin{array}{l}\text { Bn lam. } \\
\text { High Ca } \\
\text { ED }\end{array}$ & $\begin{array}{c}\text { Pale lam. } \\
\text { Av. } 7 \\
\text { ED }\end{array}$ & $\begin{array}{c}\text { Pale lam. } \\
\text { Av. } 7 \\
\text { WD }\end{array}$ & $\begin{array}{l}\text { Bn lam. } \\
\text { Av. } 6 \\
\text { ED }\end{array}$ & $\begin{array}{l}\text { Gdm. } \\
\text { WD }\end{array}$ & $\begin{array}{l}\text { Analc } \\
\text { WD }\end{array}$ & $\begin{array}{l}\text { Gdm., bn } \\
\text { alt. patch } \\
\text { f.g. } \\
\text { ED }\end{array}$ & Cancr. & Cancr. & Vish. & $\begin{array}{l}\text { Neph? } \\
\text { gdmas. }\end{array}$ \\
\hline \multicolumn{20}{|l|}{ Wt.\% } \\
\hline $\mathrm{SiO}_{2}$ & 42.77 & 44.3 & 44.7 & 43.32 & 41.71 & 39.6 & 39.3 & 35.5 & 35.5 & 43.08 & 43.6 & 38.9 & 35.3 & 53.9 & 30.5 & 34.0 & 30.9 & 34.7 & 42.76 \\
\hline $\mathrm{Al}_{2} \mathrm{O}_{3}$ & 33.75 & 32.7 & 32.8 & 34.06 & 32.60 & 31.1 & 29.2 & 29.2 & 29.6 & 33.60 & 34.2 & 30.9 & 28.6 & 23.8 & 16.4 & 29.1 & 26.0 & 28.5 & 30.01 \\
\hline $\mathrm{Fe}_{2} \mathrm{O}_{3}$ & 0.35 & 0.43 & 0.43 & 0.36 & 0.35 & 0.60 & 0.35 & 0.34 & b.d.l. & 0.38 & 0.40 & 0.45 & b.d.l. & b.d.l. & 1.14 & b.d.l. & n.a. & 0.67 & 2.31 \\
\hline $\mathrm{CaO}$ & 0.43 & 0.36 & 0.24 & 0.45 & 2.83 & 6.22 & 5.27 & 13.3 & 14.1 & 0.45 & 0.54 & 7.73 & 8.76 & n.a. & 23.9 & 4.80 & 13.54 & 4.57 & 8.83 \\
\hline $\mathrm{Na}_{2} \mathrm{O}$ & 16.16 & 16.1 & 16.2 & 16.04 & 15.7 & 14.8 & 14.4 & 13.1 & 13.4 & 15.98 & 16.7 & 14.5 & 15.8 & 13.7 & 6.4 & 18.69 & 9.94 & 19.7 & 12.01 \\
\hline $\mathrm{K}_{2} \mathrm{O}$ & 6.27 & 5.60 & 5.8 & 6.02 & 6.00 & 5.55 & 5.27 & 5.3 & 5.67 & 6.59 & 6.40 & 6.11 & 0.04 & 0.13 & 2.8 & 0.64 & 5.11 & 1.31 & 3.35 \\
\hline $\mathrm{s}$ & & & $<0.08$ & & $<0.08$ & & & & $<0.08$ & & & $<0.1$ & $<0.05$ & $<0.05$ & 0.88 & & & & \\
\hline $\mathrm{Cl}$ & & & $<0.09$ & & $<0.09$ & & & & $<0.09$ & & & $<0.1$ & $<0.05$ & $<0.05$ & 0.21 & & & & \\
\hline Total & 99.62 & 99.5 & 100.1 & 100.47 & 99.19 & 97.6 & 96.0 & 96.7 & 98.3 & 100.09 & 101.8 & 98.6 & 89.14 & 91.57 & 82.3 & 87.22 & 85.46 & 89.45 & 99.33 \\
\hline \multicolumn{20}{|c|}{ Atoms/32(0) } \\
\hline $\mathrm{Si}$ & 8.513 & 8.515 & 8.545 & 8.287 & 8.163 & 7.958 & 7.999 & 7.409 & 7.335 & 8.296 & 8.258 & 7.816 & 7.693 & 10.569 & & 7.599 & 7.506 & 7.638 & 8.314 \\
\hline $\mathrm{Al}$ & 7.691 & 7.404 & 7.389 & 7.678 & 7.519 & 7.377 & 7.464 & 7.365 & 7.202 & 7.626 & 7.637 & 7.320 & 7.513 & 5.496 & & 7.672 & 6.882 & 7.394 & 6.877 \\
\hline $\mathrm{Fe}^{3+}$ & 0.051 & 0.062 & 0.063 & 0.052 & 0.053 & 0.053 & 0.092 & 0.054 & & 0.055 & 0.058 & 0.068 & & & & & & 0.111 & 0.189 \\
\hline $\mathrm{Ca}$ & 0.089 & 0.074 & 0.033 & 0.092 & 0.593 & 1.340 & 1.148 & 2.979 & 3.122 & 0.093 & 0.109 & 1.666 & 2.011 & & & 1.15 & 3.528 & 1.078 & 1.871 \\
\hline $\mathrm{Na}$ & 6.058 & 6.018 & 5.987 & 5.966 & 5.938 & 5.777 & 5.674 & 5.288 & 5.350 & 5.967 & 6.118 & 5.671 & 6.658 & 5.203 & & 8.104 & 4.687 & 8.408 & 4.527 \\
\hline K & 1.548 & 1.374 & 1.404 & 1.514 & 1.506 & 1.423 & 1.367 & 1.401 & 1.461 & 1.619 & 1.547 & 1.569 & 0.011 & 0.033 & & 0.183 & 1.585 & 0.368 & 0.831 \\
\hline ¿cations & 23.683 & 23.447 & 23.421 & 23.588 & 23.774 & 23.928 & 23.744 & 24.500 & 24.470 & 23.656 & 23.727 & 24.110 & 23.886 & 21.301 & & 24.708 & 24.189 & 24.997 & 22.758 \\
\hline$\Delta$ (Al-cats) & -0.041 & -0.073 & -0.006 & 0.066 & -1.06 & -2.45 & -2.16 & -5.23 & -5.85 & -0.092 & -0.188 & -3.18 & -3.18 & 0.261 & & -2.91 & -6.45 & -3.43 & -1.89 \\
\hline $\begin{array}{l}\Delta\left(T_{\text {valency }}\right) \\
\text { Mol.\% }\end{array}$ & -0.036 & -0.114 & -0.013 & 0.058 & -0.93 & -2.16 & -2.70 & -4.10 & -4.10 & -0.081 & -0.165 & -2.80 & -2.79 & 0.238 & & -2.55 & -5.68 & -3.00 & -1.67 \\
\hline $\mathrm{Ne}$ & 75.7 & 74.4 & 74.1 & 74.6 & 74.2 & 72.2 & 70.9 & 68.1 & 66.9 & 74.6 & 76.3 & 70.9 & 83.2 & 65.4 & & 101.3 & 58.6 & 103.7 & 56.6 \\
\hline Ks & 19.3 & 17.7 & 17.6 & 18.9 & 18.9 & 17.8 & 17.1 & 17.6 & 18.3 & 20.2 & 19.3 & 19.6 & 0.14 & 0.41 & & 2.28 & 19.8 & 4.60 & 10.4 \\
\hline $\mathrm{CaNe}$ & 2.23 & 1.85 & 0.83 & 2.31 & 14.8 & 35.5 & 28.7 & 74.8 & 78.1 & 2.33 & 2.72 & 41.7 & 50.28 & 0 & & 28.8 & 88.2 & 27.0 & 46.8 \\
\hline$Q^{\mathrm{xs}}$ & 2.72 & 5.75 & 6.78 & 4.20 & -7.91 & -23.5 & -16.7 & -58.1 & -66.6 & 2.84 & 1.47 & -32.1 & -33.65 & 34.6 & & -32.3 & -66.6 & -36.6 & -13.8 \\
\hline $\mathrm{Cn}$ & -0.19 & -0.34 & -0.03 & 0.31 & -4.97 & -11.5 & -8.4 & -24.5 & -27.4 & -0.93 & -0.88 & -14.9 & -14.9 & 1.2 & & -13.7 & -30.2 & -16.1 & -8.9 \\
\hline$Q^{S i}$ & 2.91 & 6.10 & 6.80 & 3.27 & -2.94 & -12.0 & -8.37 & -32.8 & -35.8 & 3.27 & 2.35 & -17.2 & -18.7 & 33.5 & & -18.7 & -36.4 & -20.6 & -4.93 \\
\hline $\mathrm{Q}^{(\mathrm{Si}-\mathrm{Al})}$ & 3.26 & 6.6 & 6.9 & 3.48 & 3.69 & 3.30 & 2.97 & -0.07 & 0.83 & 3.84 & 3.52 & 2.68 & 2.18 & 31.7 & & -0.46 & +3.9 & +0.83 & $\begin{array}{r}+6.88 \\
\end{array}$ \\
\hline \multicolumn{20}{|l|}{ Mol.\% } \\
\hline $\mathrm{Ne}$ & 77.4 & 76.6 & 75.5 & 76.3 & 76.7 & 77.4 & 77.9 & 79.5 & 77.7 & 76.4 & 78.6 & 76.1 & 98.2 & 65.0 & & 97.8 & 71.2 & 95.0 & 76.6 \\
\hline Ks & 19.8 & 17.5 & 17.7 & 19.4 & 19.5 & 19.1 & 18.8 & 20.5 & 21.3 & 20.7 & 19.9 & 21.0 & 0.2 & 0.4 & & 2.2 & 24.1 & 4.2 & 14.1 \\
\hline$Q^{\prime}$ & 2.8 & 5.9 & 6.8 & 4.3 & $3.8^{\&}$ & $3.5^{\&}$ & $3.3^{\&}$ & $\&$ & $1.0^{\&}$ & 2.91 & 1.51 & $2.9^{8}$ & $2.6^{8}$ & 34.6 & & $\&$ & $4.7^{8}$ & $0.8^{\&}$ & $9.3^{8}$ \\
\hline
\end{tabular}

Abbreviations: \& Ne-Ks-Q' proportions calculated using the Q'(Si-Al) value rather than $\mathrm{Q}^{\times s} ;$ Trav. = traverse; av. = average; sple = sample; Bn= brown; lam. = lamella or lamellae; Gdm. = groundmass; f.g. = fine grained; Analc. = analcime; Cancr. = cancrinite; Vish. = vishnevite (cancrinite group); others defined in text.

Reference and sample number of analyses: [1 to 12] this paper; [13-14] Henderson and Ezepue (1989); [15] A24 Groundmass, this paper; [16] Cancrinite DHZ4, Deer et al. (1963), table 39 analysis 4; [17] Cancrinite DHZ16, Deer et al. (2004), table 19, Vishnevite BD 875, Dawson et al. (1995), table 3, analysis 8; [19] Melloso et al. (1996), analysis of groundmass phase identified as nepheline, also contains SrO 0.29 wt.\%, 0.033 atoms added to $\mathrm{Ca}$, Fe reported as $\mathrm{FeO}$ but recalculated as $\mathrm{Fe}_{2} \mathrm{O}_{3}$. 
and a less populated trend towards analcime. Other spots reflect the presence of both cancrinite and analcime in the alteration domains. Fewer analyses are available for the lamellae in nepheline phenocrysts in phonolite A24 (Table 5, columns 10-12) but the general trends are identical to those described above for A22 (Fig. 3e and $\mathrm{f}$ ).

The totals found for both the WD and ED analyses have not been considered so far. In general the totals are close to $100 \%$ for the pale spot analyses and generally range from $~ 96$ to $98 \%$ for the brown lamellae, which seems somewhat high for a cancrinite that should contain other components such as $\mathrm{OH}, \mathrm{Cl}, \mathrm{CO}_{3}$, and $\mathrm{S}$ or $\mathrm{SO}_{4}$ complexed mainly with $\mathrm{Ca}$. Totals for groundmass cancrinites are generally much lower at $\sim 90 \%$. However, in some sets of analyses for sample $\mathrm{A} 22, \mathrm{Cl}$ was looked for (detection limit $\sim 0.5 \%$ ) because of the possible presence of sodalite, though it was never detected. In WD analyses of sample A24 both S and $\mathrm{Cl}$ were analysed but were rarely detected above a two sigma error of 0.06 wt.\%; indeed the highest $\mathrm{S}$ detected for a groundmass cancrinite in A24 was 0.18 wt.\%. It is concluded here that $\mathrm{Cl}$ and S/ $\mathrm{SO}_{4}$ are not significant components, suggesting that only hydroxyand carbonate-anion complexes might be present with the former being the more likely occurring as a hydroxy-cancrinite molecule (see above). Edgar (1964) showed experimentally that carbonateand hydroxy-cancrinite were stable up to $\sim 800^{\circ} \mathrm{C}$ at $1.3 \mathrm{~kb} P_{\mathrm{H}_{2} \mathrm{O}}$.

The primary nepheline, 32 oxygen recalculation spreadsheet was used to calculate 'working atomic formulae' for the associated cancrinite and analcime. Inspection of the output points to the scale of departure from stoichiometric nepheline compositions (Table 5). Thus the parental low-Ca nepheline compositions for sample A22 (Table 5 columns 1-4) have nepheline monitor parameters $\Delta \mathrm{Al}^{\mathrm{cc}}$ and $\Delta \mathrm{T}^{\mathrm{charge}}$ well within the range \pm 0.25 with similar values. These analyses show only small $C n$ values (usually small ve) and similar values for $\mathrm{Q}^{\mathrm{xs}}$ and $\mathrm{Q}^{\mathrm{Si}}$ excess quartz values consistent with these compositions conforming to nepheline stoichiometry. The analyses showing intermediate $\mathrm{Ca}$ contents (i.e. 'mixed' spots, Table 5 column 5) have higher delta values, higher negative $C n$ values and negative $Q^{\prime}$ values with $\mathrm{Q}^{\mathrm{xs}}$ and $\mathrm{Q}^{\mathrm{Si}}$ showing large differences. With increasing $\mathrm{Ca}$ content in the cancrinites (Table 5, columns 6-9) these trends continue with the analysis having 14 wt.\% $\mathrm{CaO}$ showing the highest departures from nepheline stoichiometry (see column 9, Table 5). The same relationships are clear in the A24 sample (Table 5, columns 9-12) and the published cancrinite compositions (Table 5, columns 16-18) and in these cases the key parameters clearly reflect the characteristic compositional features of Ca-rich cancrinites and higher $\mathrm{Na}$ and $\mathrm{Ca}$ components could reflect their association with large anions (e.g. $\mathrm{OH}^{-}, \mathrm{Cl}^{-}, \mathrm{CO}_{3}^{2-}, \mathrm{SO}_{4}^{2-}$ ). The negative $\Delta \mathrm{Al}^{\mathrm{cc}}$ values are anomalously high in the cancrinite-bearing compositions because much of that $\mathrm{Ca}$ must be complexed with large anions and should not be considered a part of the basic nepheline framework (see below). In the last section of this paper the negative compositional parameters, which reflect the presence of 'extra' alkalis and $\mathrm{Ca}$ in the cancrinite cages, will be dealt with by correcting the data for the natural cancrinites for their content of 'cage cations' associated with carbonate, sulfate and chloride. However, at this stage the simpler definition of an excess Q' component by using the relationship $\mathrm{Q}^{\prime}=(\mathrm{Si}-\mathrm{Al}) \times 100 / 16$ (Table 2, equation $\left.8 ; \mathrm{Q}^{(\mathrm{Si}-\mathrm{Al})}\right)$ is used; this simply models the composition of the framework of a cancrinite-bearing phase and is independent of the cavity cation and 'cage-cation' content. Table 5 shows that the calculated $\mathrm{Ne}-\mathrm{Ks}-\mathrm{Q}$ ' compositions of the cancrinitebearing samples now give formulae for nepheline-like framework compositions with reasonable excess Q' values ranging from 0 to $6 \%$ (average $3 \pm 2 \%$ ) although the $\mathrm{Ne}$ contents must be anomalously high because all of the $\mathrm{Na}$ content was used to calculate the Ne component.

Although other minerals with similar chemical features to cancrinite (e.g. nosean, sodalite) would show similar trends, the fact that nepheline and cancrinite have more similar structural and chemical properties based on the lack of $\mathrm{Cl}$ and $\mathrm{S}$ and on the presence of 6-ring tetrahedral units puts the present interpretation onto a stronger footing. It is also suggested that the groundmass calcic nepheline ( 8.83 wt.\% $\mathrm{CaO}$ ) analysis reported by Melluso et al. (1996) undoubtedly contains cancrinite as a significant alteration product and data for that analysis are also given in Table 5 (column 19).

It is concluded that the alteration of the primary nepheline, present both as phenocrysts and groundmass phases, took place during the deuteric cooling of the Marangudzi rocks by Ca-rich hydrothermal fluids gaining access to the nepheline phenocrysts via the welldefined prismatic cleavages. The alteration lamellae seem to have been able to maintain fairly well-defined margins following the original cleavage boundaries. The groundmass cancrinite is characterised by a relatively low K-content presumably reflecting the low $\mathrm{K}$ activity of the fluids, though the altered nepheline regions in the phenocryst generally retained a significant amount of the primary $\mathrm{K}$ content. Indeed, the brown cancrinite lamellae have very similar $\mathrm{Ne} / \mathrm{Ks}$ ratios irrespective of the Ca contents (Table 5, columns 4 to 9). The formation of the analcime phase probably occurred at relatively low temperatures, perhaps $\sim 500^{\circ} \mathrm{C}$ (Henderson et al., 2014) following the earlier formation of cancrinite just below the solidus temperature (Edgar, 1964).

Returning to the Ca-rich nepheline analyses discussed above, it is necessary to assess which have compositions consistent with a primary origin. The Marangudzi altered sample with $2.8 \% \mathrm{CaO}$ (Table 5, analysis 5) has $\Delta \mathrm{Al}^{\mathrm{cc}}$ and $\Delta \mathrm{T}^{\text {charge }}$ values of 1.06 and 0.93 clearly indicating deviation from nepheline stoichiometry; the negative excess $\mathrm{Q}^{\mathrm{xS}}$ and $\mathrm{Q}^{\mathrm{Si}}$ values also indicate this feature. By contrast, nepheline compositions from other rock types and complexes, for example, analysis 9 (Table 4, Blancher et al., $2010)$ has $3.16 \% \mathrm{CaO}$ with much lower $\Delta$ values $(\sim-0.06)$ and significant $\mathrm{Q}^{\mathrm{xs}}$ contents; these features are consistent with a primary nepheline origin. It is also possible that the Ca-rich nepheline analysis with $2.76 \mathrm{wt}$ \% $\mathrm{CaO}$ (Rossi et al., 1989) is a reliable 'primary' nepheline with $\Delta \mathrm{Al}^{\mathrm{cc}}$ and $\Delta \mathrm{T}^{\text {charge }}$ values of -0.10 and -0.09 and calculated $\mathrm{CaNe}$ and $\mathrm{Q}^{\mathrm{xs}}$ of 14.1 and $2.3 \mathrm{~mol} \%$, respectively. The Marangudzi cancrinite-bearing nephelines all have $\mathrm{SiO}_{2}$ and $\mathrm{Al}_{2} \mathrm{O}_{3}$ concentrations $\sim 2 \%$ smaller than primary nephelines and it is that feature, together with the presence of excess $\mathrm{Ca}$ complexed with large anions rather than entering as a $\mathrm{CaNe}$ molecule, that leads to the higher negative $\Delta \mathrm{Al}^{\mathrm{Cc}}$ and lower excess $\mathrm{Q}^{\mathrm{xs}}$ content. The key discriminator of the presence/absence of alteration to cancrinite is placed at a $\Delta \mathrm{Al}^{\mathrm{cc}}$ of $\sim-0.3$. On that basis, it seems that nepheline analyses from Oldoinyo Lengai and Shombole (Peterson, 1989; see his table 2, columns 15 and 17) might have included a very small proportion (perhaps up to 5\%) of a cancrinite alteration product, presumably occurring as an unobtrusive, very fine grained material and located in cleavages and/or cracks. If there is no sign of such alteration, the possibility that primary nepheline could contain a very small amount of solid solution with a cancrinite-group mineral must then be considered. That possibility would benefit from a limited experimental investigation with a hydrated $\left(\mathrm{NaAlSiO}_{4}\right.$ gel or glass starting material plus $\sim 10 \% \mathrm{CaCO}_{3}$ ) enclosed in 

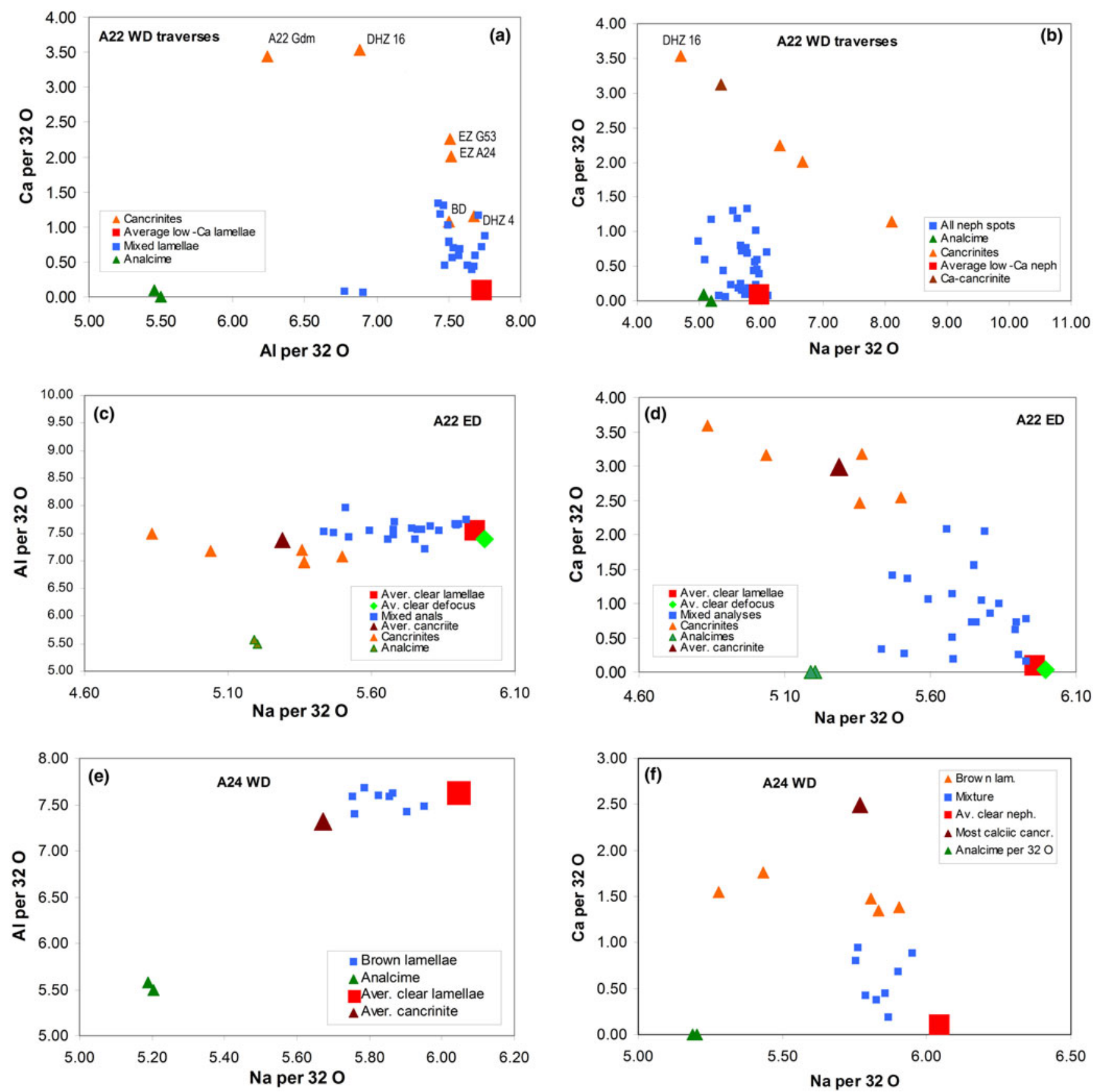

Fig. 4. Electron microprobe analyses of altered nepheline phenocrysts and groundmass cancrinites from Marangudzi phonolites A22, A24 and G53. In all six panels the large red square symbols mark the analyses of the primary low-Ca nephelines; some of these analyses were obtained with defocussed beam spots (diameter up to $30 \mu \mathrm{m}$ ) and these compositions are little different from those obtained from $5 \mu \mathrm{m}$ spots. Also shown are the compositions of Marangudzi groundmass grains of Ca-rich cancrinite; typical Na-rich vishnevites BD875 (Dawson et al., 1995) and DHZ 4 (Deer et al., 1963); Ca-rich cancrinite DHZ 16 (Deer et al., 2004 ); and Marangudzi groundmass analcime. (a) Ca vs. Al data for WD traverses in A22; (b) Ca vs. Na data for WD traverses in A22; (c) Al vs. Na ED analyses for A22; (d) Ca vs. Na analyses for A22; (e) Al vs. Na WD analyses for A24; $(f)$ Ca vs. Na WD analyses for A24.

sealed capsules and run in a cold-seal pressure vessel at $\sim 100 \mathrm{MPa}$ pressure and $700^{\circ} \mathrm{C}$; unfortunately this is beyond the hands-on experimental capability of the present author.

\section{Criteria for assessing reliability of nepheline analyses}

It has been shown that departures from ideal nepheline stoichiometry lead to differences between the calculated excess values
$\mathrm{Q}^{\mathrm{xs}}, \mathrm{Q}^{\mathrm{Si}}, \mathrm{Q}^{\mathrm{cav}}$ and $\mathrm{Q}^{(\mathrm{Si}-\mathrm{Al})}$. Section $\mathrm{S} .4$ in the accompanying Supplementary material assesses formulation of delta parameters of the form $\Delta\left(\mathrm{Q}^{1}-\mathrm{Q}^{2}\right)$. For ideal nepheline stoichiometry $\Delta\left(\mathrm{Q}^{\mathrm{xs}}-\mathrm{Q}^{\mathrm{Si}}\right)$, $\Delta\left(\mathrm{Q}^{\mathrm{xs}}-\mathrm{Q}^{(\mathrm{Si}-\mathrm{Al})}\right), \Delta\left(\mathrm{Q}^{\mathrm{xs}}-\mathrm{Q}^{\mathrm{cav}}\right)$, and $\Delta\left(\mathrm{Q}^{\mathrm{Si}}-\mathrm{Q}^{\mathrm{cav}}\right)$ all reduce to the relationship $\Delta \mathrm{Q}^{\prime}=16-\mathrm{Si}^{\text {total }}-\left(\mathrm{Al}+\mathrm{Fe}^{3+}\right)$ however analytical errors and the departure from ideal stoichiometry give each Q' a different value. In this final section the use of the parameter $\Delta\left(\mathrm{Q}^{\mathrm{xs}}-\mathrm{Q}^{\mathrm{Si}}\right)=16-\mathrm{Na}-\mathrm{K}-2 \mathrm{Ca}-\mathrm{Si}^{\text {total }}$ is advocated as another 
way of discriminating the acceptability of nepheline analyses together with $\Delta \mathrm{Al}^{\mathrm{cc}}$ and $\Delta \mathrm{T}^{\text {charge }}$.

Figure $5 \mathrm{a}$ shows a plot of the $\Delta \mathrm{Al}^{\mathrm{cc}}$ term against the chosen $\Delta\left(\mathrm{Q}^{\mathrm{xS}}-\mathrm{Q}^{\mathrm{Si}}\right)$ parameter, with the latter values calculated from the differences between mol.\% values for $\mathrm{Q}^{\mathrm{xs}}$ and $\mathrm{Q}^{\mathrm{Si}}$ multiplied by $24 / 100$ to make the atom numbers directly comparable to those used to calculate $\Delta \mathrm{Al}^{\mathrm{cc}}$. Although acceptable nepheline analyses are generally required to fall within the $\Delta \mathrm{Al}^{\mathrm{cc}} \pm 0.25$ range, the database of published nepheline analyses shows that $\sim 85 \%$ of these points define a very tight band over the range \pm 0.8 for both $\Delta \mathrm{Al}^{\mathrm{cc}}$ and $\Delta\left(\mathrm{Q}^{\mathrm{xs}}-\mathrm{Q}^{\mathrm{si}}\right)$ (i.e. the database of 310 nepheline analyses shows a linear fit with slope 1.12 and $R^{2}=0.99$ ); $\sim 35$ of this database had $\Delta \mathrm{Al}^{\mathrm{cc}}$ significantly outside the \pm 0.25 range. The $15 \%$ of analyses separate from the main trend include three from Brotzu et al. (1997) which appear to have anomalously low alkali contents, and one analysis each from Trupia and Nicholls (1996), Melluso et al. (1996) and Chakrabarty et al. (2016). In addition, four analyses from Mitchell and Platt (1979b) define the group of points plotting just above the main nepheline band. It is clear that although ideal nepheline stoichiometry defines zero values for both of these parameters, cooperative compositional variations in both of the delta values occur within the nepheline structure and it seems that use of this approach allows the range of acceptable analyses to be substantially widened, perhaps to \pm 0.8 . Note that the new low-Ca analyses of nepheline phenocrysts from Marangudzi phonolite dykes fall within the acceptable nepheline trend.

The trend of analyses towards more negative delta values shows the compositions of cancrinites and nepheline that might have been partially altered to cancrinite (see above); all of these analyses were recalculated on a 32 oxygen basis together with the nepheline analyses discussed here. This trend reflects the presence of alkalis and $\mathrm{Ca}$ complexed with large anions $\left(\mathrm{Cl}^{-}, \mathrm{OH}^{-}\right.$, $\mathrm{CO}_{3}^{2-}$ and $\mathrm{SO}_{4}^{2-}$ ) present in either the cancrinite cages or in the large channel. Also shown in Fig. 5a are analyses for sodalite, nosean and haüyne (Deer et al., 2004) that fall on the same 32 oxygen trend as cancrinite reflecting the same compositional differences, note though that these feldspathoids all have totally different aluminosilicate frameworks from those of nepheline and cancrinite. For each of cancrinite, haüyne and nosean the more negative delta values are shown by the samples with the highest $\mathrm{Ca} / \mathrm{Na}$ ratios. Analcime compositions are not shown in Fig. 5 but would all plot very close to the zero delta point.

Figures $5 b$ and $c$ explore the variations in composition in more detail especially for the nepheline analyses showing cancrinitetype compositional affinities. In Fig. $5 \mathrm{~b}$ the extension of the $\Delta$ ( $\mathrm{Al}$ - cations) trend to high negative values reflects the presence of $\mathrm{Na}$ and $\mathrm{Ca}$ large anion complexes in the cancrinites. For the analyses with very low excess $\mathrm{Si}$ values, which are subject to large errors, this means that such samples could have either high +ve or -ve $\left(\mathrm{Q}^{\mathrm{xs}}-\mathrm{Q}^{\mathrm{Si}}\right) / \mathrm{Q}^{\mathrm{xs}}$ values both of which suggest the presence of a cancrinite component in the analyses. Fig. $5 \mathrm{c}$ shows that the excess $\mathrm{Na}$ and $\mathrm{Ca}$ estimates in the $\mathrm{DHZ}$ cancrinite analyses have been corrected for on the basis of their analysed carbonate, sulfate and $\mathrm{Cl}$ contents; anions were complexed with $\mathrm{Ca}$ first and then with $\mathrm{Na}$ if required. The remaining cavity cation species were then used to calculate the $\Delta \mathrm{Al}^{c \mathrm{c}}$ parameter. For the Marangudzi high- $\mathrm{Ca}$ nepheline analyses the $\mathrm{CaO}$ content has been decreased to $0.8 \mathrm{wt} . \% \mathrm{CaO}$, which is assumed to be the probable primary $\mathrm{CaO}$ content of the parent phenocrystic nepheline. On the basis of this diagram all analyses falling away from the main nepheline trend are thought to have a cancrinite component either as a nepheline alteration product or possibly due to the presence of a small amount of cancrinite in solid solution in the nepheline.

It is clear the presence of excess alkalis has a significant effect on the excess silica content calculated if equations equating all of the cavity cations (mainly $\mathrm{Na}$ ) are assumed to be present within the stoichiometric $\mathrm{Ne}$, Ks and $\mathrm{CaNe}$ end-members (ie. Table 2, equations 1,3-7 and 9-13). It was suggested above that the excess silica should be calculated using $\mathrm{Q}^{(\mathrm{Si}-\mathrm{Al})}=\mathrm{Si}^{\text {total }}-\left(\mathrm{Al}+\mathrm{Fe}^{3+}\right) \times$ 100/16 (cf equation 8, Table 2) to avoid this problem. For cancrinite analyses it was shown above that analyses of the large anions associated with the excess $\mathrm{Na}$ (or $\mathrm{Ca}$ ) could be used to complex the excess alkalis present in the channels. Another approach that might be feasible with alkali-rich nepheline analyses is to calculate the $\mathrm{Na}$ atoms within the $\mathrm{Ne}$ component using a modified equation 9 which is based on the occupancy of the cavity cation site including the vacancies associated with the $\mathrm{CaNe}$ and excess $\mathrm{Q}^{(\mathrm{Si}-\mathrm{Al})}$ contents, thus:

$$
\mathrm{Na} \text { in } \mathrm{Ne}=8-\mathrm{K}-2 \mathrm{Ca}-\left(\mathrm{Si}^{\text {tot }}-\mathrm{Al}\right) / 2
$$

The excess Na content (denoted $\mathrm{Na}^{\mathrm{xs}}$ ) is then calculated by subtracting the corrected $\mathrm{Na}\left(\mathrm{Na}^{\text {corr }}\right)$ from the original $\mathrm{Na}^{\text {total }}$. On the basis of the protcol used above for dealing with the $\mathrm{Na}^{\mathrm{xs}}$ in cancrinite analyses, this excess $\mathrm{Na}^{+}$should be neutralised within any large anion $-\mathrm{Na}^{\mathrm{xs}}$ molecular complexes present in the large, $\mathrm{B}$-site nepheline cavities, and it is necessary to renormalise the atomic proportions of the remaining components to 32 oxygens. The recalculated atomic proportions for all the atomic species, including the new $\mathrm{Na}^{\text {corr }}$ value, would then be used to define new values for $\mathrm{Ne}, \mathrm{Ks}$ and $\mathrm{CaNe}$ proportions for the remaining calculations. In addition, the $\mathrm{Na}^{\mathrm{xs}}$ value could be used to estimate the proportion of a cancrinite-like component in the nepheline cell, i.e., $\mathrm{Na}^{\mathrm{xs}} \times 100 / 2.666$ (cf. the hydroxycancrinite 32 oxygen end-member $\left.\mathrm{Na}_{8}\left[\mathrm{Al}_{8} \mathrm{Si}_{8} \mathrm{O}_{32}\right] \cdot(\mathrm{NaOH})_{2.666} \cdot n \mathrm{H}_{2} \mathrm{O}\right)$. In the section above on 'Assessment of igneous rock nepheline component calculations' the analyses with an excess of $\mathrm{Al}+\mathrm{Fe}^{3+}$ over $\mathrm{Na}+\mathrm{K}+$ $2 \mathrm{Ca}$ were considered to have a corundum component (denoted $\mathrm{Cn}$ ); such compositions would have a negative $\mathrm{Na}^{\mathrm{xs}}$ value following the calculations described above and with $\mathrm{Na}^{\text {corr }}$ the same amount larger than the original $\mathrm{Na}$ atoms per $32 \mathrm{O}$. Although some of the low $\mathrm{Na}$ nepheline analyses might reflect loss of $\mathrm{Na}$ during microprobe analyses, the possible presence of an excess $\mathrm{Al}$ nepheline molecule should still be considered. The same calculation can be used to deal with very Ca-poor cancrinites though those with major $\mathrm{Ca}$ contents might generally be expected to have little or no Ca within the nepheline framework, and effectively all the Ca would be in the large channels complexed with large anions; in that case none of the $\mathrm{Ca}$ can be assumed to occur in cavity cations sites and the calculation is not reliable!

The full 310 analysis nepheline database has been used to calculate the corrected nepheline end-member parameters and Fig. 6 shows the new plots for the $\Delta \mathrm{Al}^{\text {cc }} v s . \Delta^{\text {charge }}$ and $\mathrm{Si} / \mathrm{Al} v s . \Delta \mathrm{Al}^{\mathrm{cc}} /$ $\Delta T^{\text {charge }}$ relationships. It is clear that the trends displayed show none of the scatter of analyses shown by the original data ( $c f$. Fig. 6a with Fig. 1; and Fig. 6b with Fig. 2a); in addition, the $\Delta \mathrm{Al}^{\mathrm{cc}}$ and $\Delta^{\text {charge }}$ values are much smaller than before and the separate values calculated for $\mathrm{Q}^{(\mathrm{Si}-\mathrm{Al})}, \mathrm{Q}^{\mathrm{xs}}, \mathrm{Q}^{\mathrm{Si}}, \mathrm{Q}^{\mathrm{cav}}$ for each analysis are now very similar. The slope of the linear plot in Fig. $6 \mathrm{a}$ is equivalent to a mean $\Delta \mathrm{Al}^{\mathrm{cc}} / \Delta \mathrm{T}^{\text {charge }}$ ratio of 1.134 , which is a typical value for a silica-rich natural nepheline. All of these 

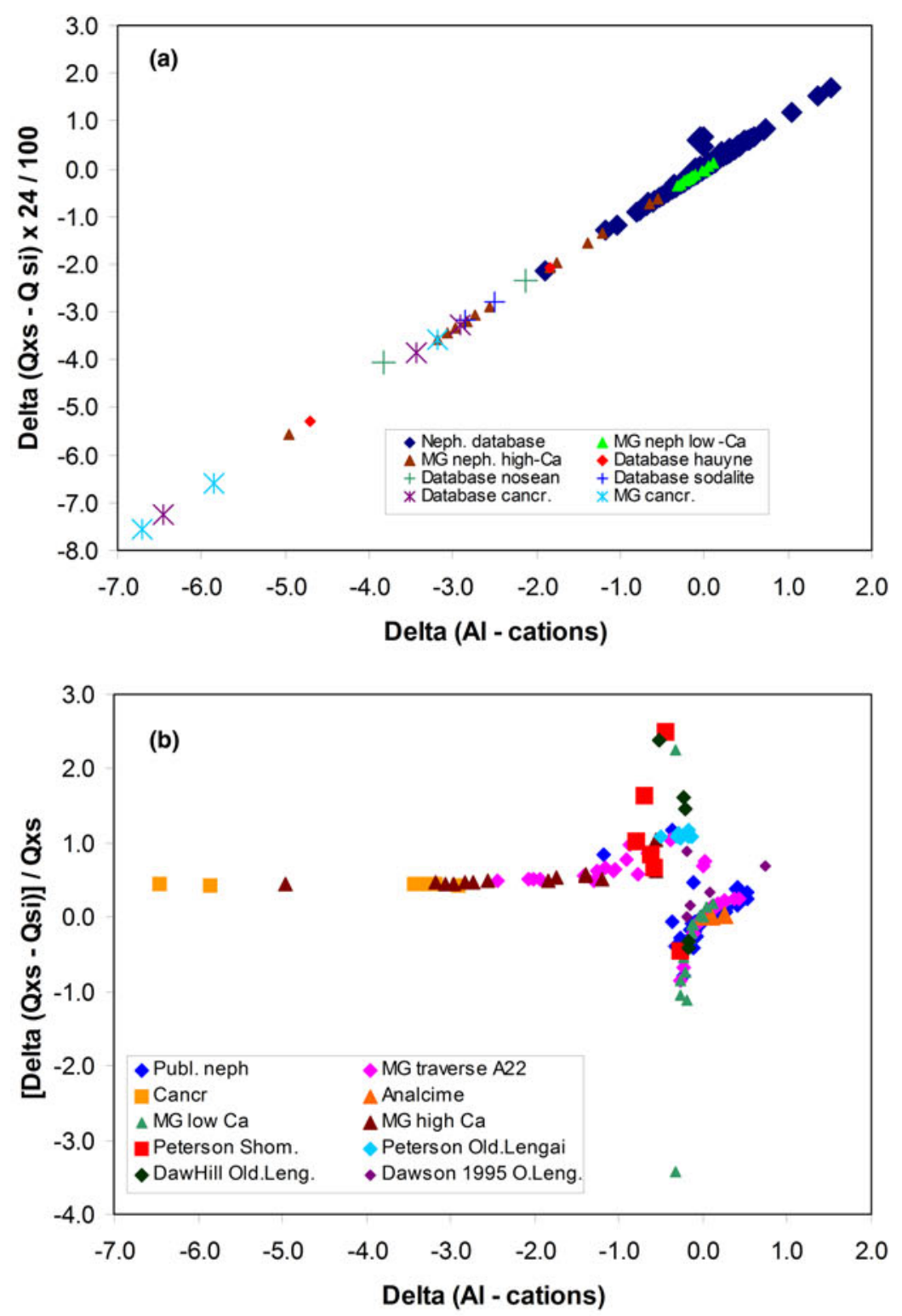

Fig. 5. Data for nepheline database analyses (this paper), Marangudzi altered nephelines (this paper), published (database) cancrinite and sodalite-group mineral compositions. (a) $\Delta\left(Q^{\mathrm{Xs}}-\mathrm{Q}^{\mathrm{Si}}\right) \times 24 / 100$ vs. $\Delta A I^{c c}$. The altered Marangudzi nepheline is plotted with the same symbol (small blue diamonds). Also plotted are the analyses from 'primary' Ca-poor Marangudzi nephelines (MG green triangles) and those altered to more Ca-rich compositions (MG brown triangles). The nepheline trend is extended to higher negative values by analyses that are believed to have a cancrinite component; also shown are points for Marangudzi cancrinites (MG) published (database) $\mathrm{Na}$ and Ca-cancrinite compositions, and also database sodalite, haüyne and nosean. (b) $\Delta\left(\mathrm{Q}^{\mathrm{xs}}-\mathrm{Q}^{\mathrm{si}}\right) / \mathrm{Q}^{\mathrm{xs}} v s$. $\Delta \mathrm{Al}^{\mathrm{cc}}$. Same samples as shown in (a). (c) $\Delta\left(\mathrm{Q}^{\mathrm{xs}}-\mathrm{Q}^{\mathrm{si}}\right) / \mathrm{Q}^{\mathrm{xs}}$ vs. $\Delta \mathrm{Al}^{\mathrm{cc}}$. Same as above data with the published (database) cancrinite compositions having cavity cation contents reduced by the amounts that would be neutralised by the analysed amounts of $\mathrm{OH}, \mathrm{CO}_{3}$ of $\mathrm{SO}_{4}$, and with subtracting all $\mathrm{Ca}$ contents greater than $0.8 \mathrm{wt} . \% \mathrm{CaO}$ from the Ca-rich, altered nepheline compositions. See text for explanation. Peterson = Peterson (1989); Dawhill = Dawson and Hill (1998); Dawson = Dawson (1995); Brotzu = Brotzu et al. (1997); PetDaw s. = Peterson (1989), Dawson and Hill (1998) and Dawson (1995).

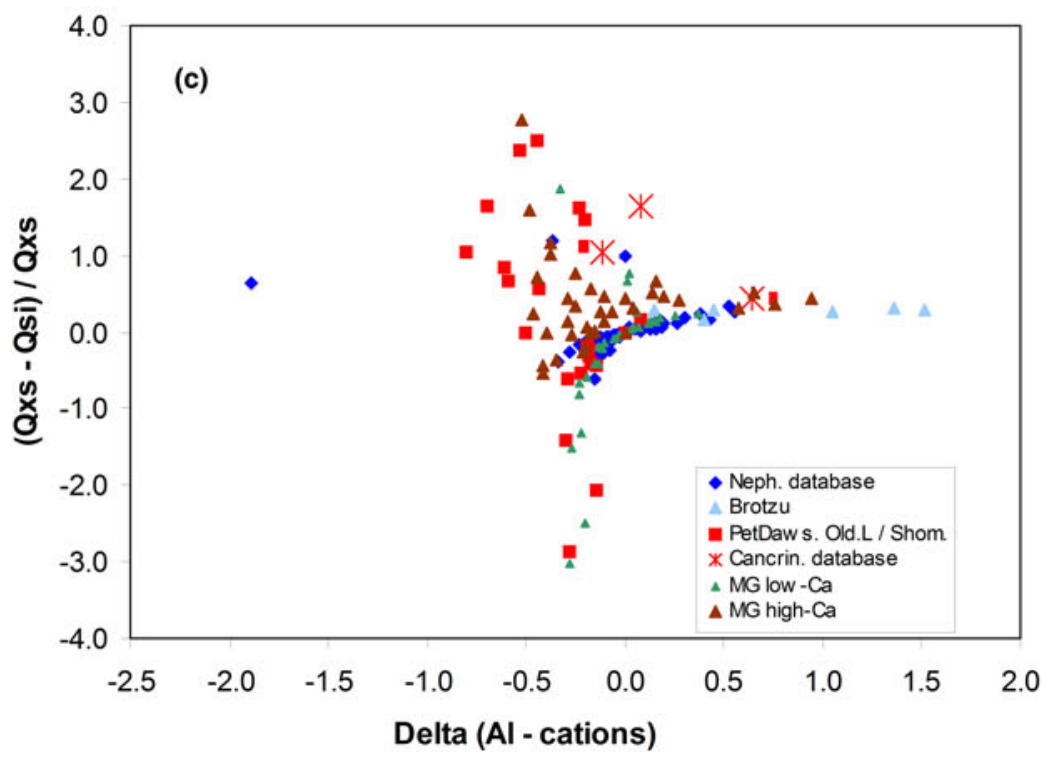


'improvements' result from the model corrections made to subtract the excess $\mathrm{Na}^{\mathrm{xs}}$ or excess $\mathrm{Cn}$ contents; both of these can be considered to be non-nepheline components. However, these are model values and time will tell how useful they are. The $\mathrm{Ne}-\mathrm{Ks}-\mathrm{Q}$ ' percentages for the new calculations are given at the bottom of Table 4 together with the estimated amounts for a possible hydroxycancrinite component; these values are most useful for the most alkali-rich compositions from Oldoinyo-Lengai and Shombole ultra-alkaline volcanic and related rocks where they suggest the presence of $\sim 5 \%$ cancrinite component that matches the earlier estimates. This 'corrected' dataset gives very similar Ks values and the Ne values are within $1-2 \%$ of the previously adopted values in Table 4 with no consistent pattern of the differences being consistently higher or lower; in any case, $1-2 \%$ differences on total Ne contents of 75 to $80 \%$ is the expected analytical error. However, the Q' differences of $\sim 0.5$ to $2 \%$ on a Q content $<5 \%$ is a more serious error. Individual authors would need to decide which calculation protocol would be the most reliable. To support this initiative an EXCEL file is supplied with the Supplementary material to expedite and standardise these calculations, which researchers can download and utilise.

\section{Conclusions}

Molecular proportions for nepheline solid solutions have been calculated on a 32 oxygen unit-cell basis and on end-members of formulae $\mathrm{Na}_{8} \mathrm{Al}_{8} \mathrm{Si}_{8} \mathrm{O}_{32}(\mathrm{Ne}), \mathrm{K}_{8} \mathrm{Al}_{8} \mathrm{Si}_{8} \mathrm{O}_{32}$ (Ks), $\square_{4} \mathrm{Ca}_{4} \mathrm{Al}_{8} \mathrm{Si}_{8}$ $\mathrm{O}_{32}(\mathrm{CaNe})$, and $\square_{8} \mathrm{Si}_{16} \mathrm{O}_{32}\left(\mathrm{Q}^{\mathrm{xs}}\right)$ where ideal stoichiometry and crystal structure define a unit cell with 16 framework cations and 8 cavity sites. This calculation requires proportions of both filled (Ca) and vacant $\left(\square^{\mathrm{Ca}}\right)$ sites to be included to calculate CaNe and of all the $\square^{\mathrm{Si}}$ sites to calculate $\mathrm{Q}^{\mathrm{xs}}$.

Based on Barth (1963) and following nepheline stoichiometry, molecular proportions of main end-members are initially calculated as follows: $\mathrm{Ne}=3 \times \mathrm{Na} / 24 ; \mathrm{Ks}=3 \times \mathrm{K} / 24 ; \mathrm{CaNe}=6 \times$ $\mathrm{Ca} / 24$; and $\mathrm{Q}^{\mathrm{xs}}=(24-3 \mathrm{Na}-3 \mathrm{~K}-6 \mathrm{Ca}) / 24$. Alternative ways of calculating the excess $\mathrm{Si}$ end-member are: $\mathrm{Q}^{\mathrm{Si}}=\mathrm{Si}^{\mathrm{xs}}$ / 16; $\mathrm{Q}^{\text {cavity }}=\left(24-\right.$ total $\left.\mathrm{Si}-\mathrm{Al}-\mathrm{Fe}^{3+}-\mathrm{Na}-\mathrm{K}-2 \mathrm{Ca}\right) / 8$ and $\mathrm{Q}^{(\mathrm{Si}-\mathrm{Al})}=\left(\mathrm{Si}^{\text {total }}-\mathrm{Al}\right) \times 100 / 16$. High quality analyses of stoichiometric nephelines have closely similar $\mathrm{Q}^{\mathrm{xs}}, \mathrm{Q}^{\mathrm{Si}}, \mathrm{Q}^{\text {cavity }}$ and $\mathrm{Q}^{(\mathrm{Si}-\mathrm{Al})}$ values.

'Stuffed-tridymites' with nepheline/kalsilite-type structures are known with $\mathrm{M}^{2+}+\mathrm{Si}^{4+}$ replacing $2 \mathrm{Al}^{3+}$ in the tetrahedral framework are also known with $M=\mathrm{Mg}, \mathrm{Fe}^{2+}, \mathrm{Co}, \mathrm{Zn}$ (Roedder, 1951, 1952; Liu and Barbier, 1993). High quality microprobe analyses with minor amounts of $\mathrm{Mg}$ and $\mathrm{Mn}$ are also known and could form small amounts of the kalsilite analogue $\mathrm{KM}_{0.5}^{2+} \mathrm{Si}_{1.5} \mathrm{O}_{4}$. Such a component is calculated as $\mathrm{Ks} M=6 \times M$ atoms per $32 \mathrm{O} / 24$.

A database of 310 published microprobe nepheline analyses is used to assess the criteria for acceptability of analytical data. Departures from stoichiometry are assessed using the parameters $\Delta \mathrm{Al}^{\mathrm{cc}}$ and $\Delta \mathrm{T}^{\text {charge }}$. The values for these parameters are closely coupled for reliable analyses and acceptable analyses are defined as having values within \pm 0.6 for both $\Delta \mathrm{Al}^{\mathrm{cc}}$ and $\Delta \mathrm{T}^{\text {charge }}$ parameters, and within the range 1.0 to 1.25 for the coupled $\Delta \mathrm{Al}^{\mathrm{cc}}$ / $\mathrm{T}^{\text {charge }}$ ratio. Many high quality nepheline analyses have $\Delta \mathrm{Al}^{\mathrm{cc}}$ / $\mathrm{T}^{\text {charge }}$ values of $\sim 1.134$.

Other criteria used to select reliable analyses are that the $\mathrm{CaO}$ concentrations should be $<3.5$ wt.\%; that $32 \mathrm{O}$ cell formulae should have tetrahedral atom totals within the range 15.9-16.1; and also should show only limited differences between excess $\mathrm{Q}^{\mathrm{xs}}, \mathrm{Q}^{\mathrm{Si}}, \mathrm{Q}^{\text {cavity }}$ and $\mathrm{Q}^{(\mathrm{Si}-\mathrm{Al})}$ parameters.
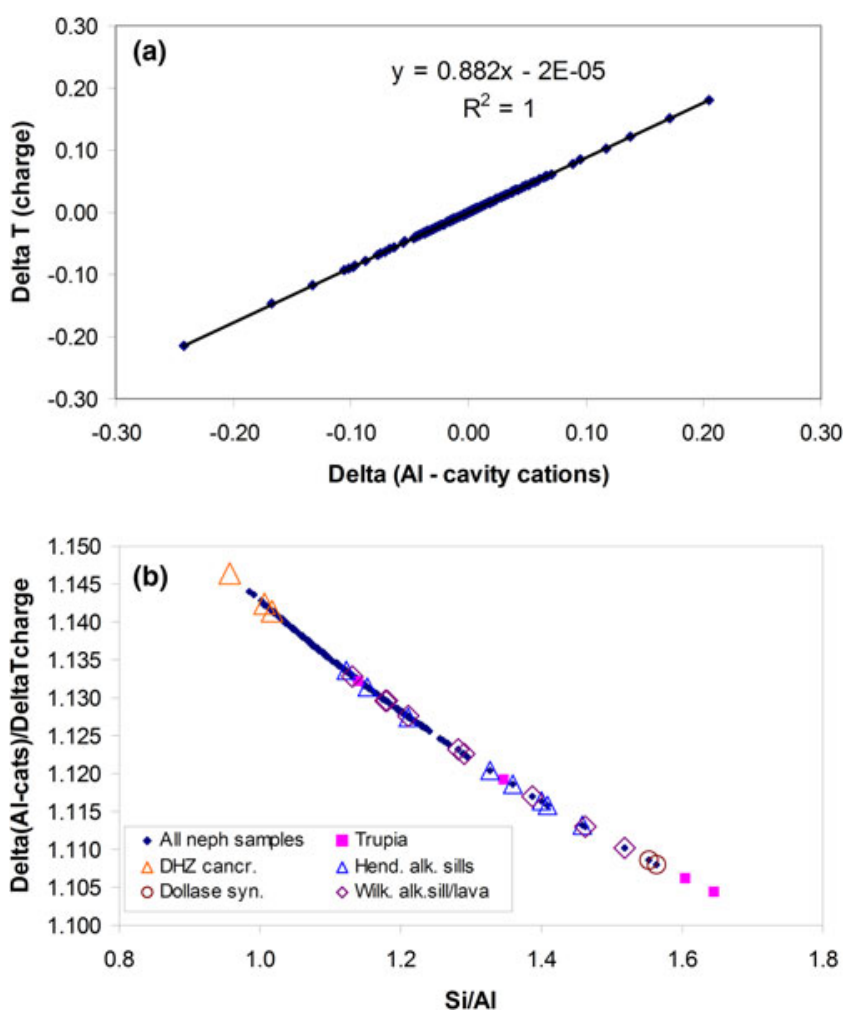

Fig. 6. Plots of compositions for the full database of published nepheline analyses after correcting for the presence of excess $\mathrm{Na}$ or excess $\mathrm{Al}$; see text for procedure. (a) $\Delta \mathrm{T}^{\text {charge }}$ vs. $\Delta \mathrm{Al}^{\mathrm{cc}}$. (b) $\Delta \mathrm{Al}^{\mathrm{cc}} / \Delta \mathrm{T}^{\text {charge }}$ vs. Si/Al. All of the database samples now fall on smooth trends in both figures. Database cancrinite compositions plot at the low $\mathrm{Si} / \mathrm{Al}$ end of the curved trend in $(b)$ and synthetic silica-rich nephelines (Dollase), natural Si-rich nephelines from fast-cooled alkali basaltic sills and lavas (Henderson, Wilkinson), and groundmass samples (Trupia) define the extension to the high $\mathrm{Si} / \mathrm{Al}$ ratios. See text for further explanation.

Good analyses of nepheline phenocrysts from nephelinites and peralkaline igneous rocks associated with $\mathrm{Na}$-rich carbonatites commonly show $\mathrm{Al}$ deficiencies reflected in negative $\Delta \mathrm{Al}^{c \mathrm{cc}}$ parameters, (i.e. negative 'normative' corundum, $\mathrm{Al}_{2} \mathrm{O}_{3}$ ), and anomalously low or negative excess $\mathrm{Q}$ parameters. The relatively low $\mathrm{Al}$ and $\mathrm{Si}$ and high $\mathrm{Na}$ (also perhaps $\mathrm{Ca}$ ) contents suggest the presence of a small amount $(\sim 5 \%)$ of cancrinite as an alteration phase or perhaps even in solid solution within the late-magmatic nepheline. For such nephelines the presence of excess cavity cations over $\left(\mathrm{Al}+\mathrm{Fe}^{3+}\right)$ suggests that the $\mathrm{Q}^{(\mathrm{Si}-\mathrm{Al})}$ calculation might provide the most reliable excess silica estimate.

The compositional characteristics of alteration lamellae of Ca-bearing cancrinite present in nepheline phenocrysts in phonolites from the Marangudzi sub-volcanic alkaline complex, Zimbabwe, are used to define the diagnostic parameters for recognising such non-stoichiometry in nepheline. These alteration lamellae have wt.\% $\mathrm{CaO}$ varying from $\sim 3$ to 14 wt.\% with $\mathrm{K} / \mathrm{Na}$ ratios showing little change from the primary nepheline value. The alteration lamellae are believed to have formed during high-temperature deuteric alteration involving hydrothermal fluids rich in $\mathrm{Ca}$ and low in $\mathrm{K}$.

The IMA have recommended that ideal nepheline should be considered as having the formula $\mathrm{Na}_{3} \mathrm{KAl}_{4} \mathrm{Si}_{4} \mathrm{O}_{16}$ (i.e. the so-called Buerger composition) rather than the previously used $\mathrm{NaAlSiO}_{4}$ : this makes sense for natural Na-rich nephelines but all reliably analysed natural nephelines have $\mathrm{Si} / \mathrm{Al}>1$ (cf. the 
Morozewicz formula). In this work we have found an average $\Delta \mathrm{Al}^{\mathrm{cc}} / \Delta \mathrm{T}^{\text {charge }}=1.134 \pm 0.022$. Using the formula deduced to describe the relationship between $\Delta \mathrm{Al}^{\text {cc }} / \Delta \mathrm{T}^{\text {charge }}$ and Si/Al $(\mathrm{Si} /$ $\left.\mathrm{Al}=289.89\left(\Delta \mathrm{Al}^{\mathrm{cc}} / \Delta \mathrm{T}^{\text {charge }}\right)^{2-} 66.84\left(\Delta \mathrm{Al}^{\mathrm{cc}} / \Delta \mathrm{T}^{\text {charge }}\right)+384.44\right)$ the average $\mathrm{Si} / \mathrm{Al}$ ratio for the natural nepheline database described here would be 1.167 . This ratio together with retaining a $\mathrm{Na} / \mathrm{K}$ ratio of 3 (see above) would give an 'ideal' formula for natural nephelines of $\mathrm{Na}_{2.75} \mathrm{~K}_{0.92} \mathrm{Al}_{3.69} \mathrm{Si}_{4.31} \mathrm{O}_{16}$ assuming strict stoichiometry; note that the mean value calculated for 280 reliable analyses in the current database is $\mathrm{Na}_{2.949} \mathrm{~K}_{0.669} \mathrm{Al}_{3.722} \mathrm{Si}_{4.223}$ that has $\mathrm{Si} / \mathrm{Al}$ $=1.135$ and $\mathrm{Na} / \mathrm{K}=4.41$.

Finally, it is recommended that other researchers should routinely use the approach presented here to recalculate standardised nepheline end-member components. The proportions of the Ca-rich and excess-Si end-member components calculated by different authors would then be directly comparable, allowing magmatic and post-magmatic trends shown by nepheline and associated feldspars to be more easily compared for silica-undersaturated complexes world-wide. An EXCEL file is supplied in the Supplementary material to allow researchers expedite and standardise these calculations.

Acknowledgements. Jack Zussman carefully read the developing text over some time and always gave wise advice and encouragement. Kevin Knight also gave advice throughout and kindly provided the expressions to understand the fundamental significance of the $\Delta \mathrm{Al}^{\mathrm{lc}} / \Delta \mathrm{T}^{\text {charge }}$ ratios. I also thank an anonymous referee and editors Roger Mitchell and Ian Coulson for constructive comments that helped to improve this paper, and also editor Helen Kerbey for her patience.

The enforced closure of the University and the voluntary lockdown at home for four months during the coronavirus epidemic provided the time to go into this topic in an indulgent manner with no time limit.

Supplementary material. To view supplementary material for this article, please visit https://doi.org/10.1180/mgm.2020.78

\section{References}

Andersen T., Elburg M. and Erambert M. (2017) The miaskitic-to-agpaitic transition in peralkaline nepheline syenite (white foyaite) from the Pilanesberg Complex, South Africa. Chemical Geology, 455, 166-181. http://dx-doi.org/10.1016/j.chemgeo.2016.08.020

Antao S.M. and Hassan I. (2010) Nepheline: Structure of three samples from the Bancroft area, Ontario, obtained using synchrotron high-resolution powder X-ray diffraction. The Canadian Mineralogist, 48, 69-80.

Bannister F.A. and Hey M.H. (1931) A chemical, optical and X-ray study of nepheline and kaliophilite. Mineralogical Magazine, 22, 569-608.

Barth T.F.W. (1963) The composition of nepheline. Schweizer Mineralogische Petrologische Mitteilungen, 43, 153-164.

Balassone G. and Beran A. (1995) Variable water content of nepheline from Somma-Vesuvio, Italy. Mineralogy and Petrology, 52, 75-83.

Balassone G., Kahlenberg V., Altomsre A., Mormone A., Rizzi R., Saviano M. and Mondillo N. (2014) Nephelines from the Somma-Vesuvius volcanic complex (Southern Italy): crystal-chemical, structural and genetic investigations. Mineralogy and Petrology, 108, 71-90.

Beran A. (1974) UR-spektroskopischer Nachweis von $\mathrm{H}_{2} \mathrm{O}$ in Nephelin. Tschermaks Mineralogie Petrologie Mitteilungen, 21, 299-304.

Beran A. and Rossman G.R. (1989) The water content of nepheline. Mineralogy and Petrology, 40, 235-240.

Berkesi M., Bali E., Bodnar R.J., Szabó A. and Guzmics T. (2020) Carbonatite and highly peralkaline nephelinite melts from Olodinyo Lengai Volcano, Tanzania. The role of natrite-normative fluid degassing. Gondwana Research, 85, 76-83. https://doi.org/10.1016/j.gr.2020.03.013

Blancher S., D'Arco P., Fonteilles M. and Pascal M.L. (2010) Evolution of nepheline from mafic to highly differentiated members of the alkaline series: the Messum complex, Namibia. Mineralogical Magazine, 74, 413-432.
Bowen N.L. (1912a) The composition of nephelite. American Journal of Science, 33, 49-54.

Bowen N.L. (1912b) The binary system: $\mathrm{Na}_{2} \mathrm{Al}_{2} \mathrm{Si}_{2} \mathrm{O}_{8}$ (nephelite, carnegieite) $\mathrm{CaAl}_{2} \mathrm{Si}_{2} \mathrm{O}_{8}$ (anorthite). American Journal of Science, 33, 551-573.

Brotzu P., Gomes C.B., Melluso L., Morbidelli L., Morra V. and Ruberti E. (1997) Petrogenesis of coexisting $\mathrm{SiO}_{2}$-undersaturated to $\mathrm{SiO}_{2}$-oversaturated felsic igneous rocks: The alkaline complex of Itatiata, southeastern Brazil. Lithos, 40, 133-156.

Buerger M.J. (1954) The stuffed derivatives of the silica structures. American Mineralogist, 39, 600-614.

Chakrabarty A., Mitchell R.H., Ren M., Saha P.K., Pal S., Pruseth K.L. and Sen A.K. (2016) Magmatic, hydrothermal and subsolidus evolution of the agpaitic syenites of the Sushima Hill complex, India: Implications for the metamorphism of peralkaline syenites. Mineralogical Magazine, 80, 11611193. https://doi.org/10.1180/minmag..2016.080.057

Conceição H., Rosa M.deL.daS., Moura C.A.V., Buenano M.J., Macambira M.J.B. and Glazara M.A. (2009) Petrology of the NeoProterozic Itarantim nepheline syenite batholith, Sao Francisco craton, Bahia, Brazil. The Canadian Mineralogist, 47, 1527-1550.

Dawson B.A., Smith J.V. and Steele I.M. (1995) Petrology and mineral chemistry of plutonic igneous xenoliths from the carbonatite volcano, Oldoinyo Lengai, Tanzania. Journal of Petrology, 36, 797-826.

Dawson B.A. and Hill P.G. (1998) Mineral chemistry of a peralkaline combeite-lamprophyllite nephelinite from Oldoinyo-Lengai, Tanzania. Mineralogical Magazine, 62, 179-196.

Deer W.A., Howie R.A. and Zussman J. (1963) Rock-Forming Minerals, Framework Silicates, Volume 4. Longman, London, 435pp.

Deer W.A., Howie R.A. and Zussman J. (1966) An Introduction to the Rock-Forming Minerals. Longman, London. 528 pp.

Deer W.A., Howie R.A. and Zussman J. (1992) An Introduction to the Rock-Forming Minerals, $2^{\text {nd }}$ Edition. Longman, Harlow, Essex, UK, 696pp.

Deer W.A., Howie R.A. and Zussman J. (2004) Rock-Forming Minerals, Framework Silicates: Silica Minerals, Feldspathoids and The Zeolites. Volume $4 B$. The Geological Society, London $982 \mathrm{pp}$.

Deer W.A., Howie R.A. and Zussman J. (2013) An Introduction to the Rock-Forming Minerals, $3^{\text {rd }}$ Edition. The Mineralogical Society, London, 498pp.

Dollase W.A. (1970) Least-squares refinement of the structure of a plutonic nepheline. Zeitschrift Kristallographie, 132, 27-44.

Dollase W.A. (1998) Transformatiosn of the stuffed cristobalites, $\mathrm{K}_{2} \mathrm{MSiO}_{4}, \mathrm{M}$ $=\mathrm{Mg}, \mathrm{Zn}, \mathrm{Co}, \mathrm{Cd}$, with temperature and composition. Physics and Chemistry of Minerals, 25, 389-392.

Dollase W.A. and Peacor D.R. (1971) Si, Al ordering in nephelines. Contributions to Mineralogy and Petrology, 30, 129-134.

Dollase W.A. and Thomas W.M. (1978) The crystal chemistry of silica-rich, alkali-deficient nepheline. Contributions to Mineralogy and Petrology, 66, 311-318.

Donaldson C.H. (1987) The silicate lavas of Oldoinyo Lengai, Tanzania. Neues Jahrbuch Abhandlen, 136, 247-279.

Donnay G., Schairer J.F. and Donnay J.D.H. (1959) Nepheline solid solutions. Mineralogical Magazine, 32, 93-109.

Gibb F.G.F. and Henderson C.M.B. (1978) The petrology of the Dippin sill, Isle of Arran. Scottish Journal of Geology, 14, 1-27.

Edgar A.D. (1964) Studies on cancrinite: II - Stability fields and cell dimensions of calcium and potassium-rich cancrinites. The Canadian Mineralogist, 8, 53-67.

Flohr M.J.K. and Ross M. (1990) Alkaline igneous rocks of Magnet Cove, Arkansas: Mineralogy and geochemistry of syenites. Lithos, 26, 67-98.

Foreman N. and Peacor D.R. (1970) Refinement of the nepheline structure at several temperatures. Zeitschrift fuer Kristallographie, 132, 45-70.

Friese K., Grzechnik A., Petřič V., Schönleber A., van Smaalen S. and Morgenroth W. (2011) Modulated structure of nepheline. Acta Crystallographica, B67, 18-29. doi:// 10.1107/S0108768110050822

Goldsmith J.R. (1949) Some aspects of the system $\mathrm{NaAlSiO}_{4}-\mathrm{CaO} \cdot \mathrm{Al}_{2} \mathrm{O}_{3}$. American Mineralogist, 34, 471-493.

Gregorkiewitz M. (1984) Crystal structure and Al-Si orderingof a synthetic nepheline. Bulletin Mineralogie, 107, 499-507. 
Greig J.W. and Barth T.F.W. (1938) The system $\mathrm{Na}_{2} \mathrm{O} \cdot \mathrm{Al}_{2} \mathrm{O}_{3}-2 \mathrm{SiO}_{2}$ (nephelite, carnegieite) $-\mathrm{Na}_{2} \mathrm{O} \cdot \mathrm{Al}_{2} \mathrm{O}_{3} \cdot 6 \mathrm{SiO}_{2}$ (albite). American Journal of Science, $35 \mathrm{~A}$, 93-112.

Grundy H.D. and Hassan I. (1982) The crystal structure of a carbonate-rich cancrinite. The Canadian Mineralogist, 20, 239-251.

Hahn T. and Buerger M.J. (1955) The detailed structure of nepheline, $\mathrm{KNa}_{3} \mathrm{Al}_{4} \mathrm{Si}_{4} \mathrm{O}_{16}$. Zeitschrift Kristallographie, 106, 308-338.

Hălenius U., Hatert F., Pasero M and Mills S.J. (2018) IMA commission on new minerals, nomenclature and classification (CNMNC). Mineralogical Magazine, 82, 443-451

Hamada M., Akasaka M. and Ohfuji H. (2019) Crystal chemistry of K-rich nepheline in nephelinite from Hamada Shimane Province, Mineralogical Magazine, 83, 239-247.

Hamilton D.L. and MacKenzie W.S. (1960) Nepheline solid solution in the system $\mathrm{NaAlSiO}_{4}-\mathrm{KAlSiO}_{4}-\mathrm{SiO}_{2}$. Journal of Petrology, 1, 56-72.

Hamilton D.L. (1961) Nephelines as crystallization temperature indicators. Journal of Geology, 69, 321-329.

Hassan I. and Grundy H.D. (1984) The character of the cancrinite-vishnevite solid-solution series. The Canadian Mineralogist, 22, 333-340.

Hassan I. and Grundy H.D. (1991) The crystal structure of basic cancrinite, ideally $\mathrm{Na}_{8}\left[\mathrm{Al}_{6} \mathrm{Si}_{6} \mathrm{O}_{24}\right](\mathrm{OH})_{2} \cdot 3 \mathrm{H}_{2} \mathrm{O}$. The Canadian Mineralogist, 29, 377-383.

Hassan I., Antao S.M. and Hersi A.A.M. (2003) Single-crystal XRD, TEM, and thermal studies of the satellite reflections in nepheline. The Canadian Mineralogist, 41, 759-783.

Hayward S.A., Pryde A.K.A., de Dombal R.F., Carpenter M.A. and Dove M.T. (2000) Rigid unit modes in disordered nepheline: a study of a displacive incommensurate phase transition. Physical Chemistry of Minerals, 27, 285-290.

Henderson C.M.B. and Gibb F.G.F. (1972) Plagioclase - Ca-rich nepheline intergrowths in a syenite from the Marangudzi complex, Rhodesia. Mineralogical Magazine, 38, 670-677.

Henderson C.M.B. and Taylor D. (1982) The structural behaviour of the nepheline family: 1 . Sr and $\mathrm{Ba}$ aluminates $\left(\mathrm{MAl}_{2} \mathrm{O}_{4}\right)$, Mineralogical Magazine, 45, 111-127.

Henderson C.M.B. and Gibb F.G.F. (1983) Felsic mineral crystallization trends in differentiating alkaline basic magmas. Contributions to Mineralogy and Petrology, 84, 355-364.

Henderson C.M.B. and Gibb F.G.F. (1987) The petrology of the Lugar sill, S.W. Scotland. Transactions of the Royal Society of Edinburgh, 77, 325-347.

Henderson C.M.B. and Ezepue M.J. (1989) Petrogenesis of the dyke suite from the Marangudzi alkaline igneous ring complex. Zimbabwe. Memoirs Geological Society, India, 15, 83-115.

Henderson C.M.B. and Pierozynski W.J. (2012) An experimental study of Sr, $\mathrm{Ba}$ and $\mathrm{Rb}$ partitioning between alkali feldspar and silicate liquid in the system nepheline-kalsilite-quartz at $0.1 \mathrm{GPa} P\left(\mathrm{H}_{2} \mathrm{O}\right)$. Mineralogical Magazine, 76, 157-190.

Henderson C.M.B., Richardson F.R. and Charnock J.M. (2012) The Highwood Mountains potassic igneous province, Montana; mineral fractionation trends and magmatic processes revisited. Mineralogical Magazine, 76, 1005-1051. https://doi.org/10.1180/minmag.2014.078.1.13

Henderson C.M.B., Pendlebury K. and Foland K.A. (1989) Mineralogy and petrology of the Red Hill alkaline igneous complex, New Hampshire, U.S.A. Journal of Petrology, 30, 627-666.

Henderson C.M.B., Bell A.M.T., Kohn S.C. and Page C.S. (1998) Leucite-pollucite structure-type variability and the structure of a synthetic end-member wairakite $\left(\mathrm{CaAl}_{2} \mathrm{Si}_{4} \mathrm{O}_{12} \mathrm{H}_{2} \mathrm{O}\right)$. Mineralogical Magazine, 62, 165178.

Henderson C.M.B., Hamilton D.L. and Waters J. (2014) Phase equilibria in $\mathrm{NaAlSiO}_{4}-\mathrm{KAlSiO}_{4}-\mathrm{SiO}_{2}-\mathrm{H}_{2} \mathrm{O}$ at $100 \mathrm{MPa}$ pressure: equilibrium leucite compositition and the enigma of primary analcime in blairmorites revisited. Mineralogical Magazine, 78, 171-202.

Henderson C.M.B., Bell A.M.T. and Knight K.S. (2017) Variable stoichiometry in tectosilicates having the leucite-pollucite-type structure with particular emphasis on modelling the interframework cavity cation environment. Journal of Solid State Chemistry, 251, 90-104. https://dx.doi.org/10.1016.j. jssc.2017.04.013

Hippler B. and Böhm H. (1989) Structure investigations on sodium nephelines. Zeitschrift Kristallographie, 187, 39-53.
Kohn S.C., Dupree R. and Smith M.E. (1989) A multinuclear nuclear magnetic resonance study of the structure of hydrous albite glasses. Geochimica et Cosmochimica Acta, 53, 2925-2935.

Larsen E.S. and Foshag W.F. (1926) Cancrinite as a high temperature hydrothermal mineral from Colorado. American Mineralogist, 11, 300-303.

Levin I. and Brandon D. (1998) Metastable alumina polymorphs: crystal structures and transition sequences. Journal of the American Ceramic Society, 81, 1995-2012.

Liu B. and Barbier J. (1993) Structures of the stuffed-tridymite derivatives, $\mathrm{BaMSiO}_{4}(M=\mathrm{Co}, \mathrm{Zn}, \mathrm{Mg})$. Journal of Solid State Chemistry, 102, $115-125$.

Mann U., Marks M. and Markl G. (2006) Influence of oxygen fugscity on mineral compositions in peralkaline melts. The Katzenbuckel volcano, Southwest Germany. Lithos, 91, 262-285. doi:10.1016/j.lithos.2005.09.004

McConnell J.D.C. (1962) Electron diffraction study of subsidiary maxima of scattered intensity in nepheline. Mineralogical Magazine, 33, 114-124.

McConnell J.D.C. (1981) Time-temperature study of the intensity of satellite reflections in nepheline. American Mineralogist, 66, 990-996.

McMillan P.F., Jakobsson S., Holloway J.R. and Silver L.A. (1983) A note on the Raman spectra of water-bearing albite glasses. Geochimica et Cosmochimica Acta, 47, 1937-1943.

Melluso L., Morra V., and Girolamo P.Di (1996) The Mt. Vulture volvanic complex (Italy): evidence for distinct parental magmas and for residual melts with melilite. Mineralogy and Petrology, 56, 225-250.

Melluso L., Srivastava R.K., Petrone C.M., Guarino V., and Sinha A.K. (2012) Mineralogy and magmatic affinity of the Jasra intrusive complex, Shillong Plateau, India. Mineralogical Magazine, 76, 1099-1117. DOI:// 10.1180/ minmag.2012.076.5.03

Mitchell R.H. and Platt R.G. (1979a) Nepheline - plagioclase intergrowths of metasomatic origin from the Coldwell Complex, Ontario. The Canadian Mineralogist, 17, 537-540.

Mitchell R.H. and Platt R.G. (1979b) Nepheline-bearing rocks from the Poobah Lake Complex, Ontario: Malignites and malignites. Contributions to Mineralogy and Petrology, 69, 255-264.

Mitchell R.H. and Platt R.G. (1982) Mineralogy and petrology of nepheline syenites from the Coldwell Alkaline Complex, Ontario, Canada. Journal of Petrology, 23, 186-214.

Möller V. and William-Jones A.E. (2016) Petrogenesis of the Nechalacho Layered Suite, Canada: magmatic evolution of a REE-Nb-rich nepheline syenite intrusion. Journal of Petrology, 57, 229-276. doi:// 10.1093/petrology/egw003

Moreau C., Ohnenstetter D., Demaiffe D. and Robineau B. (1996) The Los Archipelago nepheline syenite ring-structure: a magmatic marker of the evolution of the Central and Equatorial Atlantic. The Canadian Mineralogist, 34, 281-299.

Morgan G.B. VI and London D. (2005) Effect of current density on the electron microprobe analysis of alkali aluminosilicate glasses. American Mineralogist, 90, 1131-1138.

Morozewicz J. (1930) Der Mariupolit und seine Blutsverwandten. Tschermaks mineralogische und petrographische Mitteilungen, 40, 335-436.

Okumiya M. and Yamaguchi G. (1971) The crystal structure of $\kappa^{\prime}-\mathrm{Al}_{2} \mathrm{O}_{3}$, the new intermediate phase. Bulletin Chemical Society Japan, 44, 15671570.

Parker J.M. (1972) The domain structure of nepheline. Zeitschrift Kristallographie, 136, 255-272.

Paslick C.R., Halliday A.N., Lange R.A., James D. and Dawson J.B. (1996) Indirect crustal contamination: evidence from isotoplc and chemical disequilibria from alkali basalts and nephelinites from northern Tanzania. Contributions to Mineralogy and Petrology, 125, 277-292.

Peterson T.D. (1989) Peralkaline nephelinites. 1. Comparative petrology of Shombole and Oldoinyo Lengai, East Africa. Contributions to Mineralogy and Petrology, 101, 458-478.

Rock N.M.S. (1978) Petrology and petrogenesis of the Monchique alkaline complex, southern Portugal. Journal of Petrology, 19, 171-214.

Roedder E.W. (1951) The system $\mathrm{K}_{2} \mathrm{O}-\mathrm{MgO}-\mathrm{SiO}_{2}$. American Journal of Science, 249, 81-130 and 224-248.

Roedder E. (1952) A reconnaissance of the liquidus relationships in the system $\mathrm{K}_{2} \mathrm{O} .2 \mathrm{SiO}_{2}-\mathrm{FeO}-\mathrm{SiO}_{2}$. American Journal of Science, (Bowen volume), 250A, 435-456. 
Roedder E. (1978) Silicate liquid immiscibility in magmas and in the system $\mathrm{K}_{2} \mathrm{O}-\mathrm{FeO}-\mathrm{Al}_{2} \mathrm{O}_{3}-\mathrm{SiO}_{2}$ : an example of serendipity. Geochimica et Cosmochimica Acta, 42, 1597-1617.

Rossi G., Oberti R. and Smith D.C. (1989) The crystal structure of a K-poor, Ca-rich silicate with the nepheline framework, and crystal-chemical relationships in the compositional space $(\mathrm{K}, \mathrm{Na}, \mathrm{Ca}, \square)_{8}(\mathrm{Al}, \mathrm{Si})_{16} \mathrm{O}_{32}$. European Journal of Mineralogy, 1, 59-70.

Roux J. (1974) Etude des solutions solides des néphélines (Na,K) $\mathrm{AlSiO}_{4}$ et (Na,Rb) $\mathrm{AlSiO}_{4}$ ) Geochimica et Cosmochimica Acta, 38, 1213-1224.

Sahama Th. G. (1958) A complex form of natural nepheline from Iivaara, Finland. American Mineralogist, 43, 165-155.

Schairer J.F. and Bowen N.L. (1935) Preliminary report on equilibrium relations between feldspathoids, alkali feldspars and silica. American Geophysical Union Transactions, 325-328.

Simakin A.G., Salova T.P. and Zavel'skii V.O. (2008) Incorporation of water in the structure of nepheline from the data of NMR and IR spectrometry. Geochemistry International, 46, 622-626.

Simmons W.B. and Peacor D.R. (1972) Refinement of the crystal structure of a volcanic nepheline. American Mineralogist, 57, 1711-1719.

Sirbescu M. and Jenkins D.M. (1999) Experiments on the stability of cancrinite in the system $\mathrm{Na}_{2} \mathrm{O}-\mathrm{CaO}-\mathrm{Al}_{2} \mathrm{O}_{3}-\mathrm{SiO}_{2}-\mathrm{CO}_{2}-\mathrm{H}_{2} \mathrm{O}$. American Mineralogist, 84, 1850-1860.

Smith J.V. and Sahama Th.G. (1954) Determination of the composition of natural nephelines by an X-ray method. Mineralogical Magazine, 30, 439-449.

Smith J.V. and Tuttle O.F. (1957) The nepheline-kalsilite system: I. X-ray data for the crystalline phases. American Journal of Science, 255, 282-305.

Stolper E. (1982) Water in silicate glasses: An infrared spectroscopic study. Contributions to Mineralogy and Petrology, 81, 1-17.

Tait K.T., Sokolova E., Hawthorne F.C. and Khomyakov A.P. (2003) The crystal chemistry of nepheline. The Canadian Mineralogist, 41, 61-70.

Tilley C.E. (1954) Nepheline-alkali feldspar parageneses. American Journal of Science, 252, 65-75.

Tilley C.E. (1958) The leucite nepheline dolerite of Meiches, Vogelsberg, Hessen. American Mineralogist, 43, 758-761.

Tilley C.E. and Gittins J. (1961) Igneous nepheline-bearing rocks of the Haliburton-Bancroft province of Ontario. Journal of Petrology, 2, 38-48.

Torres-Martinez L.M. and West A.R. (1989) Pollucite- and leucite-related phases: $\mathrm{A}_{2} \mathrm{BX}_{5} \mathrm{O}_{12}$ and $\mathrm{ACX}_{2} \mathrm{O}_{6}(\mathrm{~A}=\mathrm{K}, \mathrm{Rb}, \mathrm{Cs} ; \mathrm{B}=\mathrm{Be}, \mathrm{Mg}, \mathrm{Fe}, \mathrm{Co}, \mathrm{Ni}, \mathrm{Zn}, \mathrm{Cd}$; $\mathrm{C}=\mathrm{B}, \mathrm{Al}, \mathrm{Ga}, \mathrm{Fe}, \mathrm{Cr} ; \mathrm{X}=\mathrm{Si}, \mathrm{Ge})$. Zeitschrift für anorganische und allgemeine Chemie, 573, 223-230.
Trupia S. and Nicholls J. (1996) Petrology of recent lave flows, Volcano Mountain, Yukon, Territory, Canada. Lithos, 37, 61-78.

Valentin E., Botelho N. and Dantas E.L. (2020) Monte Santo suite, an example of Ediacaran-Cambrian deformed alkaline rocks in the Arguaia Belt Implications for Western Gondwana evolution. Lithos, 366-367, 105552. https://doi.org/10.1016/j.lithos.2020.105552

Ventura G.D., Bellatreccia F., Parodi G.C., Camara F. and Piccinini M. (2007) Single-crystal FTIR and X-ray study of vishnevite, ideally $\left[\mathrm{Na}_{6}\left(\mathrm{SO}_{4}\right)\right]$ $\left[\mathrm{Na}_{6}\left(\mathrm{H}_{2} \mathrm{O}\right)_{2}\right]\left(\mathrm{Si}_{6} \mathrm{Al}_{6} \mathrm{O}_{24}\right)$. American Mineralogist, 92, 713-721.

Vrublevskii V.V., Nikiforov A.V., Sugorakova A.M. and Kozulina T.V. (2020) Petrogenesis and tectonic setting of the Cambrian Kharly alkalinecarbonatite complex (Sangilen Plateau, Southern Siberia): Implications for the Early Paleozoic evolution of magmatism in the western Central Asian Orogenic Belt. Journal of Asian Earth Sciences, 188, 104163. https://doi. org/10.1016/j.jseaes.2019.104163

Vulić P., Balić-Žunić T., Belmonte L.J. and Kahlenberg V. (2011) Crystal chemistry of nephelines from ijolites and nepheline-rich pegmatites: influence of composition and genesis on the crystal structure investigated by X-ray diffraction. Mineralogy and Petrology, 101, 185-194.

Wilkinson J.F.G. (1965) Some feldspars, nephelines and analcimes from the Square Top intrusion, Nundle, N.S.W. Journal of Petrology, 6, 420-444.

Wilkinson J.F.G. and Stolz A.J. (1983) Low-pressure fractionation of strongly undersaturated alkaline ultrabasic magma: the olivine-melilite-nephelinite at Moiliili, Oahu, Hawaii. Contributions to Mineralogy and Petrology, 83, 363-374.

Wilkinson J.F.G. and Hensel H.D. (1994) Nephelines and analcimes in some alkaline igneous rocks. Contributions to Mineralogy and Petrology, 118, 79-91.

Wittke J.H. and Holm R.E. (1996) The association basanitic nephelinite - feldspar ijolite - nepheline monzonite at House Mountain volcano, North-Central, Arizona. The Canadian Mineralogist, 34, 221-240.

Worley B.A. and Cooper A.F. (1995) Mineralogy of the Dismal nepheline syenite, Southern Victoria Land, Antarctica. Lithos, 35, 109-128.

Yesinowski J.P., Eckert H. and Rossman G.R. (1988) Characterization of hydrous species in minerals by high-speed ${ }^{1} \mathrm{H}$ MAS-NMR. Journal of the American Ceramic Society, 110, 1367-1375.

Zhu Y.-S., Yang J.-H., Sun J.-H., Zhang J-H. and Wu F.Y. (2016) Petrogenesis of coeval silica-saturated and silica-undersaturated alkaline rocks: Mineralogical and geochemical evidence from the Saima alkaline complex, N.E. China. Journal Asian Earth Sciences, 117, 184-207, https://dx.doi.org/ 10.1016/j.jseaes.2015.12.014 